\title{
Independent Technical Evaluation and Recommendations for Contaminated Groundwater at the Department of Energy Office of Legacy Management Riverton Processing Site
}

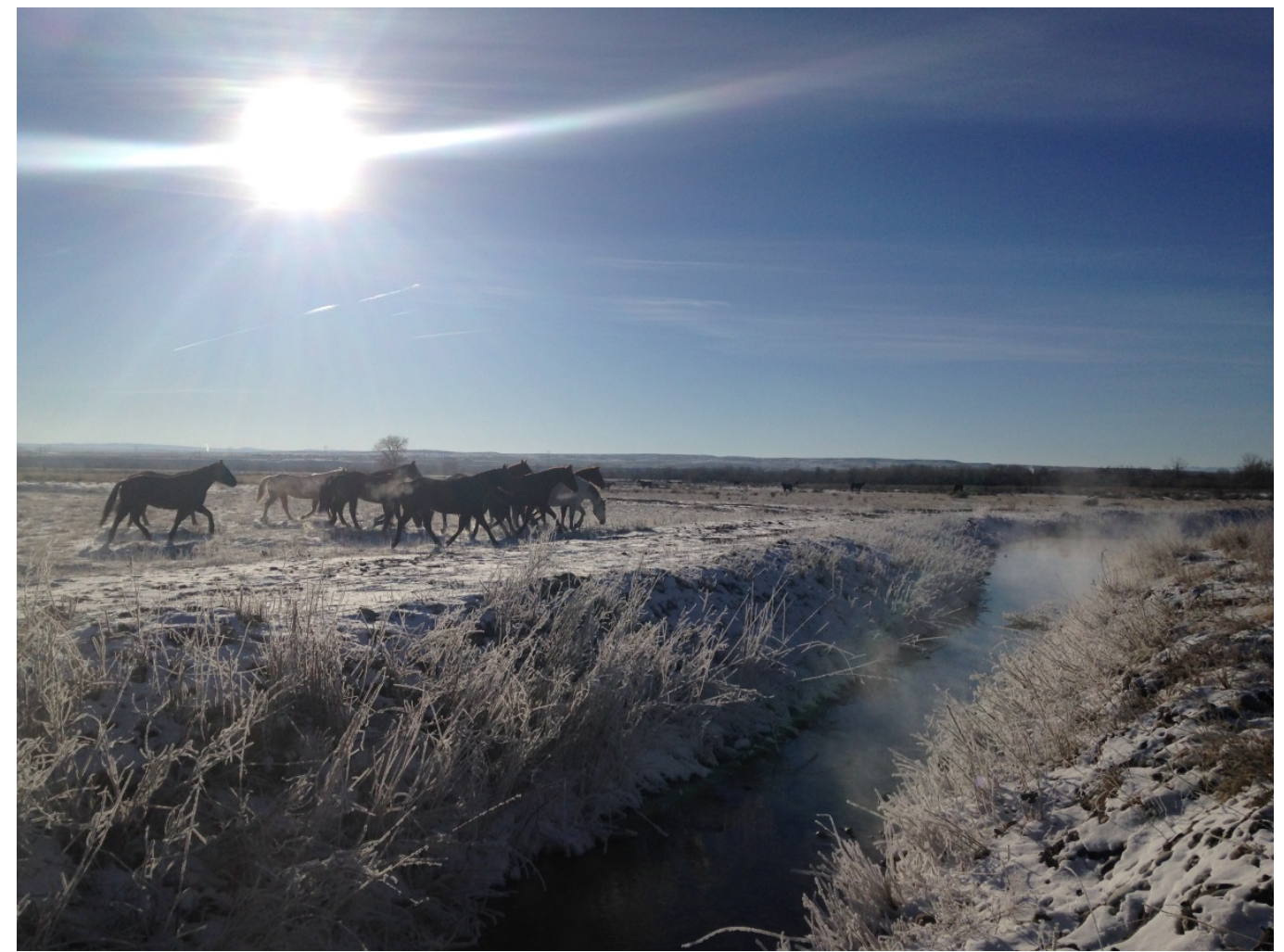

April 2014

Prepared for: The U.S. Department of Energy (DOE) Office of Legacy Management (LM) Prepared by: The DOE EM Center for Sustainable Groundwater and Soil Solutions, Savannah River National Laboratory, Aiken SC

Technical content and coordination for this effort was provided by the Savannah River National Laboratory in conjunction with Contract No. DE-AC09-08SR22470 with the U.S. Department of Energy. 

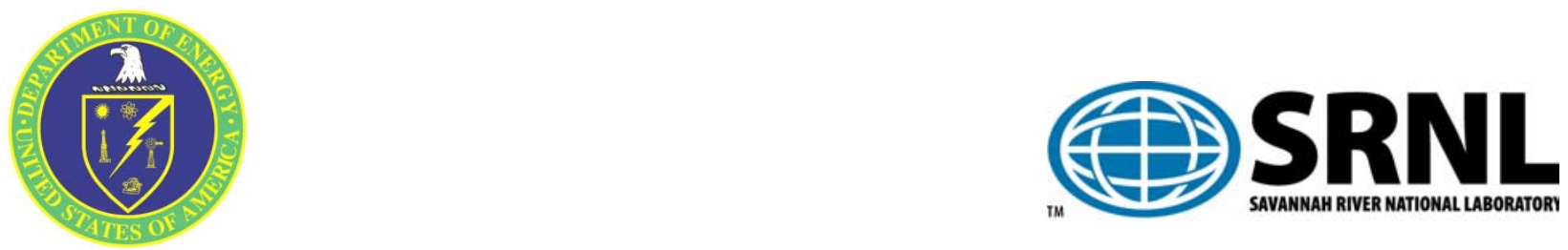

\section{Cover Photo: Horses grazing at the Riverton, WY, Processing Site during the site visit in December 2013}

\section{DISCLAIMER}

This work was prepared under an agreement with and funded by the U.S. Government. While the authors have taken care in the preparation of this report, neither the U. S. Government or its employees, nor any of its contractors, subcontractors or their employees, makes any express or implied: 1 . warranty or assumes any legal liability for the accuracy, completeness, or for the use or results of such use of any information, product, or process disclosed; or 2. representation that such use or results of such use would not infringe privately owned rights; or 3. endorsement or recommendation of any specifically identified commercial product, process, or service. Any views and opinions of authors expressed in this work do not necessarily state or reflect those of the United States Government, or its contractors, or subcontractors. 


\title{
Independent Technical Evaluation and Recommendations for Contaminated Groundwater at the Department of Energy Office of Legacy Management Riverton Processing Site
}

\author{
Authors: \\ Brian B. Looney, Savannah River National Laboratory \\ Miles E. Denham, Savannah River National Laboratory \\ Carol A. Eddy-Dilek, Savannah River National Laboratory \\ Prepared for \\ U.S. Department of Energy Office of Legacy Management
}

April 2014

Technical content and coordination for this effort was provided by the Savannah River National Laboratory in conjunction with Contract No. DE-AC09-08SR22470 with the U.S. Department of Energy. 


\section{Table of Contents}

Executive Summary ................................................................................................................................ 1

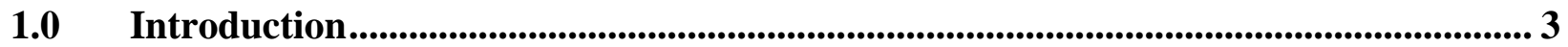

Background and Objectives .................................................................................... 3

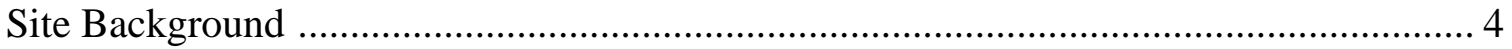

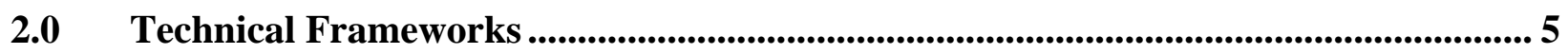

Introduction to the Framework Concept ……………………………………………..... 5

Spatial/Temporal Frameworks................................................................................... 6

Hydrological and Geochemical Frameworks - A Preliminary Conceptual Model ............. 8

Hydrological Conceptual Framework................................................................................. 12

Hydrological Conceptual Framework Continued - Scoping Evaluation of

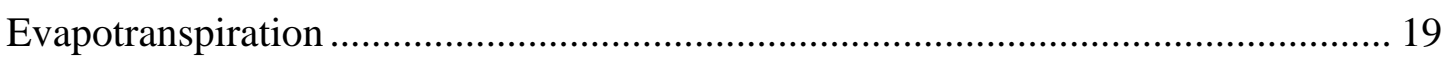

Geochemical Framework for Uranium Milling and Tailings Disposal Sites .................... 26

Interactions of the Frameworks ...................................................................................... 50

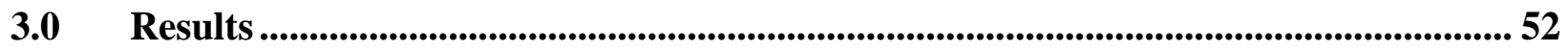

Challenges and Opportunities Identified in the Framework Evaluation............................. 52

Data Gaps and Recommended Characterization Activities to Resolve Uncertainties...... 52

Evaluation of Legacy Management Options........................................................................ 54

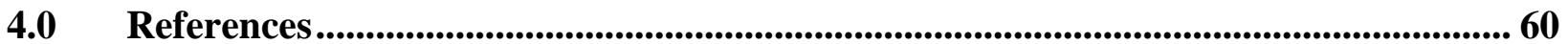

\section{Appendices}

Appendix A

Appendix B

Appendix C
Statement of Work

Technical Team Biographies

Review of 2102 Enhanced Characterization Report 


\section{List of Figures}

Figure 1 Useful technical frameworks that support optimized environmental and legacy management decisions 6

Figure 2 Simplified conceptualization of facility impacts on the surrounding environment and technology matching principles. 7

Figure 3 Key geochemical processes associated with non-pedogenic mineral accumulations in arid and semi-arid settings 10

Figure $4 \quad$ Flora observed (photos from December 2013) in lands overlaying the groundwater plume downgradient of the Riverton Processing Site.

Figure 5 General hydrologic setting of the Riverton Processing Site 13

Figure 6 Flow in the Wind River (06228000) and Little Wind River (06235500) at the USGS gauging stations near Riverton WY, Mar 20 - Apr 8, 2014

Figure $7 \quad$ Natural flow gradients between the Wind River and Little Wind River near the Riverton Processing Site, Riverton WY 14

Figure 8 Areas where irrigation ditches are present (shaded) and qualitative influence of irrigation on groundwater flow direction in the surficial aquifer (arrows) 15

Figure 9

Figure 10 Hydrologic impacts of tailings disposal (1958-1963) 16

Figure 11 Satellite image of the Little Wind River near the Riverton Processing Site 18 Groundwater wells in the vicinity of the Riverton Processing Site instrumented with water level transducers and data loggers 19

Figure 12 Traditional hydrograph showing water levels in selected wells over a 10 month period 20

Figure 13 Hydrograph showing the diurnal variation 21

Figure 14

Figure 15 Estimation of ETg from hydrograph from well 707 (09/03/2012 through 09/04/2012) using the White (1932) Method and a Modified Method Seasonal hydrographs from well 707 annotated with the approximate diurnal piezometric surface variation for the periods depicted 24

Figure 16 Summer hydrographs from instrumented wells in the surficial aquifer near the Riverton Processing Site annotated with the approximate diurnal piezometric surface variation 25

Figure 17 Simulation of the effect of $\mathrm{CO}_{2}$ degassing on uranium mineral saturation indices using an initial groundwater composition from well $0789 \quad 28$

Figure 18 Simulation of evaporation of water from well 0789; A) first $90 \%$ of evaporation, B) final $1 \%$ of evaporation 29

Figure 19

Figure 20

Figure 21

Plot of sodium versus calcium in groundwater from the Riverton site 30 Plot of sodium versus sulfate in groundwater from the Riverton site Diagram of lithologic facies associated with a cut off meander on the Mississippi River 32

Figure 22 Satellite image of the Riverton Site 33

Figure 23

Figure 24

Figure 25 Saturation indices $(\log \mathrm{Q} / \mathrm{K})$ for calcite and gypsum in groundwater at the Riverton site $\quad 34$ Partial Pressure of $\mathrm{CO}_{2}$ versus sulfate in Riverton site groundwater 35 Eh-pH diagram of iron speciation showing Eh-pH values for Riverton site groundwater $($ triangles $=$ well data, closed circles $=$ GeoProbe data) 35 
Figure 26 Time trends for water table elevation, uranium, molybdenum, and sulfate in well $0707 \quad 37$

Figure 27 Time trends for water table elevation, uranium, molybdenum, and sulfate in well $0789 \quad 38$

Figure 28 Time trend of specific conductance in well 0707 39

Figure 29 Photographs of white evaporite mineral deposits observed along the escarpment at the Little Wind River 40

Figure $30 \quad \mathrm{XRD}$ results identifying the major minerals present in the Riverton WY evaporite scoping sample collected from the escarpment near well $789 \quad 42$

Figure $31 \quad$ Eh-pH diagram of molybdenum speciation with sulfur present $\quad 44$

Figure 32 Activity-activity diagrams showing stability of soddyite (A) and carnotite (B) relative to compositions of Riverton site groundwater 45

Figure 33 Eh-pH diagram showing speciation of uranium and stability of reduced uranium minerals relative to Riverton site groundwater compositions. $\quad 46$

Figure 34 Ternary diagram of major cation composition of groundwater and water from the sulfuric acid plant ditch $\quad 47$

Figure $35 \quad$ Locations of GeoProbe groundwater samples 48

Figure 36 Magnesium versus sulfate concentrations in GeoProbe groundwater samples; red circles mark those near the effluent ditch $\quad 49$

Figure 37 Simplified depiction detailing some of the key features of the Riverton landscape in the mid-field plume and near the Little Wind River outcrop area 50

Figure $38 \quad$ Site specific spatial framework 51

Figure 39 Key patterns of projected mineral and uranium accumulation $\quad 53$

\section{List of Tables}

Table 1 Summary of ET $_{\mathrm{g}}$ scoping estimates based on hydrographs of instrumented wells near the Riverton Processing Site 26

Table 2 Chemical composition (XRF data) of the bulk Riverton WY evaporite scoping sample collected from the escarpment near well 789

Table 3 Mineralogical composition (XRD and combined XRD-XRF) of the Riverton WY evaporite scoping sample collected from the escarpment near well $789 \quad 43$

Table 4 Example Technologies -- legacy management options related to contaminated groundwater near the Riverton Processing Site 57 


\section{Executive Summary}

The U.S. Department of Energy Office of Legacy Management (DOE-LM) manages the legacy contamination at the Riverton, WY, Processing Site - a former uranium milling site that operated from 1958 to 1963 . The tailings and associated materials were removed in 1988-1989 and contaminants are currently flushing from the groundwater.

DOE-LM commissioned an independent technical team to assess the status of the contaminant flushing, identify any issues or opportunities for DOE-LM, and provide key recommendations.

The team applied a range of technical frameworks - spatial, temporal, hydrological and geochemical - in performing the evaluation. In each topic area, an in depth evaluation was performed using DOE-LM site data (e.g., chemical measurements in groundwater, surface water and soil, water levels, and historical records) along with information collected during the December 2013 site visit (e.g., plant type survey, geomorphology, and minerals that were observed, collected and evaluated). A few of the key findings include:

- Physical removal of the tailings and associated materials reduced contaminant discharges to groundwater and reduced contaminant concentrations in the near-field plume.

- In the mid-field and far-field areas, residual contaminants are present in the vadose zone as a result of a variety of factors (e.g., evaporation/evapotranspiration from the capillary fringe and water table, higher water levels during tailings disposal, and geochemical processes).

- Vadose zone contaminants are widely distributed above the plume and are expected to be present as solid phase minerals that can serve as "secondary sources" to the underlying groundwater. The mineral sample collected at the site is consistent with thermodynamic predictions.

- Water table fluctuations, irrigation, infiltration and flooding will episodically solubilize some of the vadose zone secondary source materials and release contaminants to the groundwater for continued down gradient migration - extending the overall timeframe for flushing.

- Vertical contaminant stratification in the vadose zone and surficial aquifer will vary from location to location. Soil and water sampling strategies and monitoring well construction details will influence characterization and monitoring data.

- Water flows from the Wind River, beneath the Riverton Processing Site and through the plume toward the Little Wind River. This base flow pattern is influenced by seasonal irrigation and other anthropogenic activities, and by natural perturbations (e.g., flooding). 
- Erosion and reworking of the sediments adjacent to the Little Wind River results in high heterogeneity and complex flow and geochemistry. Water flowing into oxbow lakes (or through areas where oxbow lakes were present in the past) will be exposed to localized geochemical conditions that favor chemical reduction (i.e., "naturally reduced zones”) and other attenuation processes. This attenuation is not sufficient to fully stabilize the plume or to reduce contaminant concentrations in the groundwater to target levels.

Consistent with these observations, the team recommended increased emphasis on collecting data in the zones where secondary source minerals are projected to accumulate (e.g., just above the water table) using low cost methods such as x-ray fluorescence. The team also suggested several low cost nontraditional sources of data that have the potential to provide supplemental data (e.g., multispectral satellite imagery) to inform and improve legacy management decisions.

There are a range of strategies for management of the legacy contamination in the groundwater and vadose zone near the Riverton Processing Site. These range from the current strategy, natural flushing, to intrusive remedies such as plume scale excavation of the vadose zone and pump \& treat. Each option relates to the site specific conditions, issues and opportunities in a unique way. Further, each option has advantages and disadvantages that need to be weighed. Scoping evaluation was performed for three major classes of technologies - contaminant removal technologies, contaminant stabilization technologies, and natural flushing. The intent of the scoping evaluation is to provide an initial set of options for consideration by LM as they finalize plans to address the Riverton groundwater plume. Three technologies were conditionally recommended: 1) continued natural flushing, 2) groundwater pump and treat with plume scale irrigation to help flush out vadose zone contamination, or 3) in situ stabilization using structured geochemical zones to supplement the naturally reduced zones already present at the site. 


\subsection{Introduction}

\section{Background Scope and Objectives}

For over two decades, the Savannah River National Laboratory (SRNL) has managed a Technical Assistance program focused on providing technical support to the larger Department of Energy (DOE) complex. In 2013, the DOE Office of Legacy Management (LM) requested that SRNL provide independent technical experts to evaluate the groundwater conditions and cleanup progress at the former Riverton, WY, Processing Plant. To perform the evaluation, the SRNL applied an overarching set of technical frameworks that focus on the site-specific conditions at former uranium mining and milling sites (Looney, 2013). The individual frameworks included:

1) Spatial Framework - places plume data within the spatial context of the sites from source to plume fringe; different locations within the spatial framework require different approaches to characterization, remediation and monitoring

2) Temporal Framework - relates plume data to events in the history of the site, starting with initiation of the processes that caused contamination to remedial action and recovery

3) Hydrological Framework - relates plume data to the physical forces driving plume movement including boundary conditions such as streams and, in arid climates, the capillary fringe

4) Geochemical Framework - describes the interactions of plume constituents with aquifer materials and uncontaminated groundwater, as well as other geochemical process affecting contaminant migration.

For this effort, the technical team was asked to prepare a report that includes an assessment of the current status of the site in terms of the hydrological and geochemical conditions at Riverton -- similar in nature to the previous evaluation of the Tuba City, AZ, Disposal Site (Looney, 2013). Specifically, the team was asked to address the following recommendation from the Enhanced Characterization Report (DOE, 2013), “Although DOE obtained a better understanding of the site conceptual model, contaminant distributions, and properties of the unsaturated zone for the surficial aquifer at the Riverton site in 2012, additional work is needed to further define the conceptual model, to better understand geochemical processes that control contaminant fate and transport, to identify additional sources of uranium that are liberated during flood events, and to understand why uranium concentrations decline relatively quickly after flood events. This additional information will assist in making decisions for a path-forward compliance strategy.” The following questions were identified:

- What are the key processes controlling contaminant behavior in the groundwater?

- What additional data and models are needed to locate and explain contaminant sources and sinks?

- Should we develop a statistical basis for the sampling grid and data analysis?

- Is the three aquifer groundwater system adequately monitoring for flow and water quality including recharge and discharge areas?

- What tests can be performed to discern between physical (diffusive, hydrologic, advective, and geochemical controls (e.g. sorption, redox) on contaminant migration? 
- What codes and models should be selected/created, and would transient stochastic modeling be useful to provide probability estimates for natural attenuation?

The selected group of technical experts visited the Riverton site processing and storage facilities during December 2013. DOE-LM and contractor personnel briefed the team during the visit. The team reviewed and discussed baseline data and reports with LM and contractor personnel in order to develop a set of overarching recommendations.

\section{Site Background}

The former Riverton Processing Site is in Fremont County, 2 miles (3.2 km) southwest of the town of Riverton, Wyoming between the Little Wind River and Wind River. It is located in the center of the Wind River Basin at an elevation of approximately 5,000 ft (1500 m) above mean sea level (msl). Riverton has semi-arid climate characterized by cold, dry winters and warm, slightly wetter summers. Average rainfall is estimated at 7 to 9 inches/yr (175 to $230 \mathrm{~mm} / \mathrm{yr}$ ). The former processing site is located within the boundaries of the Wind River Indian Reservation (Northern Arapaho and Eastern Shoshone) on property now owned by Chemtrade Refinery Services.

The site is the location of a former uranium and vanadium-ore processing mill that operated from 1958 to 1963. Past milling operations created radioactive mill tailings, a predominantly sandy material, and uranium, radium, and thorium contamination in soils and construction debris. A tailings pile covered about half of the 140-acre site. In 1988, about 1.8 million cubic yards of the contaminated materials were removed from the site and relocated to the Gas Hills East disposal site 45 miles away. The U.S. Department of Energy (DOE) completed surface remediation of the Riverton site in 1989. Milling operations at the site caused both surface and groundwater contamination. 


\subsection{Technical Frameworks}

\section{Introduction to the Framework Concept}

In evaluating the available data for the Riverton Processing Site, the team first developed an overarching set of specific technical frameworks. The proposed frameworks are integrated with existing conceptual models/approaches that already have been developed for the site. The overall objective of this effort was to identify scientific and technical areas of opportunity for the DOE-LM program, specific to the Riverton Site.

Development of technical frameworks is a key strategy to apply basic science to an applied field problem. When directed toward understanding complex real-world environmental remediation challenges, frameworks are tools that support practical identification and incorporation of the key-controlling scientific processes and principles. Technical frameworks provide a consistent way of organizing and interpreting complex data in a manner that supports environmental decision making. Technical frameworks capture key features at a site in an intuitive manner that supports a practical and actionable understanding. Technical frameworks can be used to minimize technical risks, encourage efficiency and effectiveness, and provide the basis for innovative and creative solutions.

Figure 1 depicts several technical frameworks that have proven useful at contaminated sites. These frameworks, designated spatial, temporal, geochemical, hydrological, and other (including risk, ecological, etc.), encourage detailed evaluation of important topic areas using state-of-theart and state-of-the-practice tools. The results of the different frameworks are integrated and used to develop an updated site conceptual model. As shown (Figure 1, bold border) the spatial and temporal frameworks (when, where and how contaminants were released and how the site evolves over time) are relatively important at all sites. At arid and semi-arid sites, such as Riverton, the geochemical and hydrological frameworks (Figure 1, shaded) have proven to be key components that are essential to a reasonable, accurate and effective site conceptual model. Each of these important frameworks is introduced below and evaluated in more detail in the following sections of the report. 


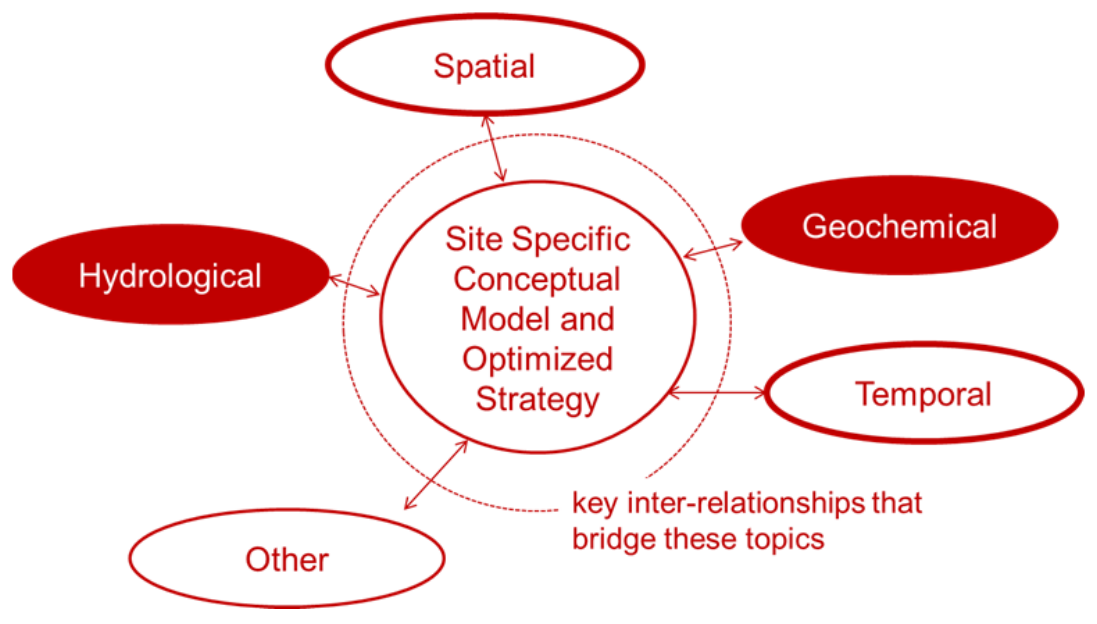

Figure 1. Useful technical frameworks that support optimized environmental and legacy management decisions.

\section{Spatial/Temporal Frameworks}

Key aspects of the temporal framework identified for the Riverton Processing site are associated with periods of active processing of ore, as well as subsequent activities taken to remediate the site including removal of the tailings piles and surface soils. Uranium and vanadium ores were actively processed for approximately six years, from 1958 to 1963; the resulting tailings pile covered about 72 acres of the 140-acre site. Approximately 1.8 million cubic yards of tailings and associated materials were removed from the site in 1988 and 1989 . The area was excavated to an average depth of four feet below the nominal ground surface. An easement and covenant to restrict land use on the former mill site was put in place to prevent exposure to and disturbance of the soil and to limit exposure to any residual contamination.

Figure 2 shows a simplified conceptualization of the spatial and temporal development of a groundwater plume. In the figure, the different zones that develop within a groundwater plume as it evolves through time and space are shown; specifically, the disturbed zone in the near-field, the impact zone in the mid-field, and the transitional zone to background, as well as, general descriptions of the characteristics of each zone. It is important to note, that at some sites, such as Riverton, the transitional zone is truncated or missing because the groundwater plume enters a discharge area or stream.

In the disturbed zone, active physical or chemical removal or destruction methods are warranted; at Riverton, the source tailings and associated materials were physically removed from the site. In the mid-field impact zone, one or a combination of strategies including enhanced attenuation (e.g., geochemical manipulation or reactive barriers), pump \& treat, and/or natural attenuation \& flushing are often suitable. This spatial conceptual framework, based on matching technology attributes to site-specific conditions and needs, has proven to be effective in supporting environmental and legacy management decisions. Key factors in selecting rational and optimal remedy(ies) include implementability, expected performance, uncertainties/risks, and costs for 
actions as they apply to the various target zones. In addition to the traditional factors, emphasis is increasingly placed on sustainability and metrics for evaluating remedial actions and balancing benefits against the associated environmental burdens and collateral damages.

At the Riverton processing site, the important time intervals include: a) the short period of milling and active tailings disposal (1958-1963), b) an interim period with the disposed tailings in place (1964-1987), c) the surface cleanup period (1988-1989), and d) the period following tailings removal (1989-present). These periods correspond, respectively: active high volume release to the groundwater; plume development and evolution; source reduction; and plume/secondary source flushing. In the following detailed technical evaluations, notable hydrological or geochemical impacts of the different site conditions and configurations will be considered.

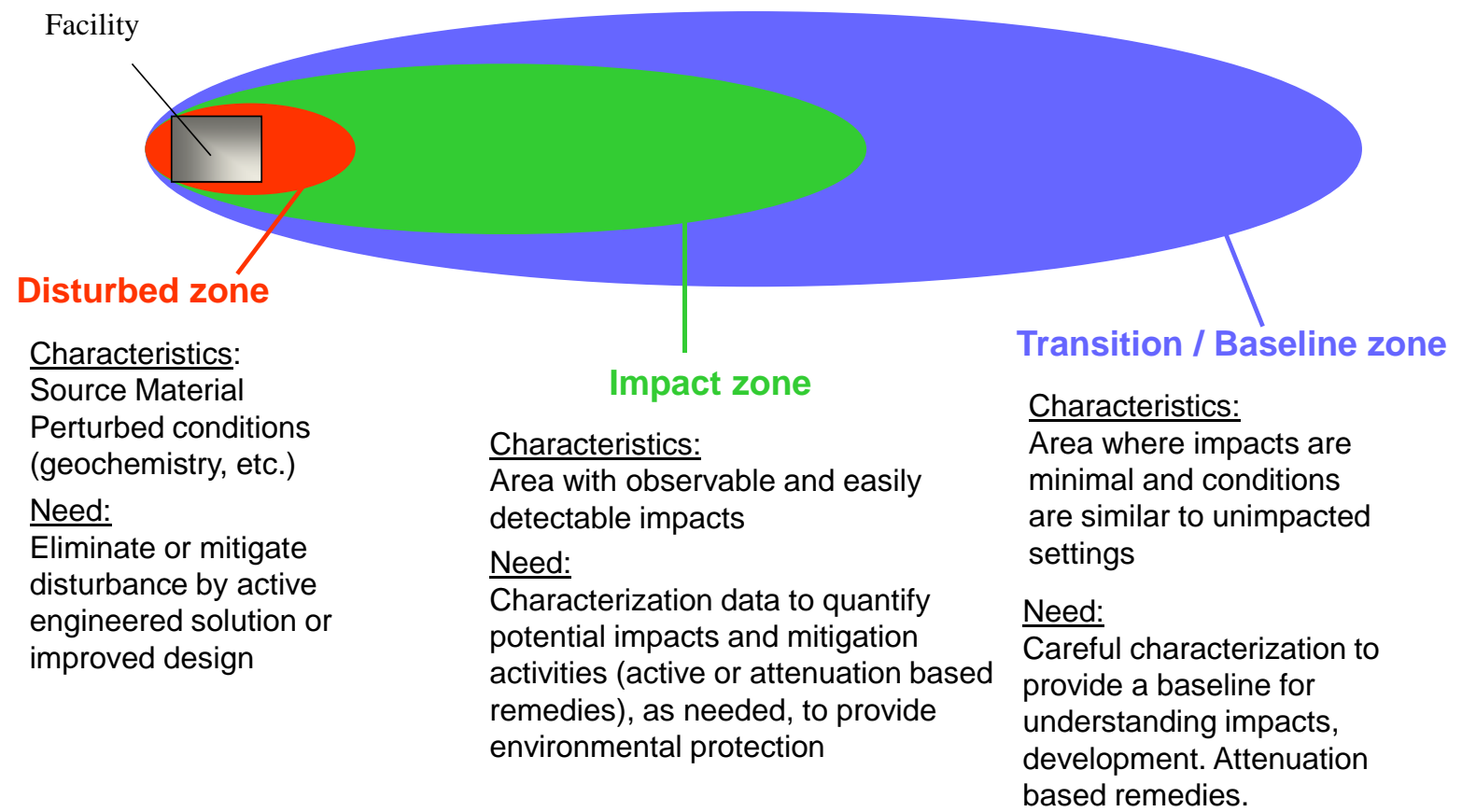

Figure 2. Simplified conceptualization of facility impacts on the surrounding environment and technology matching principles. Colored ovals show generalized zones of the plume. 


\section{Hydrological and Geochemical Conceptual Frameworks - A Preliminary Conceptual Model}

In arid environments, hydrologic boundary conditions are the primary controls on the movement of subsurface contamination. Spatial and temporal changes in these boundary conditions are the primary factors that influence the geometry and structure of a groundwater contaminant plume. Moreover, anthropogenic sources/sinks of water (wastewater discharges, outfalls, water line leaks, unlined evaporation ponds, groundwater injection and extraction wells, etc.) are often significant compared to natural infiltration (see Looney and Falta, 2000). Thus, the importance and influence of anthropogenic sources/sinks is amplified in arid settings.

In all groundwater systems, water flows from sources (areas where water enters the subsurface) toward sinks (areas where water exist the subsurface). At the Riverton Processing site, the water table water is relatively shallow. Lateral flow in the surficial unconfined aquifer is driven by water flowing beneath the site from the Wind River toward the Little Wind River. The surficial aquifer is relatively thin, and the vertical stratification within the plume and plume trajectory are controlled by the relative amounts of water discharging to the Little Wind River or to the vadose zone and atmosphere (evapotranspiration and seeps).

Based on this conceptualization, evapotranspiration and seepage along the path of the plume are parameters that significantly influence the nature and distribution of contaminants in this arid environment. An important related consideration is the fate of the constituents dissolved in the evaporated and transpired water. Fortunately, the behavior of dissolved constituents in this scenario is described in a number of journal articles and reports (Alonzo-Zarza and Wright, 2010; Arakel and D. McConchie, 1982; Carlisle, 1978 and1980; Jutras, et al., 2007; Mann and Horwitz, 1979; Purvis and Wright, 1991; Spotl and Wright, 1992). This supporting literature documents precipitation and accumulation of evaporite minerals such as carbonates and sulfates (e.g., minerals related to calcite and gypsum) in arid and semi-arid settings. Figure 3 summarizes a conceptual model of the dynamic processes that occur in the vicinity of the nearsurface water table in areas of evapotranspiration and outcrop.

At the landscape scale, mineral accumulations form as groundwater flows laterally toward outcrops and shallow groundwater areas where the processes of evaporation, transpiration and seepage concentrate the solution (Alonzo-Zarza and Wright, 2010). In some settings, the minerals accumulate in identifiable horizons, and potentially can solidify into cemented materials (calcretes or gypcretes); in other settings, these minerals can precipitate at the surface along seepage zones. When minerals are formed as a result of lateral groundwater flow and the processes depicted in Figure 3, they are described as "non-pedogenic" in origin (i.e., they are not associated with surficial soil forming and weathering processes that progress downward from the ground surface).

Non-pedogenic evaporite minerals have been identified and characterized in Australia, Europe, Africa, and (notably) in the western United States and Canada. As documented in mineral exploration surveys of broad uncontaminated areas, these accumulation zones contain the major constituents (various sulfates and carbonates) along with accessory minerals containing elements such as uranium (e.g., Peterson et al., 1985; Carlisle, 1978 and 1980). Importantly, the 
conditions at Riverton are similar to the sites where non-pedogenic mineral accumulation has been documented. Thus, dissolved constituents in the water originating at the former processing site would be expected to accumulate as solid evaporites in the vadose zone and near seeps, and these minerals should be similar to natural minerals accumulating in various locations in the Western U.S. Importantly, the mineral accumulation processes should result in relatively understandable geochemical signatures and patterns that can be tested and confirmed using low cost sampling and analysis methods.

Plants have a key role in the conceptual model depicted in Figure 3. In arid to semi-arid climates, phreatophytes extract water and the associated dissolved constituents. For areas located above the plume, the extracted water would contain sulfate, sodium, magnesium, and calcium (elements familiar to desert plants), and trace elements including uranium. Data from plant uptake studies at other LM sites (MACTEC, 1998) indicate that the groundwater concentrations observed at Riverton will not adversely impact plant growth and will not accumulate to harmful concentrations in plants.

The vegetation observed during the site visit (in December 2013) was not actively growing, but appeared to be typical of regional Wyoming arid to semiarid conditions (Figure 4). During the site visit, we identified Sagebrush sp. (e.g., Wyoming Big Sagebrush -- Artemisis tridentate wyomingensis), rabbitbrush sp. (e.g., gray rabbitbrush - Ericameria nauseosa), various bunch grasses (e.g., bluebunch wheatgrass - Agropyron spicatum) and other sagebrush shrub steppe flora. The landscape vegetation also included a few trees such as native cottonwood (Populus sp.) and willow (Salix sp.) and imported Russian Olive (Elaeagnus angustifolia). The flora present in the landscape are predominantly facultative phreatophytes (i.e., capable of extracting shallow groundwater for survival) or obligate phreatophytes (e.g., requiring extraction of shallow groundwater for survival). The quantity and mix of vegetation varied from location to location.

Phreatophyte plants have evolved a number of mechanisms to limit the uptake and accumulation of dissolved constituents extracted from groundwater; for example, Purvis and Wright (1991) document that dissolved constituents are liberated from the water during transport to the surface and that significant mineral accumulation occurs in the vicinity of the deep roots of desert phreatophytes sometimes forming "rhizocrete” deposits associated with root masses (Figure 3). 
a)
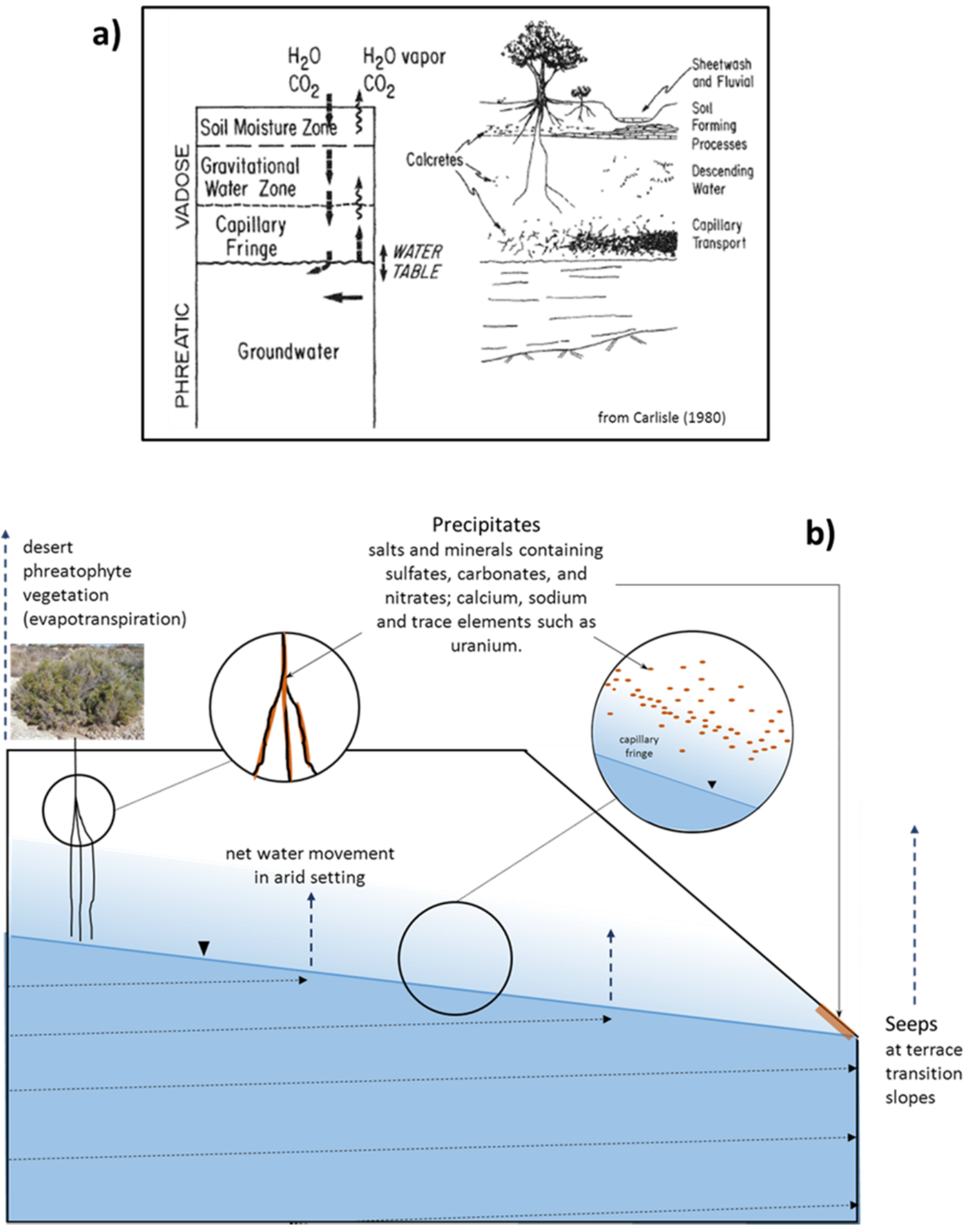

b)

Figure 3. Key geochemical processes associated with non-pedogenic mineral accumulations in arid and semi-arid settings - a) general concept and b) annotated to highlight probable mineral accumulation zones for Riverton 


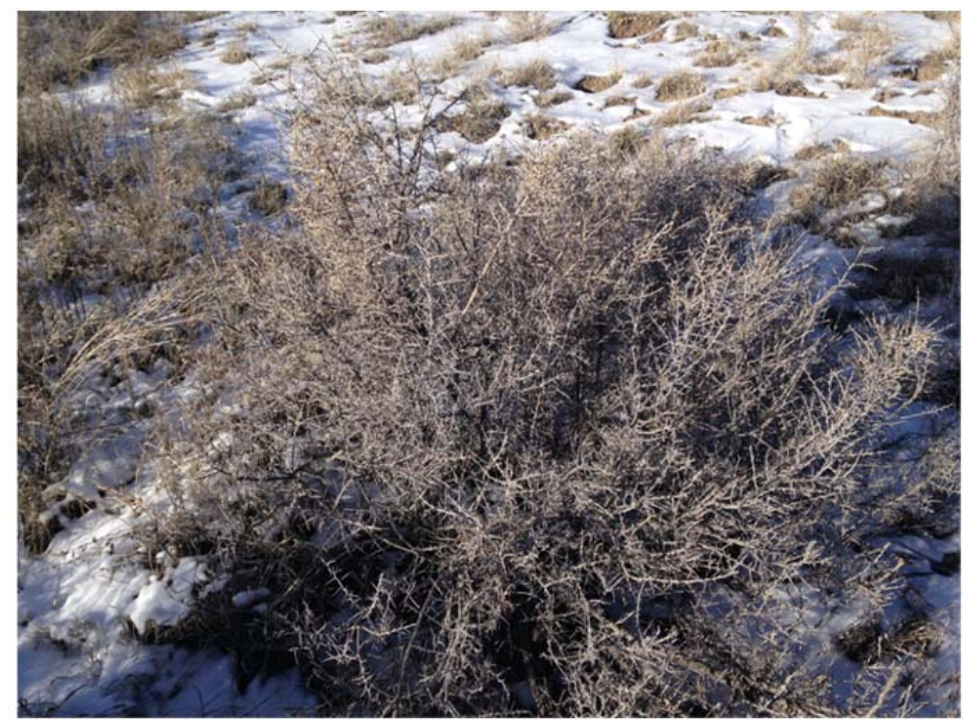

A)

Example Flora from the area surrounding the former Riverton Processing Site

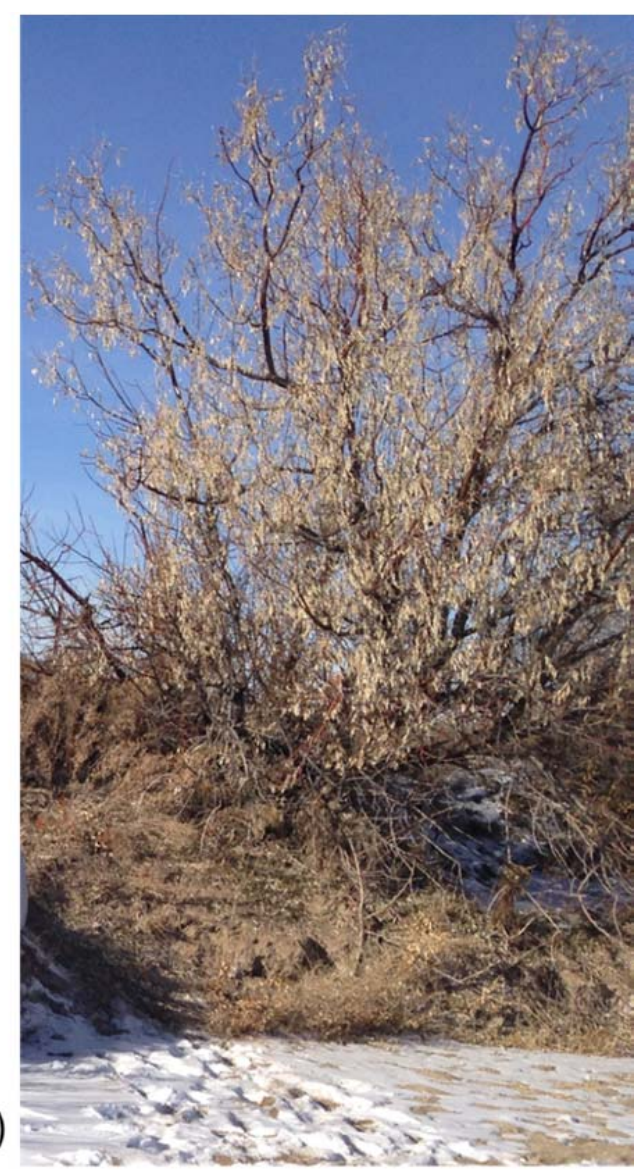

B)

Figure 4. Flora observed (photos from December 2013) in lands overlaying the groundwater plume down gradient of the Riverton Processing Site; a) Example sagebrush shrub steppe flora, b) Russian Olive Tree near Little Wind River outcrop zone.

In addition to plant influences, physical processes would contribute to the formation of residual secondary source contaminants in the vadose zone. During active tailings disposal, the water table elevation would have been relatively high with the potential to leave some residual contamination in the vadose zone near the water table. Groundwater can be moved upward as a result of capillary flow and evaporation. These abiotic physical processes result from the formation of gradients of liquid phase and vapor phase moisture in the shallow vadose zone - moving from the capillary fringe toward the atmosphere. These gradients will result in a net loss of water, and the formation of chemical precipitates, composed of previously dissolved groundwater constituents, as solid salts and minerals. When the water table is close to the ground surface (such as areas near seeps), capillary forces will dominate (Tyler et al. 2006) and draw liquid water to the
Key Points

The climate and vegetation near the Riverton Processing Site are typical of arid areas in which hydrology and geochemistry significantly influence the behavior of subsurface contaminants. In these settings, evaporite mineral phases would be expected to form in the lower vadose zone and in outcrop areas. 
surface where it can evaporate and leave mineral precipitates. In areas where the water table is deeper, capillary forces combined with vapor phase diffusion result in mineral precipitation in the vicinity of the capillary fringe. These solids are subject to episodic weathering (dissolution and re-precipitation). At a site such as Riverton that is subject to episodic flooding, the minerals have the potential to redissolve, resulting in episodic spiking of groundwater contaminant concentrations. Some portion of the contaminants would be expected to go through multiple cycles of precipitation and episodic dissolution during migration down gradient. As part of any characterization, it would be prudent to characterize any plume related minerals (location and nature) to support site assessment and to ensure that these materials do not pose significant risks to humans, livestock or ecology.

\section{Hydrological Conceptual Framework}

The Riverton site is located on an alluvial terrace between the Wind River and the Little Wind River. Groundwater flows in three aquifers beneath the site: (1) a surficial unconfined aquifer, (2) a middle semi-confined aquifer, and (3) a deeper confined aquifer (DOE, 2013). The surficial aquifer consists of approximately 15 to $20 \mathrm{ft}$ ( 5 to $7 \mathrm{~m}$ ) of unconsolidated alluvial material; the semi-confined and confined aquifers are composed of shales and sandstones of the upper units of the Eocene Wind River Formation, which is over $500 \mathrm{ft}(150 \mathrm{~m})$ thick in the vicinity of the site. The depth to groundwater in the surficial aquifer is generally less than $10 \mathrm{ft}(3.5 \mathrm{~m})$ below ground surface (bgs). Groundwater contamination is primarily present in the surficial aquifer with limited contamination of localized areas in the semi-confined aquifer.

The movement of water in the subsurface near the Riverton Processing Site is controlled primarily by the local river systems. The site is located in a valley near the confluence of the Wind River and the Little Wind River (Figure 5). The Wind River to the north has a steeper slope (approximately $0.0026 \mathrm{~m} / \mathrm{m}$ ) compared to the Little Wind River (approximately 0.0015 $\mathrm{m} / \mathrm{m}$ ) to the south. The Wind River also has a higher nominal flow rate (median $9.5 \mathrm{~m}^{3} / \mathrm{sec}, 1^{\text {st }}$ quartile $6.1 \mathrm{~m}^{3} / \mathrm{sec}, 3^{\text {rd }}$ quartile $12.1 \mathrm{~m}^{3} / \mathrm{sec}$ ) when compared to the Little Wind River (median $7.8 \mathrm{~m}^{3} / \mathrm{sec}, 1^{\text {st }}$ quartile $6.1 \mathrm{~m}^{3} / \mathrm{sec}, 3^{\text {rd }}$ quartile $9.3 \mathrm{~m}^{3} / \mathrm{sec}$ ) (USGS, 2014). Figure 6 documents the relative flow of these two rivers for a three week period during March and April 2014. Due to the steeper gradient and higher flow, the Wind River has a lower sinuosity (sinuosity = channel length / equivalent valley length $\cong 1.2$ ) compared to the Little Wind River (sinuosity 1.5). 


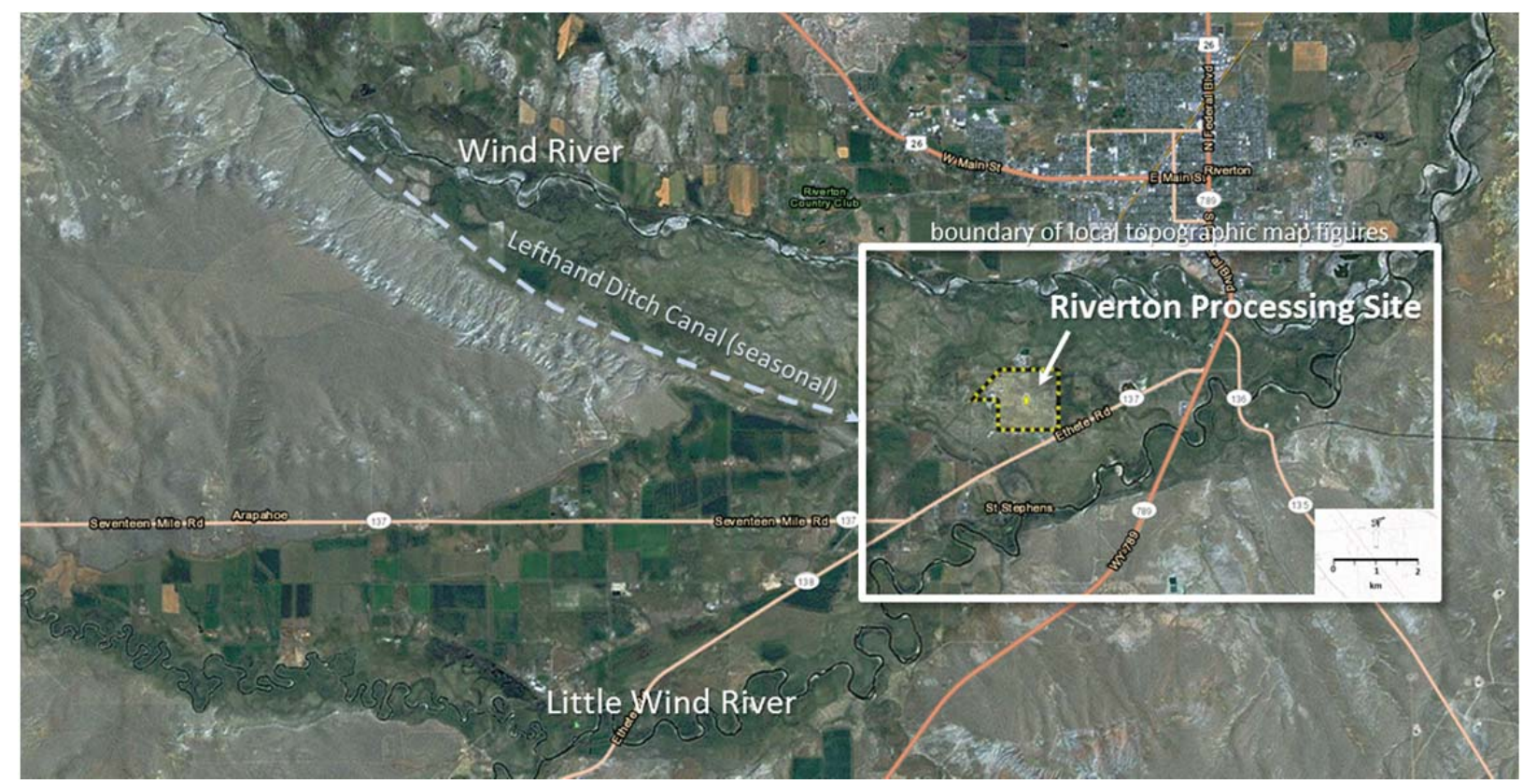

Figure 5. General hydrologic setting of the Riverton Processing Site, Riverton WY.

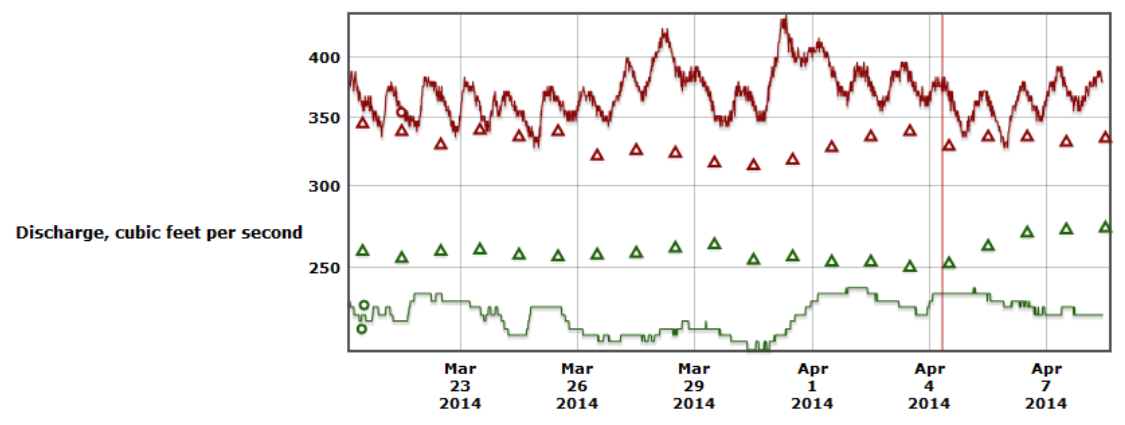

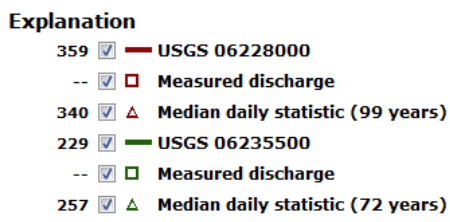

Figure 6. Flow in the Wind River (06228000) and Little Wind River (06235500) at the USGS gauging stations near Riverton WY, Mar 20 - Apr 8, 2014 (USGS, 2014)

The primary driving force for the movement of groundwater in the surficial aquifer is lateral flow beneath the valley as water moves from the Wind River toward the Little Wind River. The natural flow direction is shown in Figure 7 and is not directly south from the Wind River to the Little Wind River as might be expected. The two rivers are at the same elevation at the confluence, while the steeper gradient in the Wind River results in a difference in elevation in the two rivers east of the confluence. The net result of this relationship is shown in Figure 7. The isopotential lines (dashed) on this map connect locations of approximately equal elevation on the two rivers. These lines were used to project natural flow directions (solid lines with arrows) toward the ESE. 


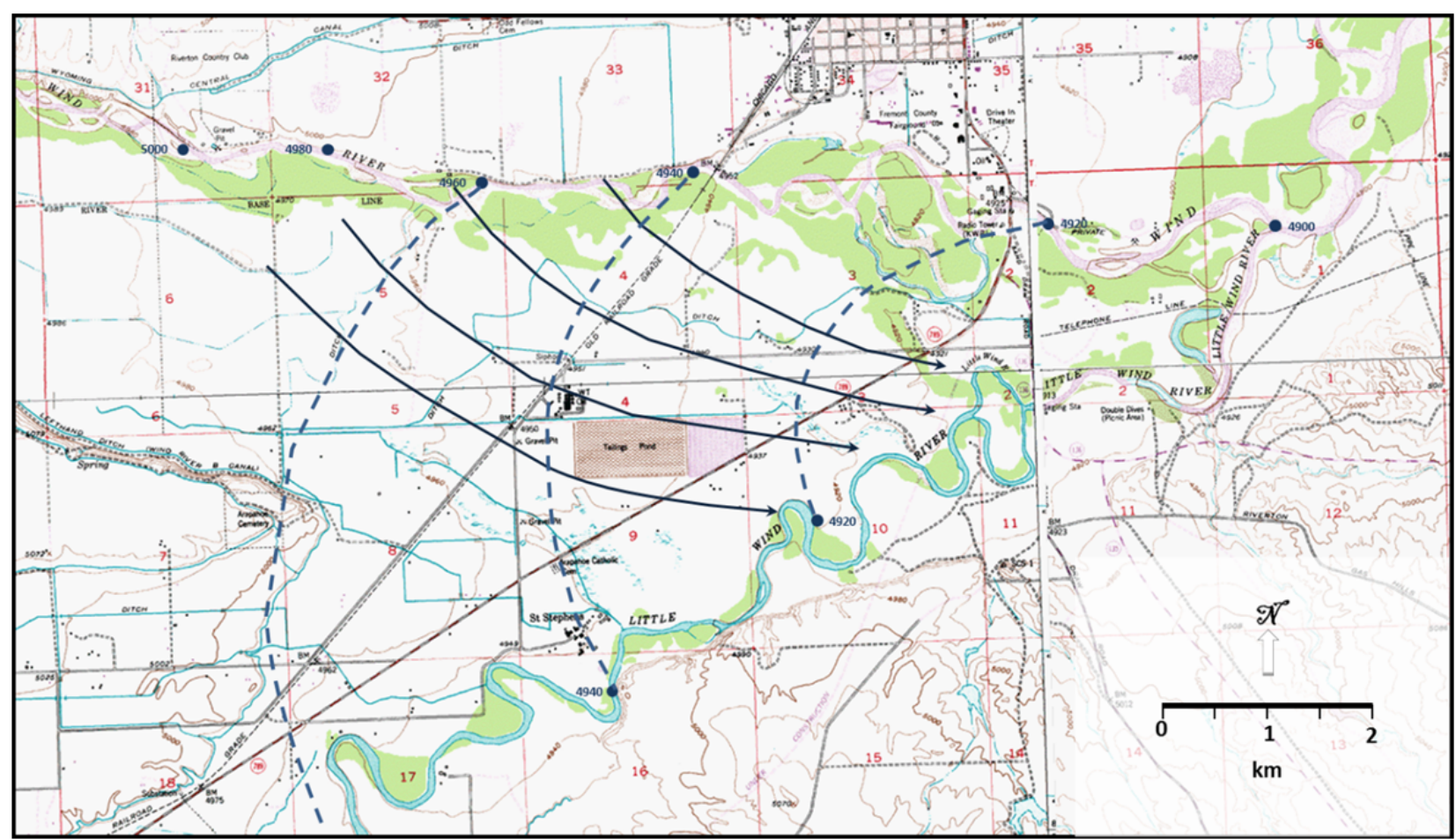

Figure 7. Natural flow gradients between the Wind River and Little Wind River near the Riverton Processing Site, Riverton WY (based on USGS topographic maps); the former tailings areas depicted as a brown rectangle in the left center of the map

Three notable activities/conditions modify the influence the natural gradients and flow direction in the surficial aquifer in the vicinity of the Riverton Processing Site; these are: a) irrigation b) historical uranium milling and tailings disposal operations, and c) episodic flooding. Surface water discharges and other actions associated with the ongoing sulfuric acid production operation also have the potential to influence the natural gradients and flow directions in the surficial aquifer.

The Riverton community actively uses water from both the Wind River and Little Wind River to support agricultural and recreational activities. One of the largest water uses is irrigation; irrigated lands are a dominant feature of the satellite imagery shown in Figure 5. Significant infrastructure is in place to support irrigation; the Lefthand Ditch Canal (Figures 5 and 8) operates seasonally to move large volumes of water from an upstream (higher elevation) on the Wind River to areas throughout the valley. This irrigation water is distributed through an array of unlined ditches and results in general increases of infiltration in the shaded areas on Figure 8. Irrigation would increase the amount of water flowing through the subsurface, increase water levels in the surficial aquifer, and shift the flow directions (as shown by the arrows). The impacts to the groundwater induced by irrigation would overlay on the natural flow system, and would be expected to produce cyclic temporal (seasonal) variability in flow directions and rates. 


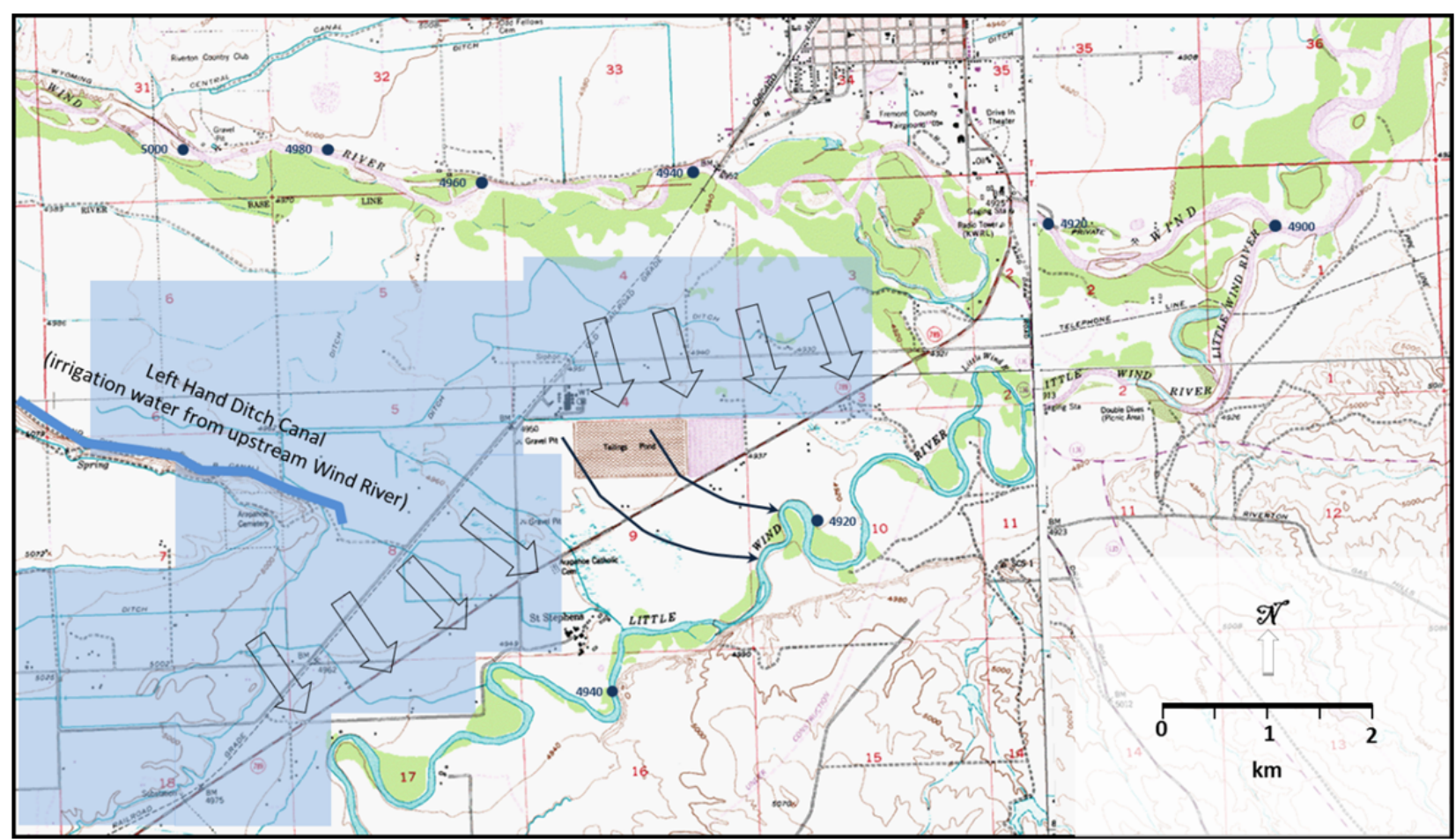

Figure 8. Areas where irrigation ditches are present (shaded) and qualitative influence of irrigation on groundwater flow direction in the surficial aquifer (arrows)

The uranium and vanadium milling and processing, and the associated tailings disposal, occurred during and approximately 6 year period (between 1958 and 1963). During this period, the tailings were disposed as a slurry (using large volumes of water), so that water levels in the source area and down gradient would be increased. Further, the slurry water draining from the tailings contained elevated levels of various process-related ions and tailings-related contaminants. These contaminants would be added to the top of the surficial aquifer, impacting the water table and the upper portion of the aquifer in the near-field area (Figure 9). After the removal of the tailings, the water table would move down, and leave contaminants in the lower portion of the vadose zone along formerly contaminated flow lines. This process would complement source material brought into the vadose zone by evapotranspiration, resulting in an increase in the amount of residual contamination and secondary source material in the vadose zone available for future mobilization. Below the water table, the plume would be expected to vary laterally away from the source, to be stratified vertically, and to move through the surficial aquifer based on hydrologic driving forces that will vary over time. During dry periods, the flow lines will discharge to both the Little Wind River and to the vadose zone and atmosphere (via evapotranspiration). Floods, irrigation and wet periods will result in infiltration and force flow lines through the middle and deeper portion of the surficial aquifer. 


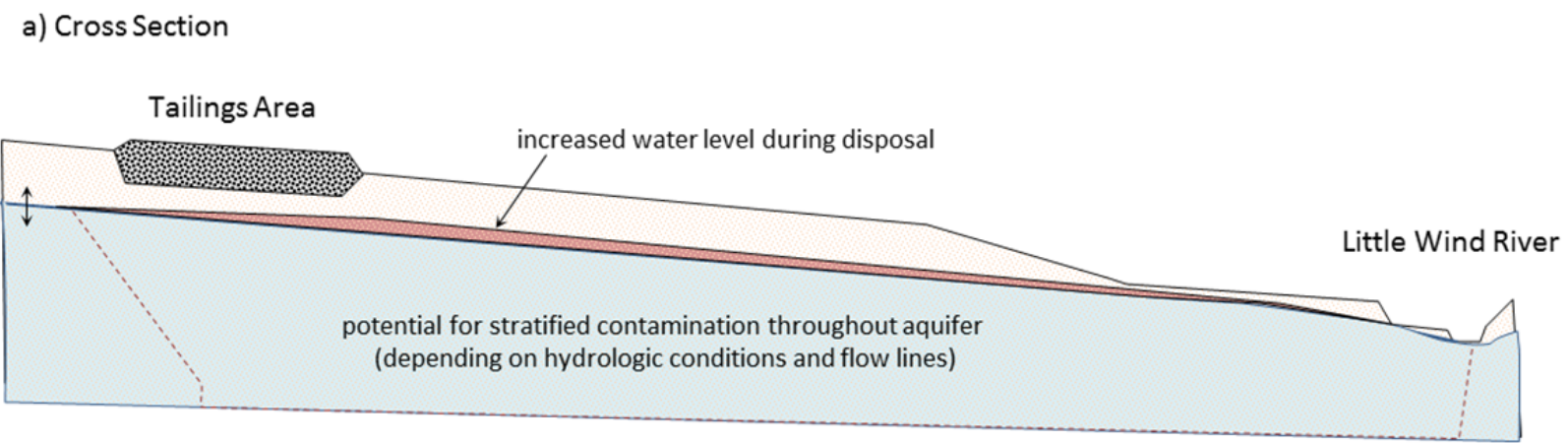

b) Plan View

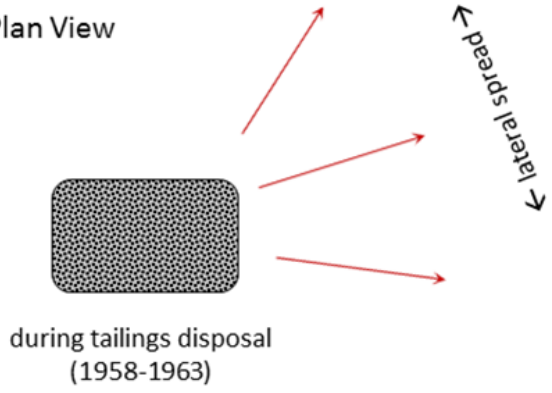

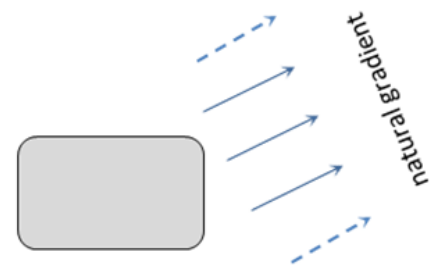

after tailings disposal

Figure 9. Hydrologic impacts of tailings disposal (1958-1963)

Because the Riverton Processing Site is located on an alluvial terrace between the Wind River and the Little Wind River, the area has been impacted by episodic flooding. The impact of river flooding events on the site includes the following: accelerated formation of an oxbow lake on the Little Wind River in 1995; episodic spikes in groundwater contaminant concentrations; transient increases in infiltration in flooded areas, and high groundwater levels (DOE, 2013). During the period during and after milling operations, significant floods of the Little Wind River occurred in 1963, 1965, 1967, 1983, 1991, 1995, and 2010. Peak discharge in 2010 was greater than $227 \mathrm{~m}^{3} / \mathrm{sec}\left(8,000 \mathrm{ft}^{3} / \mathrm{sec}\right)$; this peak flow was greater than 30 times the median flow rate $\left(7.8 \mathrm{~m}^{3} / \mathrm{sec}\right)$ for the Little Wind River. Significant floods of the Wind River that likely affected the site occurred in 1963, 1967, 1971, 1991, 1997, 1999, and 2011. In 2011, peak stream discharge was greater than $227 \mathrm{~m}^{3} / \mathrm{sec}$
Key Points

- The primary hydrological force moving water laterally beneath the site is the flow of water from the Wind River toward the Little Wind River

- Seasonal irrigation and episodic flooding are modifying factors that overlie on the basic flow pattern and result in transient changes in flow direction and rate

- During the short period of tailings disposal, the water table elevation would have been higher in the near-field and mid-field areas

- The Little Wind River comprises actively evolving meanders. The area near the river has been reworked and contains a significant number of past cutoff meanders and oxbow lakes. 
$\left(8,000 \mathrm{ft}^{3} / \mathrm{sec}\right)$; this peak flow was greater than 24 times the median flow $\left(9.5 \mathrm{~m}^{3} / \mathrm{sec}\right)$ for the Wind River. The flooding events would initiate a number of possible mechanisms that would result in transient spikes in groundwater concentration. These mechanisms include flushing and migration of contaminants from the vadose zone, increases in water levels resulting in inundation and leaching of contaminants from the vadose zone, changes in the sampling of the plume by a monitoring well (i.e., changes in water flow direction or rate or in plume stratification relative to the well screen).

Based on the morphometric parameters listed above, the Wind River would be classified (Rosgen, 1994) as a Type C river and the Little Wind River would be Type E river. A dominant feature of the type E Little Wind River is the high sinuosity as exhibited by significant meanders and formation of oxbow lakes (Figure 10). The processes that form the meanders and oxbow lakes are ongoing and there is a clear signature on the satellite image of a large number of past oxbow lakes in the landscape north of Little Wind River. The long term reworking of this area would result in erosion and local connection of the surficial and semiconfined aquifers. These connections would also provide pathways for both of these aquifers to drain to the Little Wind River. The areas of former oxbow lakes are important as they would contain significantly higher levels of organic matter, reduced mineral content, and would contain reduced zones that would interact with plume constituents as they pass through the area. 

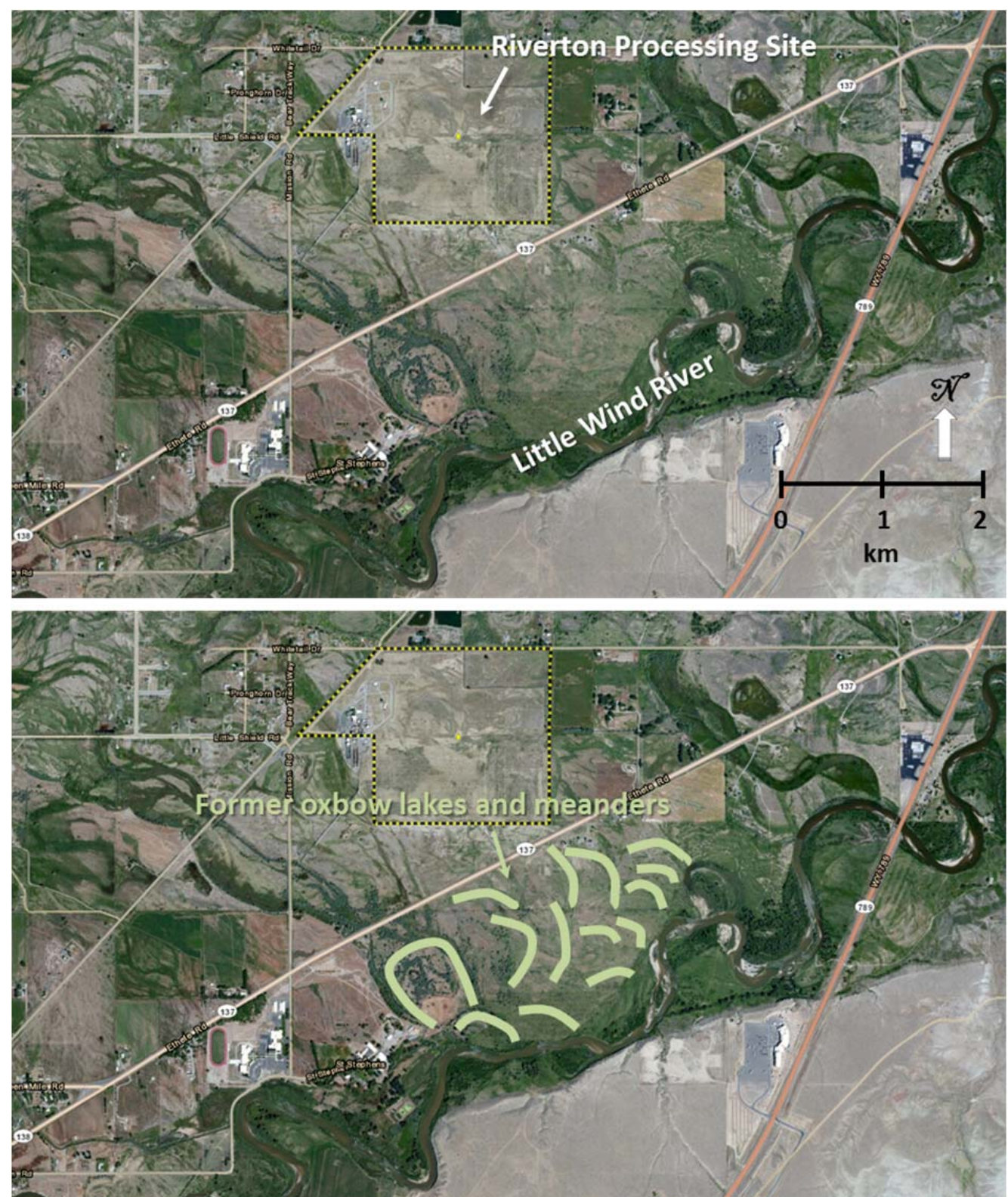

Figure 10. Satellite image of the Little Wind River near the Riverton Processing Site; some examples of signatures of past oxbow lakes are annotated on the lower panel 


\section{Hydrological Framework Continued -- Scoping Evaluation of Evapotranspiration}

At the Riverton Processing Site, several wells in the surficial aquifer have been instrumented with data loggers to monitor water table elevation, specifically, to evaluate the spatial relationships between water levels in different wells, the dominant flow directions, and temporal variability in these relationships and vectors. The instrumented wells are designated in Figure 11. Traditionally the data from all of the instrumented wells are plotted together as hydrograph, piezometric surface elevations versus time, as shown in Figure 12 to support the primary sitewide monitoring objectives. Closer inspection of the data in Figure 12, suggests that a high frequency diurnal (daily) signal may be present in the record for all of the wells.

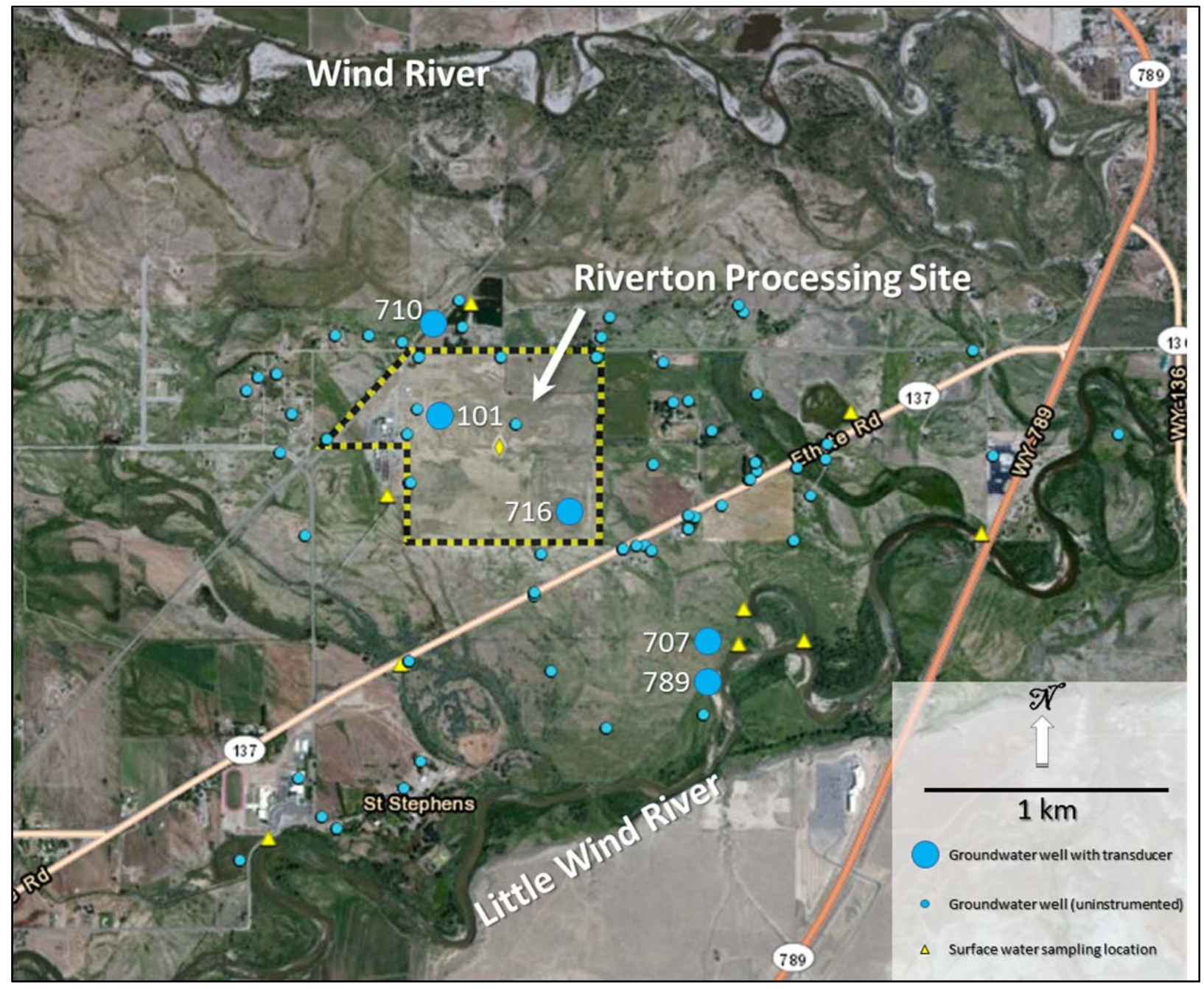

Figure 11. Groundwater wells in the vicinity of the Riverton Processing Site instrumented with water level transducers and data loggers. 


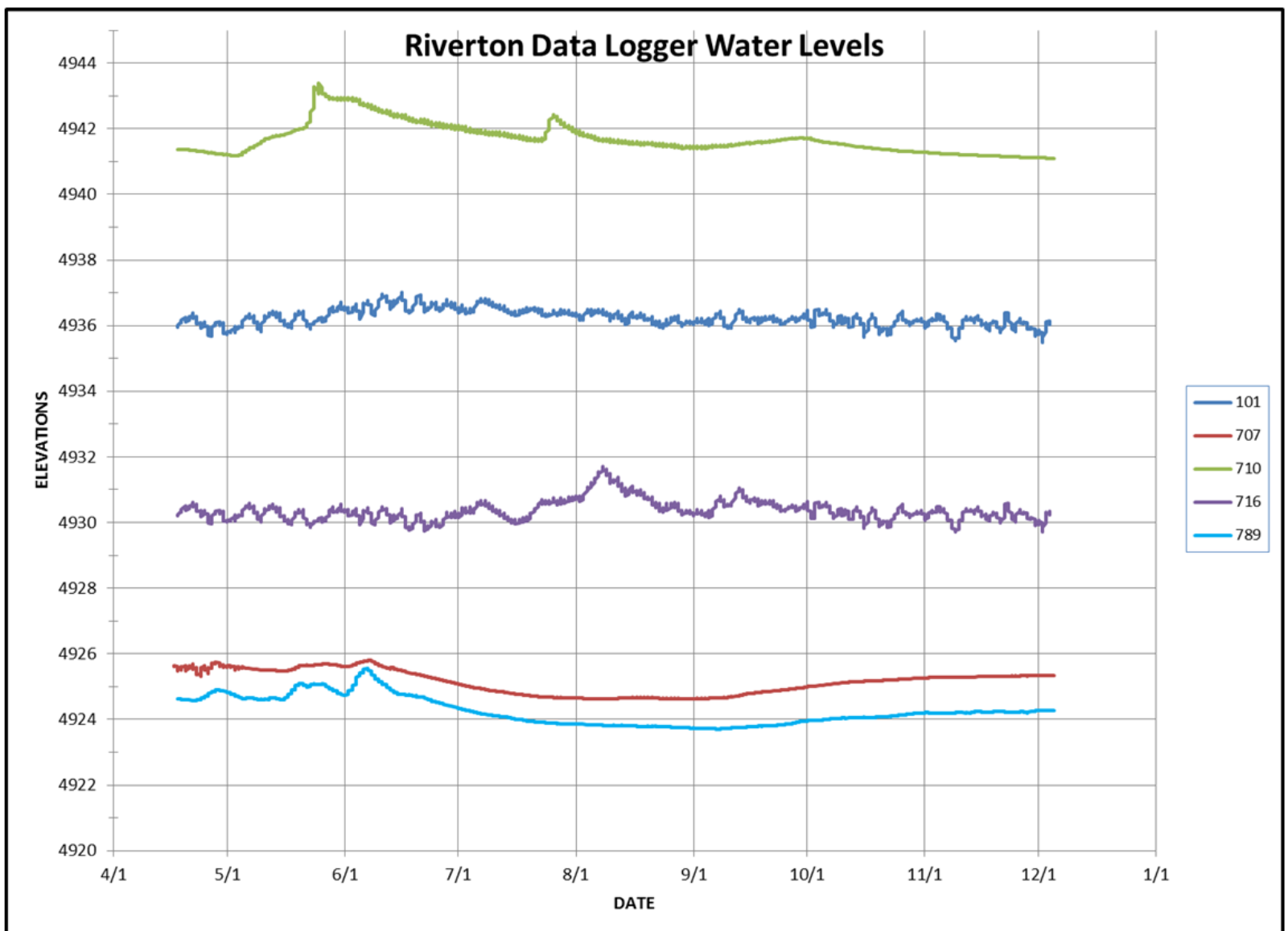

Figure 12. Traditional hydrograph showing water levels in selected wells over a 10 month period (from DOE, 2013)

In areas where plants directly tap groundwater for their water supply, hydrographs from wells screened near the water table typically display diurnal fluctuations during the growing season. These diurnal trends are superimposed on the overarching temporal trends associated with precipitation events, changes in river stage, floods, other seasonal variations, pumping, and longer-term climate patterns. If a significant level of evapotranspiration (ET) related to groundwater use by phreatophyte plants is occurring, the hydrograph data will contain both the low frequency information associated with the overarching trends, and the high frequency diurnal signal related to the extraction of water by plants. This diurnal pattern is not emphasized in the traditional plotting of hydrographs because of the span needed on the Y-axis to accommodate all of the wells and because of the long timeframe on the $\mathrm{X}$-axis needed to document seasonal and long-term trends on a plume-wide scale. In arid and semi-arid climates with a shallow water table, ET-related diurnal variation can be better observed when an individual well is plotted using a narrower elevation span and a shorter timeframe. Figure 13 is an example of such a graph for well 716, an instrumented well near the SE corner of the Riverton Processing Site boundary. This figure indicates a diurnal variation in water table elevation of approximately 0.12 feet in this well during a period spanning late spring through early fall. Note that the span on the Y-scale (piezometric surface elevation) in Figure 13 is 1.8 feet compared to 24 feet in Figure 12). 


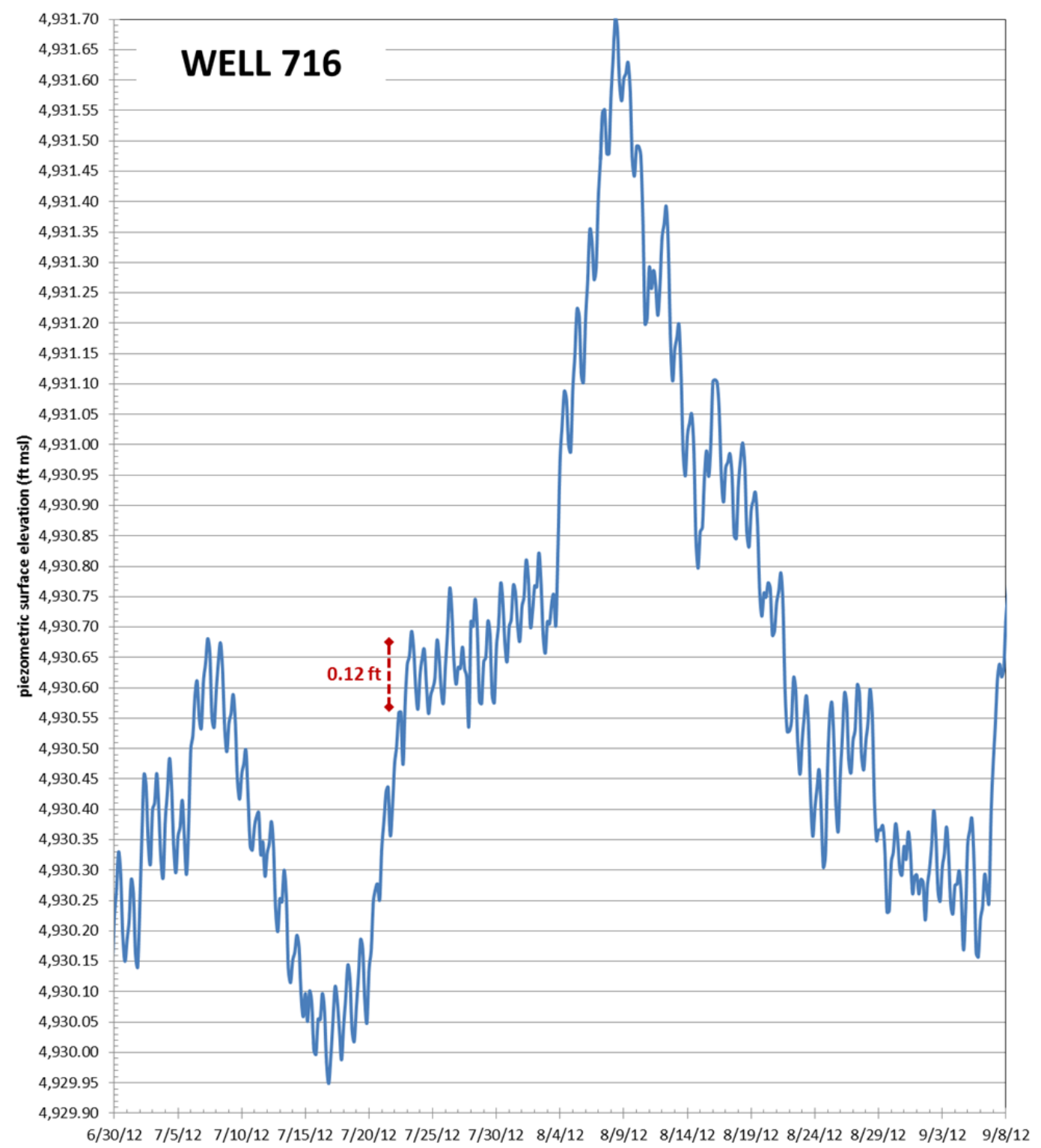

Figure 13. Hydrograph showing the diurnal variation in well 716 during the period of 06/30/2012 through 09/08/2012

The magnitude of the diurnal water table fluctuations shown in Figure 13 are typical of those observed in areas with phreatophyte vegetation (e.g., White, 1932; Troxell, 1936; Tromble, 1977; Farrington et al., 1990; Laczniak et al., 1999; Dulohery et al., 2000; Scott et al., 2002; Dahm et al. (2002); Loheide et al., 2005) and similar diurnal fluctuations have been observed in data from vadose zone tensiometers (Remson and Randolph, 1958) and stream gauges (Bond et al., 2002). Previous studies at arid sites indicate that ET is the primary contributor to diurnal oscillations in water table elevation (e.g., Figure 13) and local stream flow (e.g., Figure 6) and that the fluctuations are not the result of barometric pressure, temperature, or pumping at most sites (Loheide et al., 2005, Bond et al., 2002). 
The literature indicates that the diurnal pattern is generally related to dynamics of daily plant water use. During their growing season, phreatophyte plants transpire (pump) shallow groundwater during daylight hours, overcoming inflow, so the water table declines during that period. Similarly, at night, when transpiration significantly decreases, the water table will rebound because of inflow. Twice per day, the plant water use is balanced by inflow, producing a peak and trough in the water level record in the morning and evening, respectively.

White (1932) recognized that the diurnal water table fluctuations in some settings were a product of the balance of plant water use and inflow. He proposed a straightforward method to estimate evapotranspiration from an analysis of well hydrographs using the following expression:

$$
\begin{aligned}
\mathrm{ET}_{\mathrm{g}} & \cong(\text { specific yield }) \text { (net inflow or outflow }+ \text { daily change in storage) } \\
& \cong \mathrm{S}_{\mathrm{y}}[24(\mathrm{r})+(\Delta \mathrm{s} / \mathrm{t})]
\end{aligned}
$$

where:

$\mathrm{ET}_{\mathrm{g}}$ is the rate of evapotranspirative consumption of groundwater averaged over a 24-hour period (length/day)

$\mathrm{S}_{\mathrm{y}}$ is the specific yield (dimensionless)

$r$ is the inflow (night time recovery rate, length / hr) which is multiplied to account for a 24 hour period

$\Delta s / t$ is the daily change in storage (length/day)

Consistent with Loheide et al. (2005), we have included the subscript "g" in $\mathrm{ET}_{\mathrm{g}}$ to emphasize that this approach is calculating the component of ET that is derived from the saturated zone (i.e., groundwater). In semi-arid and arid settings with shallow water tables and predominant coverage by phreatophyte plants, groundwater is the principal source of water for vegetation so $\mathrm{ET}$ and $\mathrm{ET}_{\mathrm{g}}$ are roughly equivalent. In other environments, however, stored moisture in the vadose zone can be a significant water source for vegetation, in which case $\mathrm{ET}_{\mathrm{g}}$ will be a partial or negligible component of ET.

Figure 14 demonstrates the application of the White (1932) Method to data from Well 707 at the Riverton Disposal Site. Figure 14 also demonstrates equivalent results for a Modified White Method that uses a simplified graphical approximation. The modified method uses the measured oscillation in daily water table elevation and calculates $\mathrm{ET}_{\mathrm{g}}$ using the equation:

$\mathrm{ET}_{\mathrm{g}} \cong \mathrm{S}_{\mathrm{y}}\left[2\left(\Delta \mathrm{h}_{\mathrm{wt}}\right)\right]$

where:

$\Delta \mathrm{h}_{\mathrm{wt}}$ is the daily oscillation in water table -- the maximum value projected down to a baseline that reflects the longer term trends (length/day)

all other parameters are as defined above

Assuming a specific yield of approximately 0.2, the results of both methods indicate that $\mathrm{ET}_{\mathrm{g}}$ is approximately $0.0041 \mathrm{ft} /$ day $(1.26 \mathrm{~mm} /$ day $)$ for the period shown, in early September, in the vicinity of Well 707. 


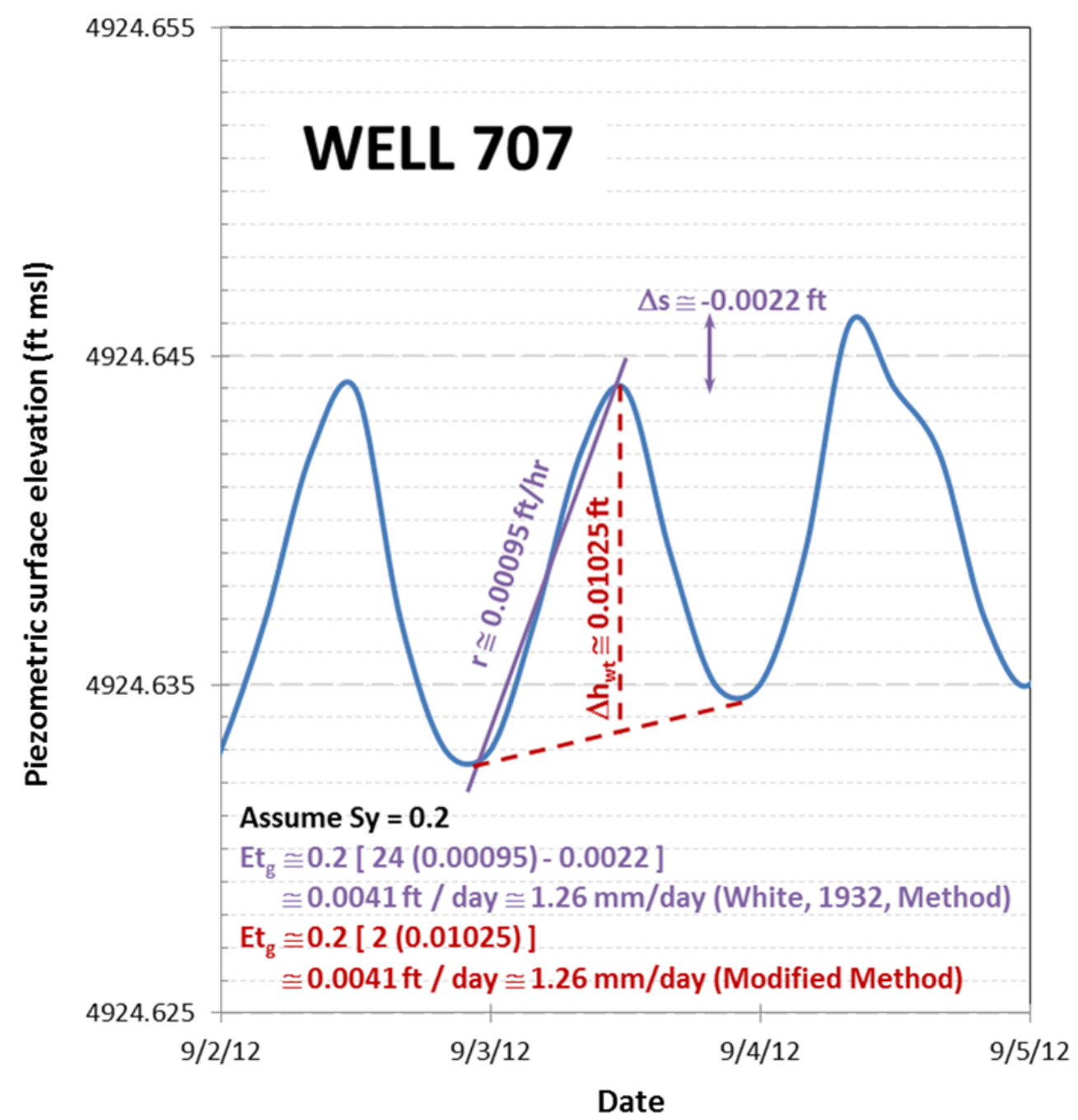

Figure 14. Estimation of ET from hydrograph from well 707 (09/03/2012 through 09/04/2012) using the White (1932) Method and a Modified Method

The four major assumptions of the White method are: 1) diurnal water table fluctuations result from plant water use; 2) groundwater consumption by plants is negligible at night; 3) a constant rate of flow into the near-well region occurs over the entire day, and 4) a representative value of specific yield can be determined. The White method has been compared with other estimates of ET $_{\mathrm{g}}$ by Gatewood et al. (1950), Tromble (1977), Farrington et al. (1990), and Loheide (2005). These studies found reasonable agreement between the various methods and generally support the use of the simple hydrograph based methods unless conditions are present that substantively violate the assumptions listed above. 
As shown in the three panels of Figure 15, evapotranspiration varies throughout the year in response to seasonal climate and plant growth factors. The diurnal variation, or oscillation, in piezometric elevation in Well 707 level is approximately 0.003 feet in the early spring, 0.01 feet in the summer, and 0.001 feet in the winter. Similar diurnal patterns are observed in all of the Riverton Processing Site wells that are equipped with data loggers, although the magnitude of the diurnal oscillations varies significantly from location to location (see Figure 16).

\section{Key Points}

Hydrographs collected from monitoring wells near the Riverton Processing Site exhibit diurnal variations typical of arid sites with shallow water tables. The water table oscillations are primarily the result of ET by phreatophyte plants. The approximate amount of water extracted from the subsurface through this important hydrologic boundary can be estimated from the hydrographs. The ET extracted water varies throughout the year and is the highest during the active growing season (late spring through early fall.
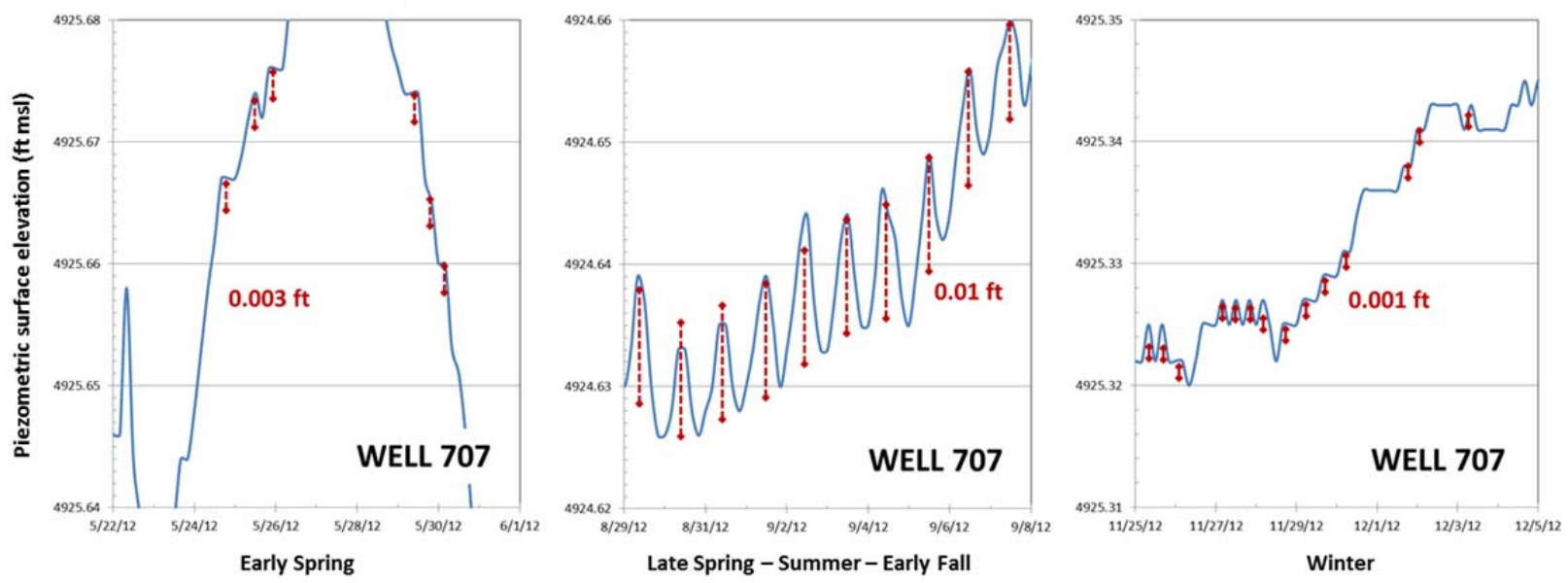

Figure 15. Seasonal hydrographs from well 707 annotated with the approximate diurnal piezometric surface variation for the periods depicted - note that the span on the y-scales is the same $(0.04 \mathrm{ft})$ in these three graphs so that they can be directly compared 


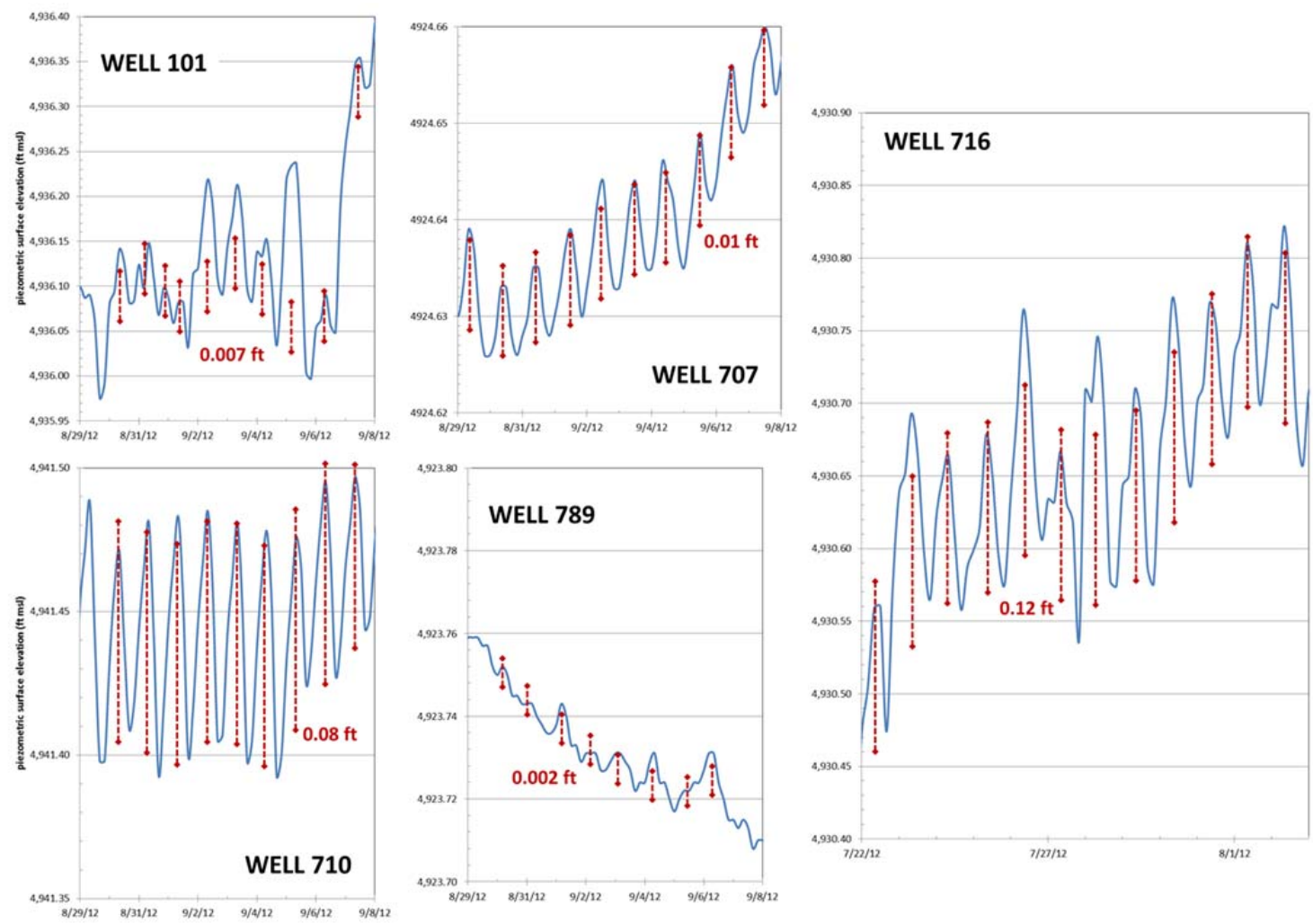

Figure 16. Summer hydrographs from instrumented wells in the surficial aquifer near the Riverton Processing Site annotated with the approximate diurnal piezometric surface variation note that the span on the $y$-scales varies from graph to graph so that they cannot be directly compared

The scoping results for all of the instrumented wells are summarized in Table 1. Annualized, the estimated $\mathrm{ET}_{\mathrm{g}}$ values varied from 61 to $2365 \mathrm{~mm} / \mathrm{yr}$, with a median value of $204 \mathrm{~mm} / \mathrm{yr}$. The lowest estimated values are at the wells closest to the Little Wind River. A number of factors may contribute to the spatial differences, including vegetation types and densities, differences in lithology, differences in water table elevation/depth, local transient irrigation or pumping, and potential errors related to areas of the site not fitting the assumptions and requirements of the White (1932) method. Further, the specific yield assumed (0.2) is a nominal generic value and the estimates would be improved by incorporating site specific information. These scoping level calculations provide an order of magnitude $\mathrm{ET}_{\mathrm{g}}$ range (approximately 100 to 1000 $\mathrm{mm} / \mathrm{yr}$ ) to support incorporating this important hydrologic boundary into conceptual and quantitative models.
Key Points

The data demonstrate that uptake of groundwater water by phreatophyte plants and subsequent evapotranspiration is occurring in the vicinity of the Riverton Processing Site. An annualized order-ofmagnitude estimate for this process ranges from 100 to $1000 \mathrm{~mm} / \mathrm{yr}$. The estimated $\mathrm{ET}_{\mathrm{g}}$ varied significantly from location to location. Additional evaluation would be useful to determine the reasons for the spatial variability and to confirm and refine the estimates. 
Table 1. Summary of ET $\mathrm{g}_{\mathrm{g}}$ scoping estimates based on hydrographs of instrumented wells near the Riverton Processing Site

\begin{tabular}{|c|c|c|c|c|c|c|c|c|c|c|c|}
\hline \multirow[b]{3}{*}{ Well } & \multicolumn{3}{|c|}{ late spring } & \multicolumn{3}{|c|}{ summer } & \multicolumn{3}{|c|}{ late fall/winter/early spring } & \multirow{2}{*}{\multicolumn{2}{|c|}{$\frac{\text { ANNUAL** }}{\mathrm{Et}_{\mathrm{g}}}$}} \\
\hline & \multirow{2}{*}{$\begin{array}{c}\Delta \mathrm{h} \\
\mathrm{ft} \\
\end{array}$} & \multicolumn{2}{|c|}{$\mathrm{Et}_{\mathrm{g}}{ }^{*}$} & \multirow{2}{*}{$\begin{array}{c}\Delta \mathrm{h} \\
\mathrm{ft} \\
\end{array}$} & \multicolumn{2}{|c|}{$\mathrm{Et}_{\mathrm{g}}$} & \multirow{2}{*}{$\begin{array}{c}\Delta \mathrm{h} \\
\mathrm{ft} \\
\end{array}$} & \multicolumn{2}{|c|}{$\mathrm{Et}_{\mathrm{g}}$} & & \\
\hline & & $\mathrm{ft} /$ day & $\mathrm{mm} / \mathrm{day}$ & & $\mathrm{ft} / \mathrm{day}$ & $\mathrm{mm} /$ day & & $\mathrm{ft} / \mathrm{day}$ & $\mathrm{mm} / \mathrm{day}$ & $\mathrm{ft} /$ year & $\mathrm{mm} /$ year \\
\hline 101 & 0.005 & 0.0020 & 0.61 & 0.007 & 0.0028 & 0.853 & 0.001 & 0.0004 & 0.122 & 0.542 & 165 \\
\hline 707 & 0.003 & 0.0012 & 0.37 & 0.010 & 0.0040 & 1.219 & 0.001 & 0.0004 & 0.122 & 0.668 & 204 \\
\hline 710 & 0.020 & 0.0080 & 2.44 & 0.080 & 0.0320 & 9.754 & 0.001 & 0.0004 & 0.122 & 4.754 & 1449 \\
\hline 716 & 0.030 & 0.0120 & 3.66 & 0.120 & 0.0480 & 14.630 & 0.010 & 0.0040 & 1.219 & 7.760 & 2365 \\
\hline \multirow[t]{2}{*}{789} & 0.001 & 0.0004 & 0.12 & 0.002 & 0.0008 & 0.244 & 0.001 & 0.0004 & 0.122 & 0.200 & 61 \\
\hline & & & & & & & & & Median & 0.668 & 204 \\
\hline \multicolumn{12}{|c|}{${ }^{*}$ Assumes $\mathrm{S}_{\mathrm{y}}=0.2$ and simplified graphical approach for scoping approximate $\mathrm{ET}_{\mathrm{g}}$} \\
\hline \multicolumn{12}{|c|}{ ** Assumes late spring $=45$ days, summer $=135$ days, and late fall/winter/early spring $=185$ days } \\
\hline & & & & & & & & & & & \\
\hline
\end{tabular}

\section{Geochemical Framework for Uranium Millings and Tailings Disposal}

The geochemical framework at the Riverton site is dominated by seepage from the tailings pile over a thirty year period, and subsequent processes that affected the chemical composition of pore fluids in the vadose zone and aquifers. The potential processes that affected bulk groundwater chemistry from operation of the mill to present are:

- Mineralization from the reaction of the tailings fluid with vadose zone and aquifer minerals

- Mineralization from degassing of $\mathrm{CO}_{2}$ at the capillary fringe

- Mineralization from evaporation at the capillary fringe

- Diffusion of constituents into low permeability materials

- Ion exchange and precipitation along the flow path

- Reaction with natural organic matter

The first three processes are localized in discrete zones within the system, and the latter three processes can occur anywhere along the flow path of contaminated groundwater. All six processes impact the chemical composition of pore fluids in different ways such that processes can be identified from consideration of the bulk chemistry of groundwater. Each of these processes will be discussed in detail in the following sections.

An additional process that impacts the geochemistry of the groundwater at the Riverton site is effluent stream seepage into groundwater from the upgradient sulfuric acid plant resulting in the addition of sulfate to groundwater in the western portion of the site. The plant was associated with the mill at Riverton and is still operated by a private company.

\section{Near-Field Mineralization}

During operation of the plant, the Riverton mill used both a sulfuric acid and carbonate process (DOE, 1998 SOWP). However, the composition of the leachate was dominated by acidity and high sulfate concentrations during mill operations. Samples collected within and beneath the tailings pile obtained approximately two decades after cessation of mill operations indicate that 
post-operation leachate was acidic and sulfate-rich (Narasimhan et al., 1982; Markos and Bush, 1982). In the depth profiles through the tailings pile, presented by Narasimhan et al. (1982), the $\mathrm{pH}$ values ranged from 1.7 to 6.3 (at interface with soil). When these fluids came into contact with the calcareous rocks beneath the pile, the $\mathrm{pH}$ in the leachate was neutralized resulting in the likely precipitation of gypsum, uranium minerals and other phases. Though this zone of mineralization has not been specifically documented during previous characterization activities, its presence is suggested by the profiles, through the tailings pile and into the soil, of acid soluble constituents presented by Markos and Bush (1982). The highest values for cadmium and nickel in the profiles were located within the top meter of soil beneath the pile. Mineralization beneath the tailings pile attenuated but did not prevent movement of uranium into groundwater. The minerals remained a secondary source of uranium and other contaminants.

The excavation of soils beneath the former tailings pile to 4 feet below ground surface likely removed much of the near-field mineralization. This is supported by the relatively low uranium concentrations found in GeoProbe soil samples taken from within the footprint of the former tailings pile (DOE, 2013) as compared to samples obtained from soils collected farther down gradient in the vadose zone above the groundwater plume.

Key Points

- The soil zone beneath the former tailings disposal area attenuated some of the contamination, but did not prevent the movement of uranium into groundwater. - Excavation of contaminated soil during the off-site relocation of tailings removed a significant amount of near-field "mineralized" contamination (e.g., cadmium, nickel and some of the uranium).

\section{$\underline{\mathrm{CO}_{2}} \underline{\text { Degassing }}$}

Groundwater is often at equilibrium with a substantially greater partial pressure of $\mathrm{CO}_{2}$ than is present in the atmosphere. If the partial pressure of $\mathrm{CO}_{2}$ in the vadose zone is less than is in equilibrium with groundwater, $\mathrm{CO}_{2}$ will degas from groundwater at the water table. This is more likely where the water table is shallow and diffusion and barometric pumping minimize build-up of $\mathrm{CO}_{2}$ from microbial processes in the vadose zone.

In calcareous aquifers, degassing of $\mathrm{CO}_{2}$ causes precipitation of calcite at the water table by the reaction:

$$
\mathrm{Ca}^{+2}+2 \mathrm{HCO}_{3}^{-}-\mathrm{CO}_{2(\mathrm{~g})}=\mathrm{CaCO}_{3}+\mathrm{H}_{2} \mathrm{O}
$$

In this reaction, dissolved uranium will coprecipitate with calcite in trace amounts. If the groundwater is near saturation with a uranium mineral, the uranium phase will precipitate because the loss of $\mathrm{CO}_{2}$ reduces the amount of carbonate available to complex uranium and keep it in solution. As an example, figure 17 shows a simulation of $\mathrm{CO}_{2}$ degassing using the composition of groundwater from well 0789 sampled in September of 2013 and varying the calculated $\log \mathrm{CO}_{2}$ partial pressure from -1.5 (the value calculated for the sample) to -3.5 (atmospheric). This simulation and all following geochemical simulations were done using The Geochemist’s Workbench ${ }^{\circledR}$ (Bethke and Yeakel, 2012). The saturation indices for three common 
uranium(VI) minerals increase as the partial pressure of $\mathrm{CO}_{2}$ decreases. Soddyite $\left[\left(\mathrm{UO}_{2}\right)_{2}\left(\mathrm{SiO}_{4}\right) \cdot 2 \mathrm{H}_{2} \mathrm{O}\right]$ becomes saturated and may precipitate at a $\mathrm{CO}_{2}$ partial pressure of 0.003 atm.

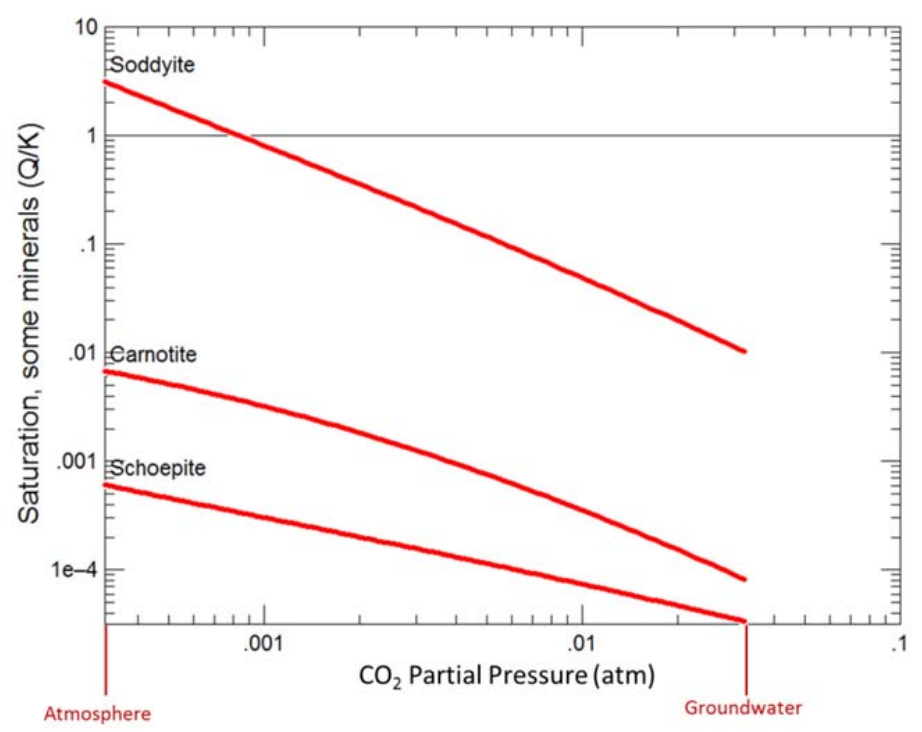

Figure 17: Simulation of the effect of $\mathrm{CO}_{2}$ degassing on uranium mineral saturation indices using an initial groundwater composition from well 0789 sampled in September 2013; alterations to the composition are as follows - dissolved calcium was replaced by calcite to simulate the calcareous aquifer and dissolved concentrations of silica $(16 \mathrm{mg} / \mathrm{L})$ and vanadium $(0.01 \mathrm{mg} / \mathrm{L})$ were added.

If uranium mineral precipitation from $\mathrm{CO}_{2}$ degassing does occur at the water table, it may be important in semi-arid environments where water tables may fluctuate significantly. When the water level in the aquifer rises, the mineralized zone is submerged into groundwater that has maintained elevated partial pressures of $\mathrm{CO}_{2}$. This can redissolve the uranium phase resulting in temporarily elevated concentrations of dissolved uranium.

\section{Mineralization from Evapotranspiration}

In semi-arid environments as described in the previous section, significant amounts of groundwater are lost from the water table aquifer by evapotranspiration. This process consists of direct evaporation of groundwater because of the low relative humidity in the vadose zone and loss of water to roots of phreatophyte plants (discussed above). Evapotranspiration can result in mineralization at the capillary fringe. As water is removed from the system, concentrations of dissolved constituents increase in the capillary fringe and minerals precipitate. Figure 18 shows a simulation of evaporation of $1 \mathrm{~kg}$ of solution with the composition of groundwater from well 0789 sampled in September 2013. Two simulations of evaporation were done with two different thermodynamic databases. The initial simulation (A) used the thermodynamic database "thermo.dat" because it contains uranium, silica and other constituents of interest. At the high ionic strength required for near complete evaporation the ion interaction model imbedded in 
"thermo.dat" becomes inaccurate. Thus, evaporation of the final 1\% of the water (B) was done using the thermodynamic database "thermo_hmw.dat” based on Harvie et al. (1984). Uranium is not included in this database, and thus no uranium minerals appear in Figure 18B.
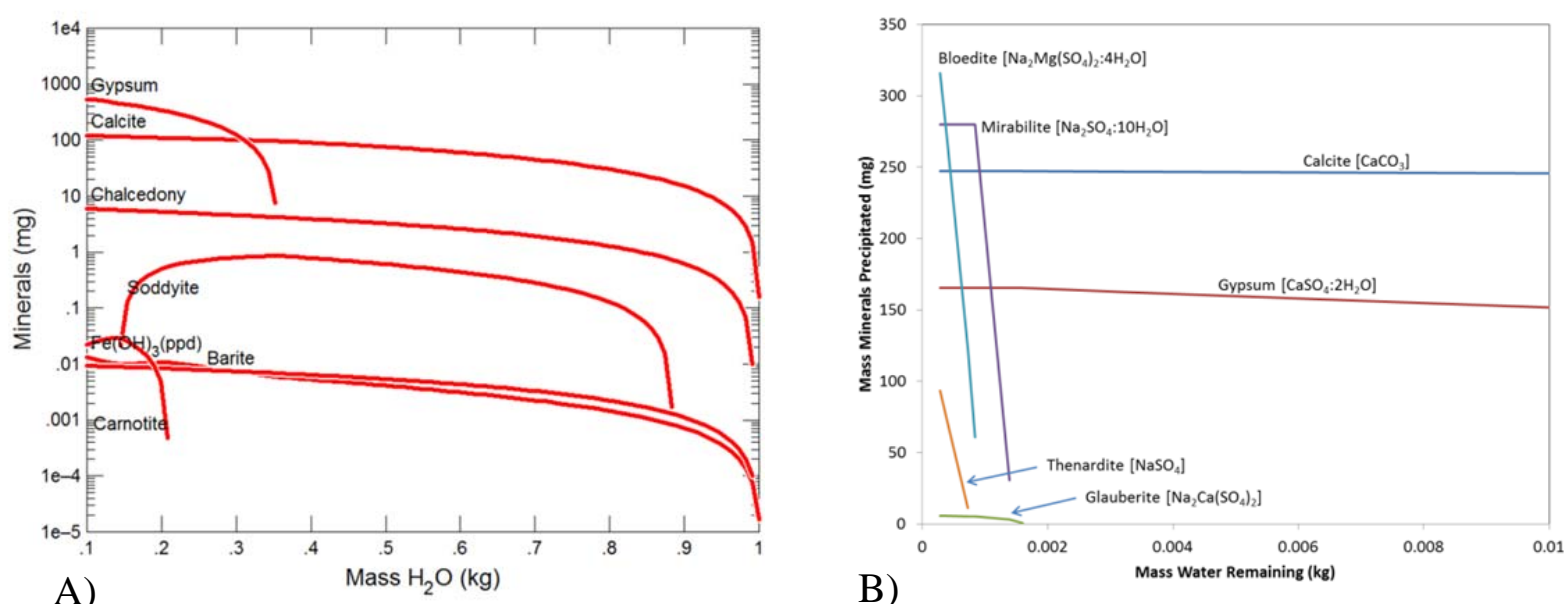

Figure 18: Simulation of evaporation of water from well 0789; A) first $90 \%$ of evaporation, B) final $1 \%$ of evaporation.

The simulation illustrates the types of minerals and their sequence of precipitation during evaporation. Initially minerals at saturation precipitate, in this case calcite, chalcedony, barite, and $\mathrm{Fe}(\mathrm{OH})_{3}$. At about $10 \%$ evaporation soddyite precipitates and gypsum begins to precipitate at $65 \%$ evaporation $(0.35 \mathrm{~kg}$ $\mathrm{H}_{2} \mathrm{O}$ remaining). With $0.21 \mathrm{~kg}$ of water remaining in the solution, carnotite precipitates shortly after soddyite stops precipitating. Evaporation of the final 1\% of the solution (Figure 18A) is dominated by continued precipitation of calcite and gypsum and in the final $0.02 \%$ the sodium sulfate minerals glauberite, mirabilite, bloedite, and thernardite precipitate.

The sequence of minerals is dictated by their relative solubilities, with highly soluble minerals precipitating last. Dissolution of an evaporite deposit would tend to follow the reverse sequence resulting initially in high concentrations of sodium and sulfate. Likewise, precipitation of uranium minerals would follow a similar sequence with the bulk of the uranium precipitated in relatively low solubility minerals. The final uranium minerals to precipitate would likely be soluble sulfate phases. Uranium would also coprecipitate to some degree in other minerals.

Key Points

- Various reactions in the vicinity of the water table, such as degassing of $\mathrm{CO}_{2}$ and evaporation of water, will result in precipitation of solid mineral phases

- Thermodynamic calculations indicate that the major minerals would include evaporites such as calcite, gypsum, and Blödite that will precipitate in a sequence depending on the local conditions and the amount of evaporation - Uranium is predicted to form accessory minerals such as soddyite (uranium silicate) and carnotite . 


\section{Ion Exchange}

Ion exchange, mostly on the surfaces of clay-sized minerals, changes the bulk chemistry of groundwater. Cation exchange is more widely considered than anion exchange, but both can occur. In a calcareous aquifer, the cation exchange sites are saturated with $\mathrm{Ca}^{+2}$ ions. When sodium-rich leachate, for example from the tailings pile, migrates into the aquifer $\mathrm{Na}^{+}$ions will exchange for $\mathrm{Ca}^{+2}$ ions. This lowers the concentration of sodium in groundwater along a flow path. Calcium concentrations may be buffered by precipitation of calcite, and thus inverse correlation between calcium and sodium concentrations may not exist along the flow path. As the source of sodium to the groundwater is depleted and sodium concentrations decrease, the reverse reaction may occur leading to prolonged flushing of sodium from the system. Magnesium may also exchange for $\mathrm{Na}^{+}$or $\mathrm{Ca}^{+2}$ at mineral surfaces. Magnesium was often used in the uranium milling process (Clark, 1974) and was released in leachate from tailings piles.

Ion exchange is controlled by the cation and anion exchange capacities of the sediment, which are generally related to the clay content and mineralogy. Natural organic matter can also contribute significant exchange capacity for both cations and anions.

Ion exchange is not currently influencing the bulk groundwater chemistry. Figure 19 shows a positive, though poor correlation between dissolved sodium and calcium in the groundwater, indicating no significant exchange of sodium from the groundwater for calcium at mineral surfaces. Likewise, the excellent correlation between sodium and sulfate in Figure 20 indicates little loss of $\mathrm{Na}$ from the groundwater relative to sulfate. These trends suggest the site has reached a steady-state where exchange sites are saturated with sodium.

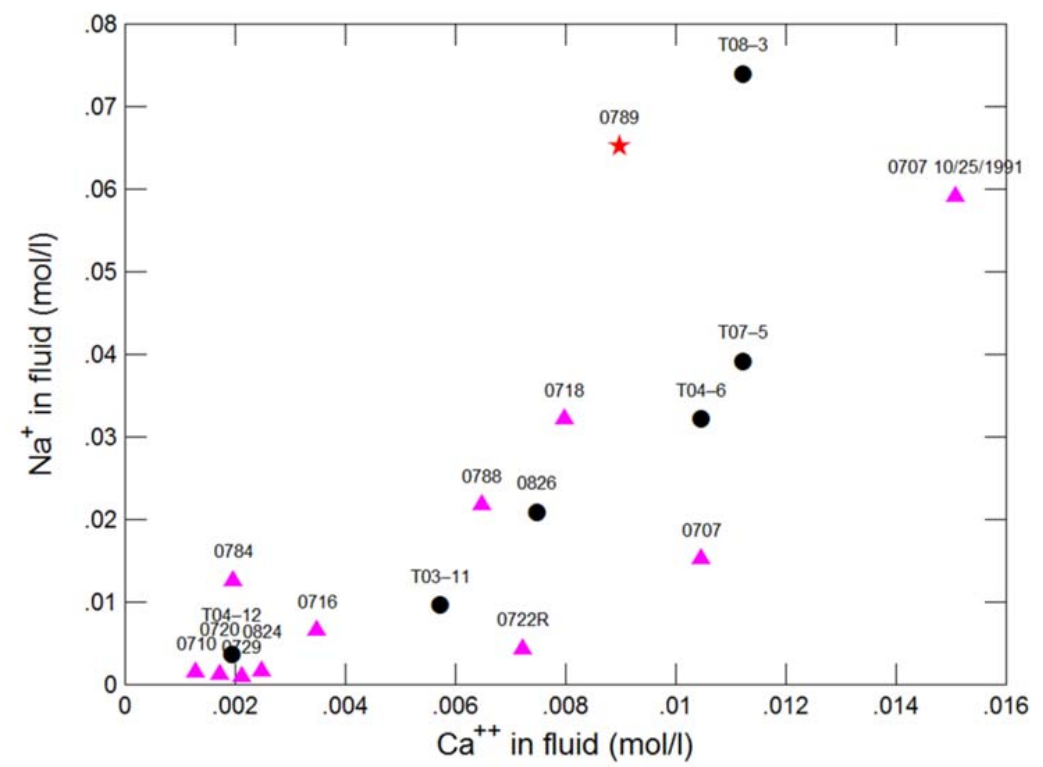

Figure 19: Sodium versus calcium in groundwater from the Riverton site ((triangles = well data, closed circles $=$ GeoProbe data, star $=$ well 0789). 


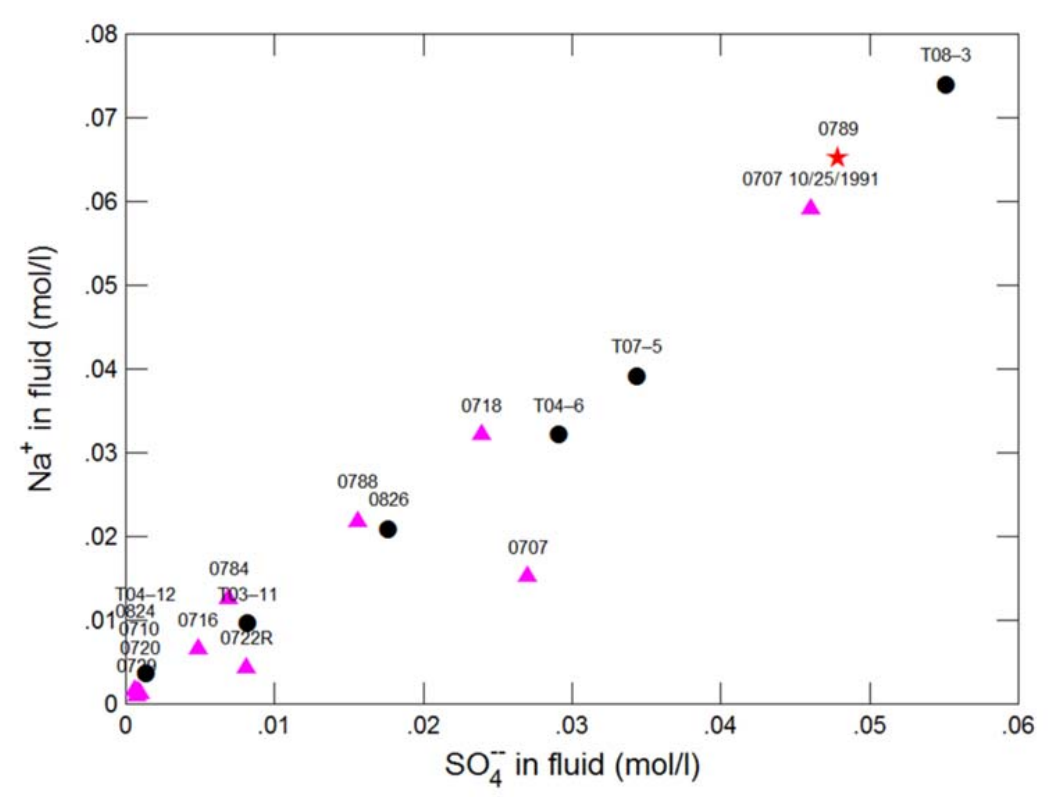

Figure 20: Sodium versus sulfate in groundwater from the Riverton site ((triangles = well data, closed circles $=$ GeoProbe data, star $=$ well 0789).

\section{Diffusion into Low Permeability Zones}

Prolonged flushing of all constituents associated with the tailings pile may result from diffusion of these constituents into zones with relatively low permeability. This has long been studied, particularly in relation to remediation of organic contaminants (e.g., NAS, 1994; Seyedabbasi et al., 2012). As the source of the plume is depleted and plume-related constituents are flushed from higher permeability zones, back diffusion of these constituents from lower permeability zones will prolong the flushing process.

\section{$\underline{\text { Interactions with Natural Organic Matter }}$}

Uranium interacts with organic matter in two ways - adsorption or reduction of U(VI) to U(IV) followed by precipitation of the sparingly soluble U(VI). An enormous body of literature documents the association of uranium with natural organic matter, from the early recognition of uranium ore bodies replacing organic material to recent studies of contaminant uranium transport. The most pertinent studies relative to the Riverton site are recent studies of natural reducing zones (NRZ) at the Rifle site (e.g., Qafoku et al., 2009; Bargar et al., 2011; Campbell et al., 2012; Zachara et al., 2013). The geology of the Rifle site is similar to that of the Riverton site, i.e., dominated by fluvial deposits. Uranium, mostly as U(IV), has been observed in the naturally reduced zones (Bargar et al., 2011; Campbell et al., 2012). The sediments in these zones contain higher concentrations of natural organic matter, and the sequestration of uranium has been likened to miniature roll-front deposits (Campbell et al., 2012). Similar natural reducing zones are likely to occur at the Riverton site. NRZ are addressed in more detail below. 
Geochemical Processes and Heterogeneity

In an aquifer composed of fluvial alluvium, the extent of the processes discussed above varies spatially because of the high heterogeneity characteristic of this lithologic unit. Figure 21 diagrams the lithologic facies surrounding a typical cut off meander on the Mississippi River. Similar lithologic heterogeneities can be seen in the satellite image of the Riverton site (Figure 22) that shows numerous old cut off meanders that would have associated point bars, filled oxbow lakes, channel fill, and overbank deposits. This suggests a wide range of subsurface lithology ranging from organic-rich muds to cobbles mixed in various sequences and orientations as the Wind River and Little Wind River evolved. The lithologic heterogeneity translates into geochemical heterogeneity because of spatial variation in clay and organic content, as well as in the hydraulic properties of the sediments. For example, channel-fill deposits will have lower clay content, and will contain less reactive organic matter than overbank or flood basin deposits. Hence, contaminant adsorption and ion exchange will be less in channel deposits than in over bank deposits. Another example would be the difference in the capillary fringe when the water table intersects a gravel channel-fill or point bar deposit compared to when it intersects clayey overbank deposit. The capillary fringe will be thin in a gravel deposit relative to a more clay-rich or fine sand deposit. Thus, mineralization at the capillary fringe due to $\mathrm{CO}_{2}$ degassing or evaporation will be confined to a thin zone in a coarse grained deposit, but may be spread over a thicker zone in fine-grained deposits.

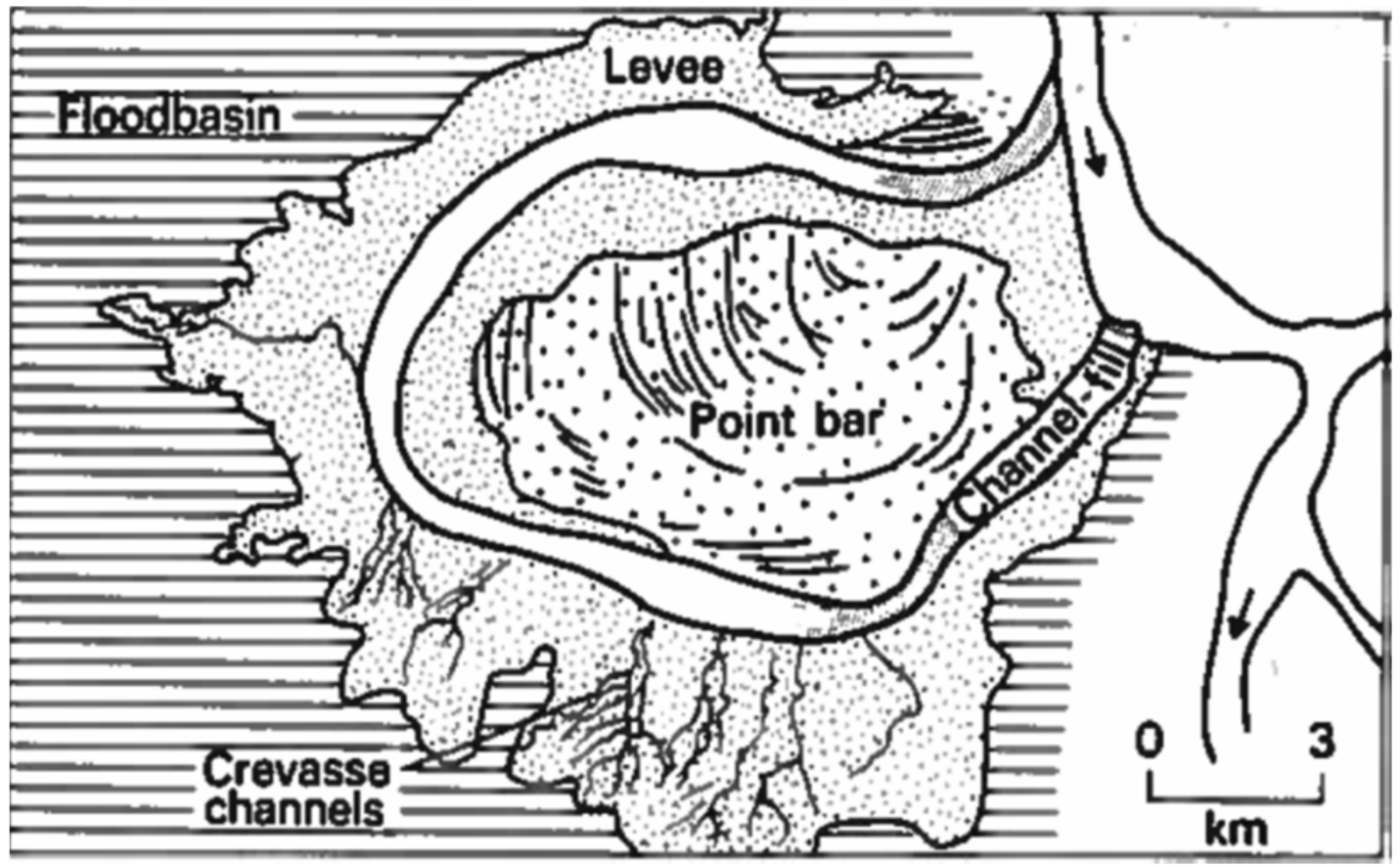

Figure 21: Diagram of lithologic facies associated with a cut off meander on the Mississippi River (from Collinson, 1986; after Fisk, 1947). 


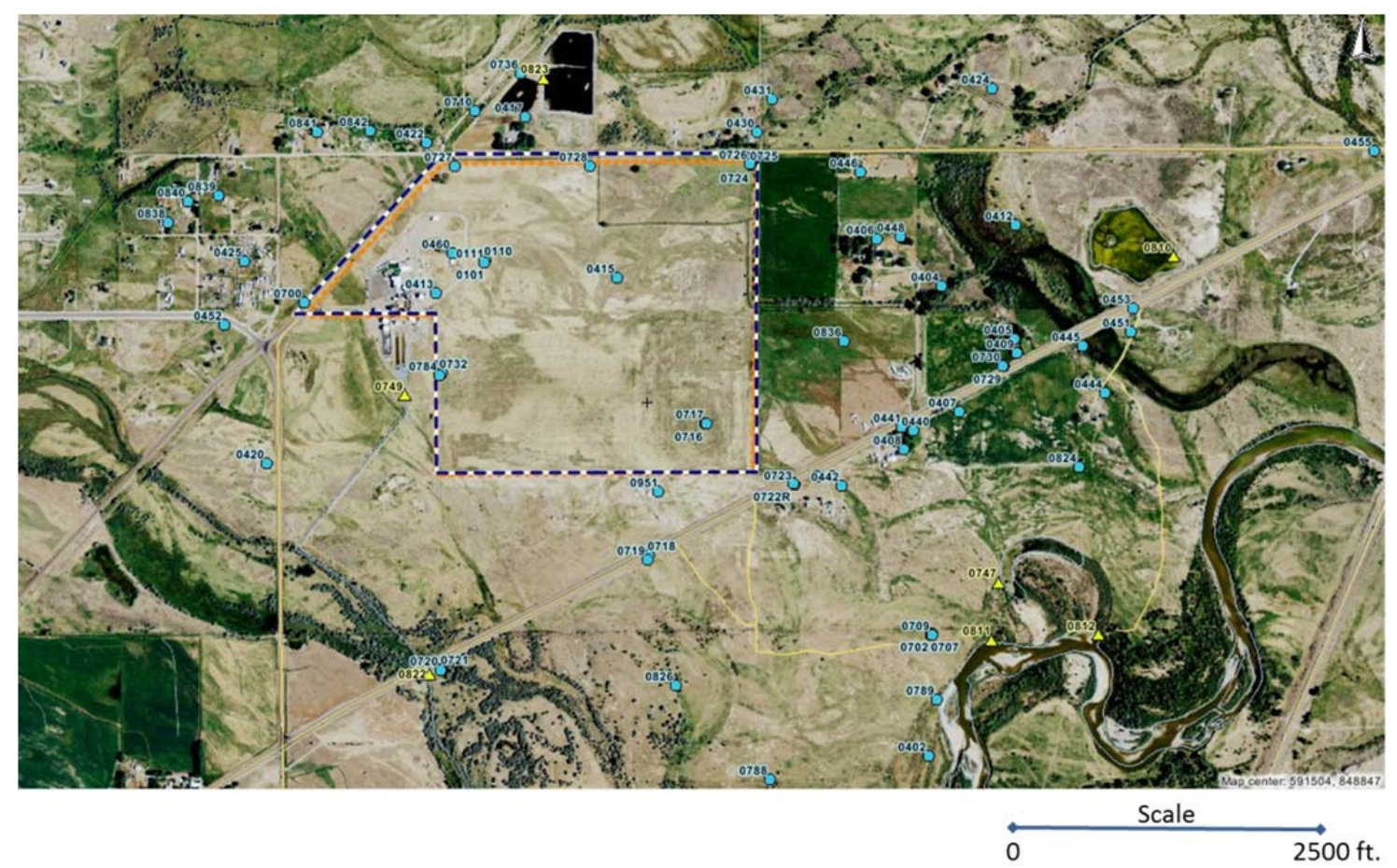

Figure 22: Satellite image of the Riverton Site (from DOE, 2013).

\section{$\underline{\text { Geochemical Processes at the Riverton Site Based on Groundwater Chemistry Trends }}$}

Trends observed in the bulk chemistry of the Riverton site groundwater and the behavior of several contaminants suggest that several geochemical processes are active today. The processes can be identified by analysis of the analytical results for groundwater sampling events through time and space. This analysis uses data from the September 2013 well and surface water sampling event. In addition, 5 sample analyses from the 2012 enhanced characterization Geoprobe data (DOE, 2013) were used - T03-11, T04-6, T04-12, T07-5, and T08-3. These were selected because they were within the plume and near monitoring wells. Also included on many figures is data from a well 0707 sample obtained on 10/25/1991. This sample was influenced by the 1991 flood of the Little Wind River and shows spikes in contaminant concentrations. It was chosen because it was the only complete sample analysis available that was influenced by a known flood.

The composition of the groundwater within the plume at the Riverton site is similar to contaminated groundwater at other UMTRCA sites. It is dominated by sulfate and sodium, with elevated concentrations of chloride, magnesium, and calcium. The groundwater is saturated with calcite, but for the most part, undersaturated with gypsum. Figure 23 shows the calculated saturation indices (Log Q/K) for calcite and gypsum. 


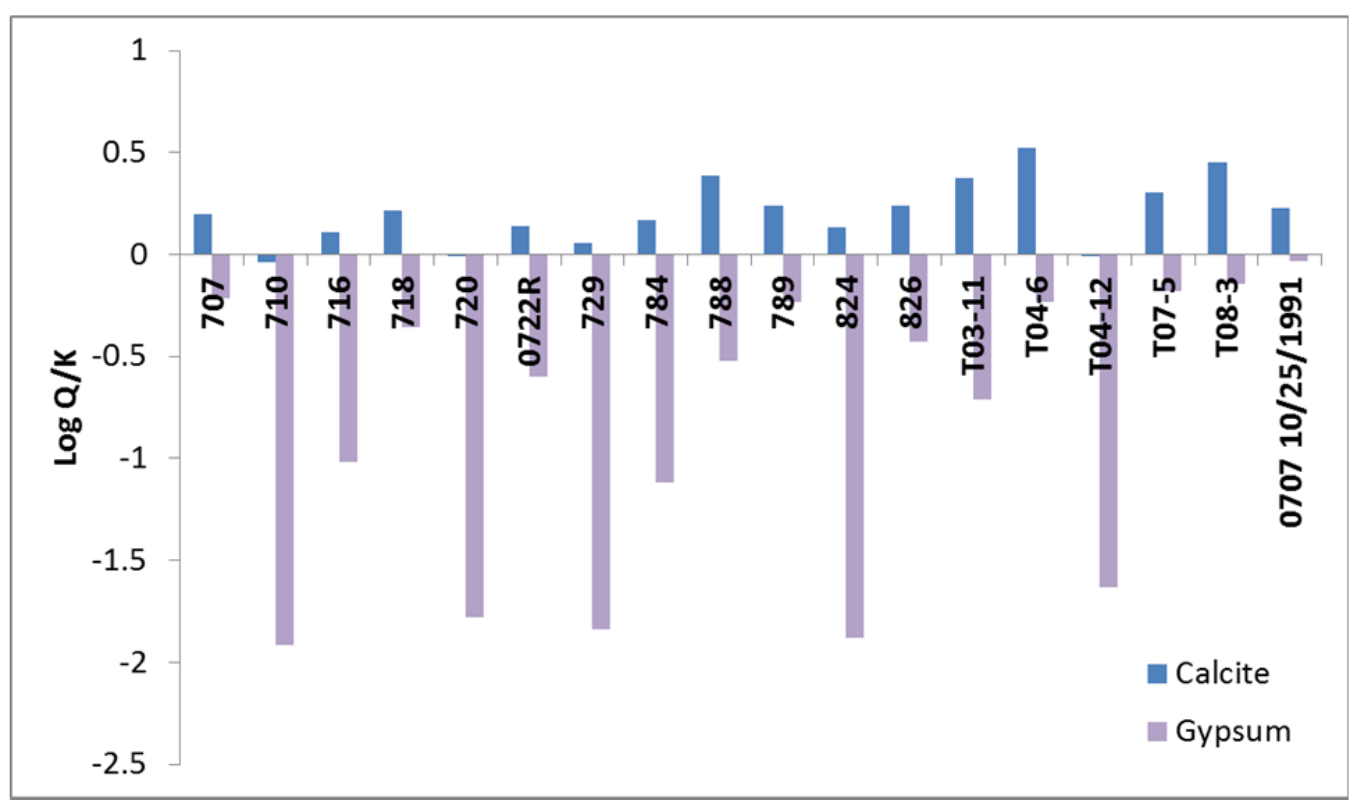

Figure 23: Saturation indices ( $\log \mathrm{Q} / \mathrm{K})$ for calcite and gypsum in groundwater at the Riverton site (sampled in September 2013).

\section{Natural Reducing Zones and Microbial Activity}

Given the similarity between the Riverton site geologic setting and the Rifle Site, it is expected that NRZ exist at the Riverton Site. Thus far, there is no concrete evidence to indicate the presence of these zones, and they do not appear to be significantly attenuating contaminants. However, the calculated partial pressures of $\mathrm{CO}_{2}\left(\mathrm{PCO}_{2}\right)$ in equilibrium with the groundwater are high. Figure 24 shows the calculated $\mathrm{PCO}_{2}$ versus sulfate for the groundwater samples. Most values are between 0.03 and 0.04 , approximately 100 times atmospheric $\mathrm{CO}_{2}$ partial pressure (3.2E-4 atm). The high values are in the upper range of natural groundwater $\mathrm{PCO}_{2}$ values. Narasimhan et al. (1982) measured high $\mathrm{CO}_{2}$ in soil gas beneath the tailings pile and attributed it to dissolution of calcite by the acidic tailings leachate. However, this explanation is not applicable to current groundwater found down gradient from the former tailings pile. It is more likely that microbial activity accounts for the high $\mathrm{PCO}_{2}$ values. Whether the microbial activity is related to natural reducing zones is not known. The groundwater is not reducing. Figure 25 shows where the monitoring well data and GeoProbe data from transects T04 and T08 plot on an Eh-pH diagram of iron speciation. They lie along the equiactivity line between ferric and ferrous iron. Dissolved oxygen is low, $0.5-1 \mathrm{mg} / \mathrm{L}$, in the GeoProbe samples, but not indicative of reducing conditions. It is interesting that the background location, well 0710, has a lower $\mathrm{PCO}_{2}$ value and that the sample from well 0784, near the sulfuric acid plant effluent ditch, has the lowest $\mathrm{PCO}_{2}$ value. Soil gas measurement of $\mathrm{CO}_{2}$ and analysis of the stable carbon isotopes might shed more light on the origin of the elevated $\mathrm{PCO}_{2}$ values and/or the presence of NRZ. 


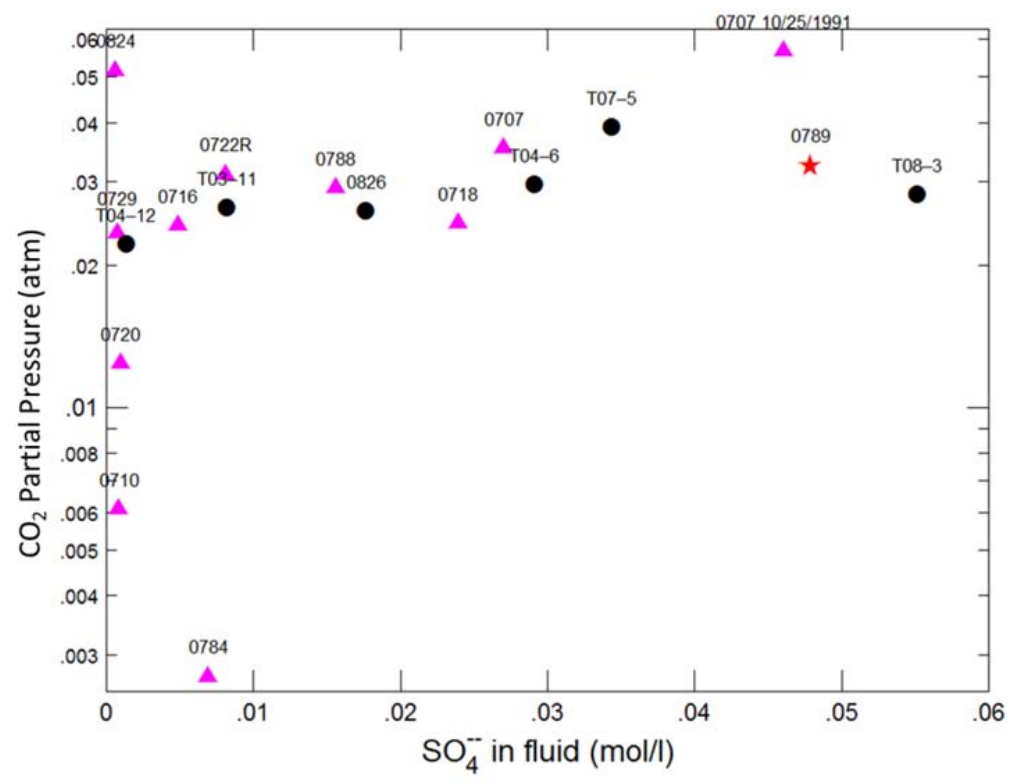

Figure 24: Calculated partial pressure of $\mathrm{CO}_{2}$ versus sulfate in Riverton site groundwater (triangles $=$ well data, closed circles $=$ GeoProbe data, star $=$ well 0789).

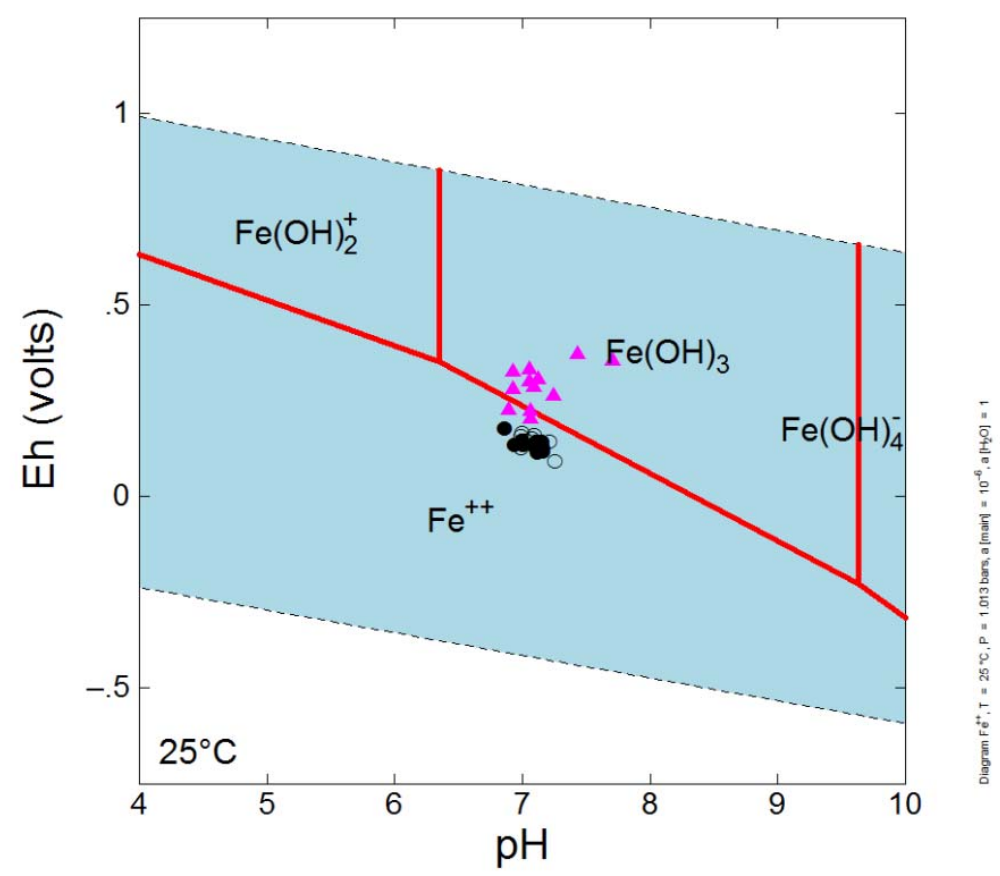

Figure 25: Eh-pH diagram of iron speciation showing Eh-pH values for Riverton site groundwater (triangles $=$ well data, closed circles $=$ GeoProbe data transect T04, open circles $=$ GeoProbe data transect T08). 


\section{Capillary Fringe Processes}

Mineralization from evapotranspiration and degassing of $\mathrm{CO}_{2}$ are capillary fringe processes and are difficult to distinguish from analysis of groundwater chemistry, thus, they are discussed together here. If these processes are occurring, they are producing soluble minerals within the capillary fringe, such that when the water table rises some fraction of these minerals will dissolve, releasing sulfate, associated counter ions, and potentially contaminants to the groundwater. Time trends are shown in Figures 26 and 27 for water table elevation, uranium molybdenum, and sulfate in groundwater from wells 0707 and 0789. In well 0707, the two highest elevations reached by the water table correspond to effects from the floods of 1991 and 2010. These are accompanied by spikes in the concentrations of uranium, molybdenum, and sulfate. An additional elevated water table event in May of 1999 correlates with a small increase in sulfate concentration, but not uranium and molybdenum. There is not a perfect correlation between water table elevation and increased concentrations of sulfate, uranium, and molybdenum. Yet, during times of known flooding there is an increase in these constituents.

There is a much shorter monitoring period for well 0789, but it shows the same trends for the flood of 2010. The elevated water table is accompanied by a sharp increase in sulfate, uranium, and molybdenum concentrations (Figure 27).

The sulfate concentrations in both wells are fairly constant in the time before the first flood (1991 for 0707; 2010 for 0789). The concentration in well 0707 is near $3000 \mathrm{mg} / \mathrm{L}$ from 1985 until the flood in 1991 when it increases to $4430 \mathrm{mg} / \mathrm{L}$. In well 0789 the sulfate concentration is near $4000 \mathrm{mg} / \mathrm{L}$ from 2006 until the flood in 2010 when it increases to $9700 \mathrm{mg} / \mathrm{L}$. The specific conductance of the groundwater in well 0707 reflects a corresponding increase (Figure 28), indicating the high sulfate values are not in error. Specific conductance in well 0789 also reflects the peak sulfate concentrations. Reaction path modeling with The Geochemist's Workbench ${ }^{\circledR}$ indicates that the concentration of sulfate in equilibrium with gypsum and calcite is between 3000 and $5000 \mathrm{mg} / \mathrm{L}$, depending on $\mathrm{PCO}_{2}$ and $\mathrm{pH}$. The sulfate concentration of $9700 \mathrm{mg} / \mathrm{L}$ must come from dissolution of a more soluble sulfate mineral like those precipitated during evaporation of the groundwater. 


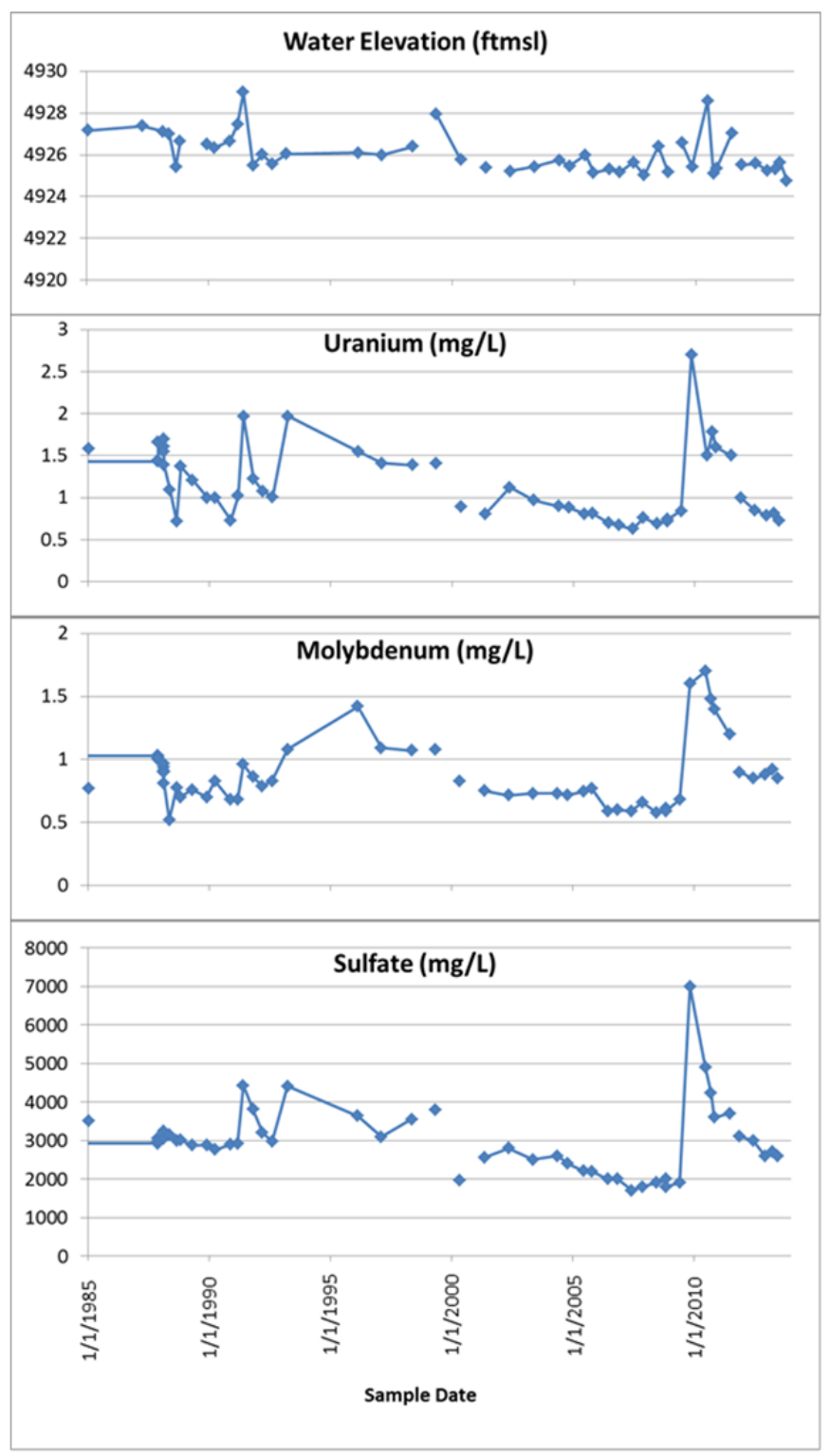

Figure 26: Time trends for water table elevation, uranium, molybdenum, and sulfate in well 0707 


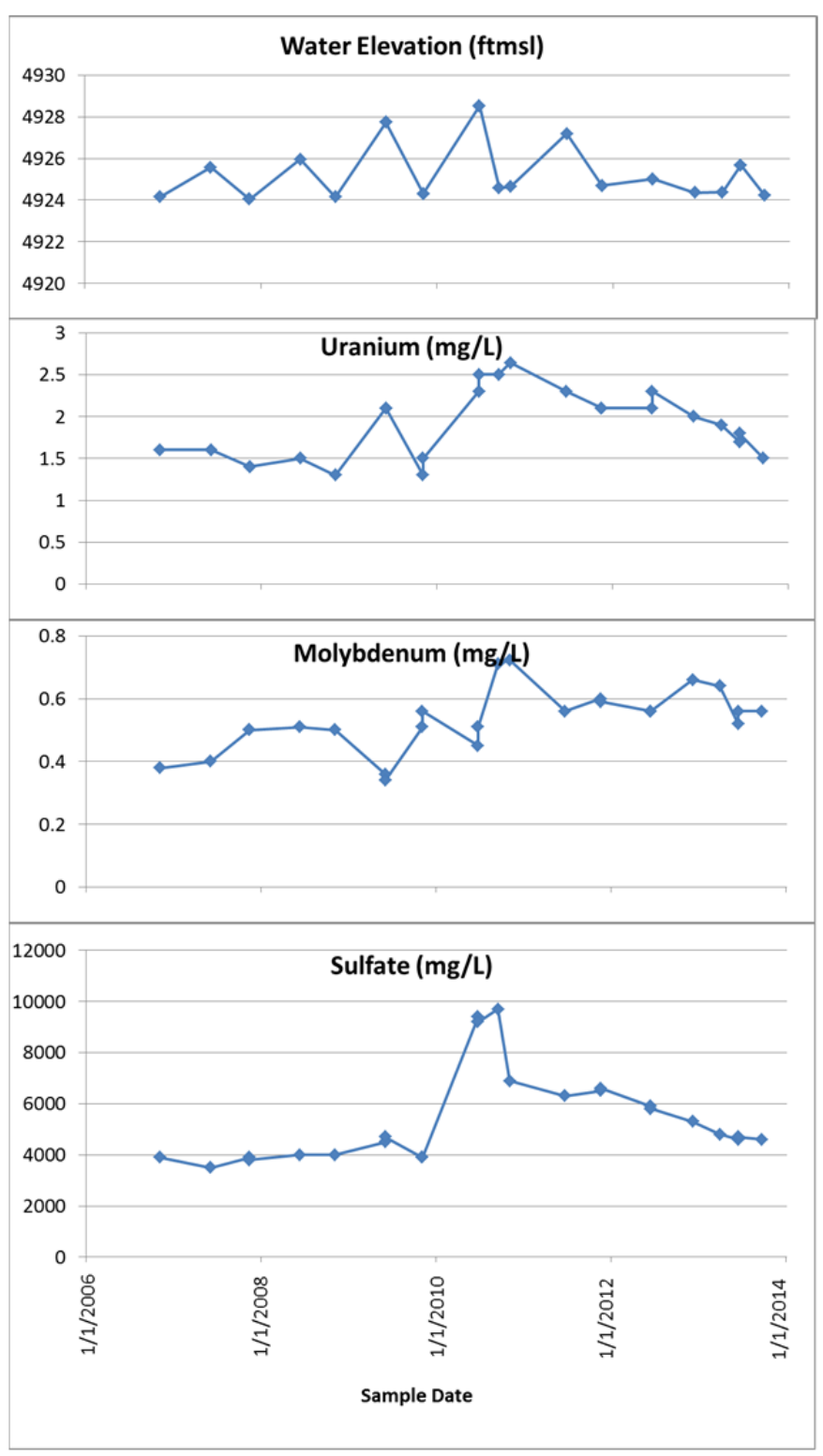

Figure 27: Time trends for water table elevation, uranium, molybdenum, and sulfate in well 0789 


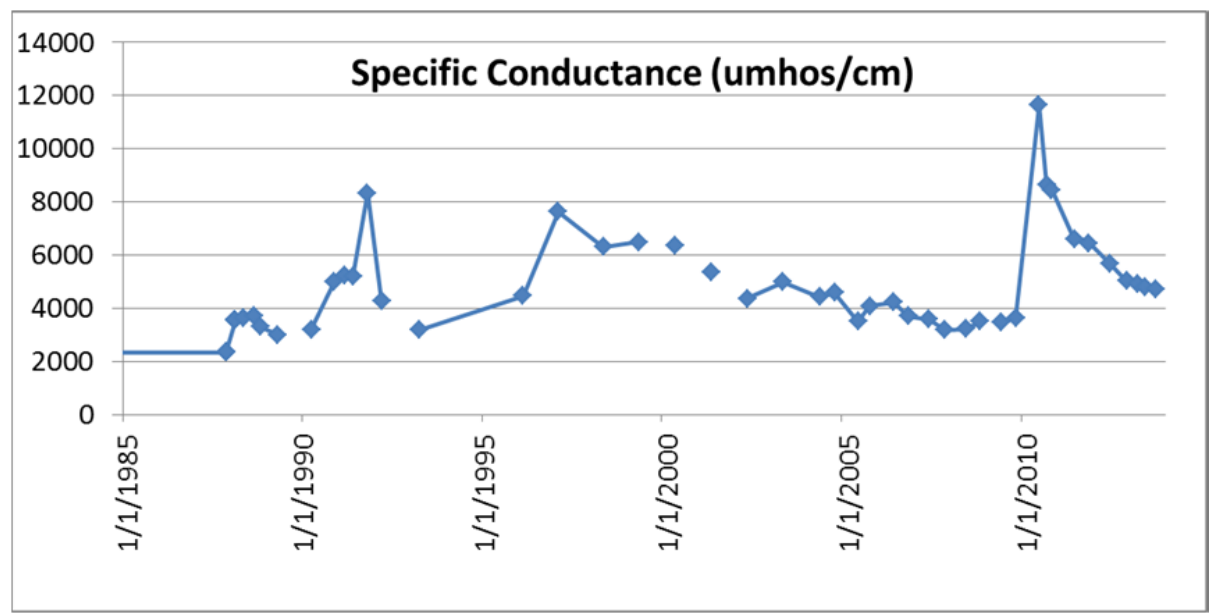

Figure 28: Time trend of specific conductance in well 0707.

\section{Field Evidence of Evaporitic Deposits}

An efflorescent and solid mineral deposit occurs along the embankment where the groundwater plume crops out at the Little Wind River. A scoping sample of the efflorescence/encrustation was collected from the escarpment and placed in a ziplock bag (Figure 29). The sample was prepared for transport by scraping off adhered soil using a plastic spoon. Following receipt in the laboratory, the sample was dried at $65 \mathrm{C}$ for 24 hours, disaggregated in a mortar and pestle, and sieved to remove roots and debris. The process was repeated until the white material was all reduced to a powder. The powder sample was then analyzed using two techniques: 1) X-ray fluorescence (XRF) to determine the elemental composition, and 2) x-ray diffraction (XRD) to determine the primary minerals present. 

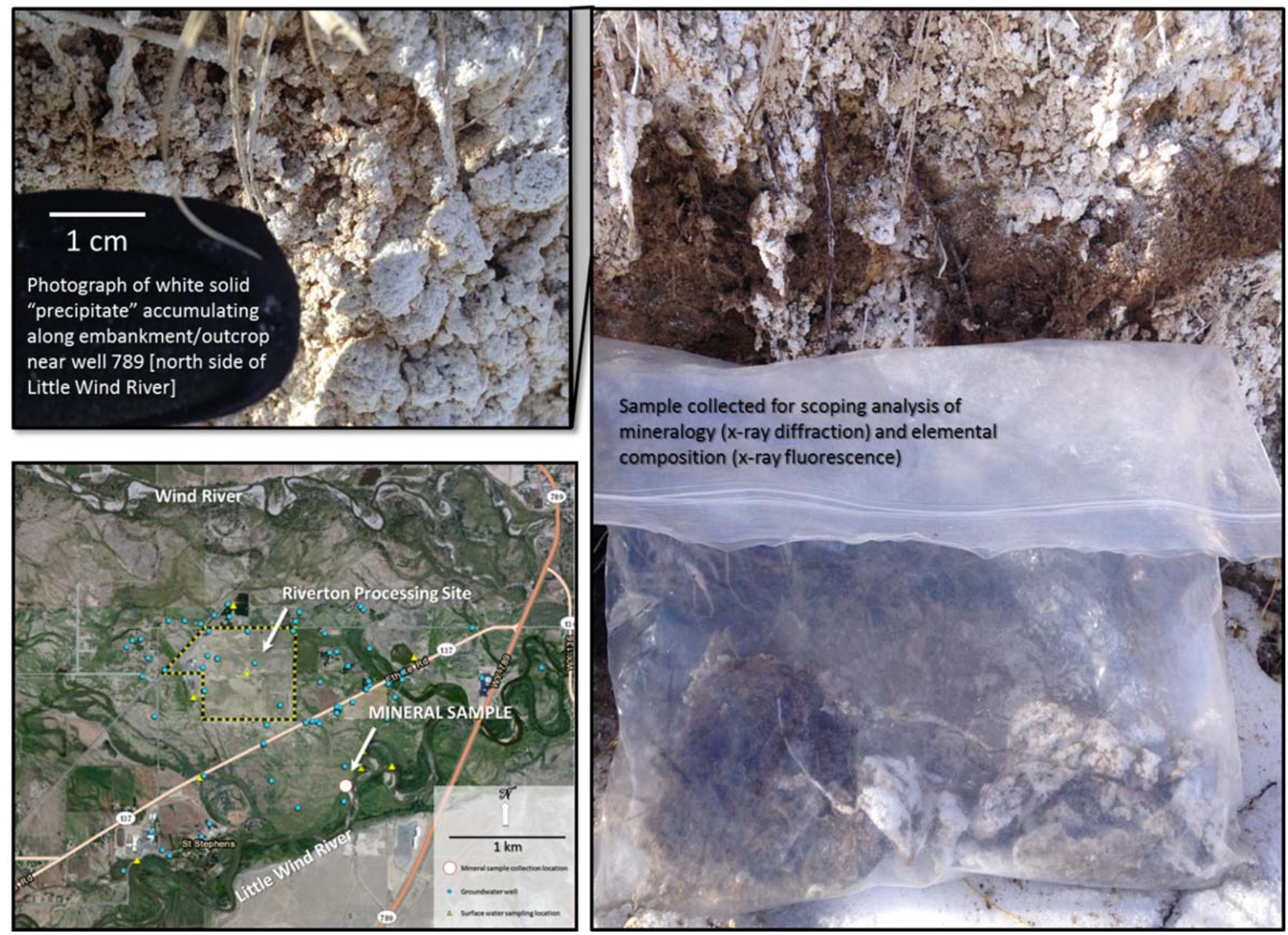

Figure 29. Top left and right, photographs of white evaporite mineral deposits observed along the escarpment at the Little Wind River. Left, the location map for photographs and sample collection.

Two instruments were employed for the XRF analysis, a portable unit (Niton XL3t) and a laboratory unit (Spectro XLAB 2000). Both were run using the powder sample. The laboratory instrument uses a helium atmosphere and is capable of accurately quantifying light elements. Thus, the laboratory instrument provides reasonable quantification of elements down to sodium (i.e., provides quantitative information for $\mathrm{Na}, \mathrm{Mg}, \mathrm{Al}, \mathrm{Si}, \mathrm{P}, \mathrm{S}, \mathrm{Cl}, \mathrm{K}, \mathrm{Ca}$ and above). The portable instrument does not quantify $\mathrm{Na}$, provides qualitative information for Mg, Al, Si, P. S, $\mathrm{Cl}$ and $\mathrm{K}$, and provides reasonable quantification for $\mathrm{Ca}$ and above. Both instruments provide high quality quantitative data for trace elements such as $\mathrm{U}, \mathrm{As}, \mathrm{Pb}, \mathrm{Se}$, etc. The results for the XRF analyses are shown in Table 2. 
Table 2. Chemical composition (XRF data) of the bulk Riverton WY evaporite scoping sample collected from the escarpment near well 789

\begin{tabular}{|c|c|c|}
\hline Element & LAB XRF & PORTABLE XRF \\
\hline $\bar{S}$ & $188591 \mathrm{ppm}$ & 82000 ppm \\
\hline $\mathrm{Na}$ & $162022 \mathrm{ppm}$ & -- \\
\hline Si & 77735 ppm & 44100 ppm \\
\hline $\mathrm{Cl}$ & $52845 \mathrm{ppm}$ & 49700 ppm \\
\hline Mg & $47759 \mathrm{ppm}$ & $13400 \mathrm{ppm}$ \\
\hline $\mathrm{Ca}$ & $21125 \mathrm{ppm}$ & 12600 ppm \\
\hline Al & $14328 \mathrm{ppm}$ & $4720 \mathrm{ppm}$ \\
\hline $\mathrm{Fe}$ & $6150 \mathrm{ppm}$ & $2800 \mathrm{ppm}$ \\
\hline $\mathrm{K}$ & $\begin{array}{ll}- \\
-\end{array}$ & $3360 \mathrm{ppm}$ \\
\hline$P$ & $1612 \mathrm{ppm}$ & $<400 \mathrm{ppm}$ \\
\hline $\mathrm{Ti}$ & $380 \mathrm{ppm}$ & $472 \mathrm{ppm}$ \\
\hline $\mathrm{Ba}$ & $271 \mathrm{ppm}$ & $<32 \mathrm{ppm}$ \\
\hline $\mathrm{Zr}$ & 208 ppm & $120 \mathrm{ppm}$ \\
\hline $\mathrm{Sr}$ & $194 \mathrm{ppm}$ & 100 ppm \\
\hline $\mathrm{Mn}$ & $132 \mathrm{ppm}$ & $44 \mathrm{ppm}$ \\
\hline $\mathrm{Br}$ & $91 \mathrm{ppm}$ & -- \\
\hline$U$ & $64 \mathrm{ppm}$ & 73 ppm \\
\hline Sc & -- & $46 \mathrm{ppm}$ \\
\hline Co & 40 ppm & $<32 \mathrm{ppm}$ \\
\hline $\mathrm{Rb}$ & $27 \mathrm{ppm}$ & $20 \mathrm{ppm}$ \\
\hline $\mathrm{Ce}$ & $25 \mathrm{ppm}$ & -- \\
\hline $\mathrm{La}$ & $25 \mathrm{ppm}$ & -- \\
\hline Mo & $25 \mathrm{ppm}$ & -- \\
\hline $\mathrm{Ni}$ & $25 \mathrm{ppm}$ & $<22 \mathrm{ppm}$ \\
\hline $\mathrm{Rb}$ & -- & $19 \mathrm{ppm}$ \\
\hline $\mathrm{W}$ & -- & $<40 \mathrm{ppm}$ \\
\hline $\mathrm{Te}$ & -- & $<26 \mathrm{ppm}$ \\
\hline $\mathrm{Cr}$ & -- & $<15 \mathrm{ppm}$ \\
\hline $\mathrm{Ag}$ & -- & $<15 \mathrm{ppm}$ \\
\hline $\mathrm{Au}$ & -- & $<15 \mathrm{ppm}$ \\
\hline $\mathrm{Pb}$ & $12 \mathrm{ppm}$ & $<3 \mathrm{ppm}$ \\
\hline $\mathrm{Zn}$ & $12 \mathrm{ppm}$ & $<6$ ppm \\
\hline $\mathrm{Y}$ & $11 \mathrm{ppm}$ & -- ppm \\
\hline Sn & -- & $<12 \mathrm{ppm}$ \\
\hline $\mathrm{Cs}$ & -- & $<11 \mathrm{ppm}$ \\
\hline $\mathrm{Cu}$ & -- & $<10 \mathrm{ppm}$ \\
\hline $\mathrm{V}$ & -- & $<10 \mathrm{ppm}$ \\
\hline $\mathrm{Sb}$ & -- & $<10 \mathrm{ppm}$ \\
\hline Th & $7 \mathrm{ppm}$ & $5 \mathrm{ppm}$ \\
\hline $\mathrm{Nb}$ & -- & $7 \mathrm{ppm}$ \\
\hline $\mathrm{Ga}$ & $6 \mathrm{ppm}$ & -- \\
\hline $\mathrm{Cd}$ & -- & $<6 \mathrm{ppm}$ \\
\hline $\mathrm{Hg}$ & -- & $<4 \mathrm{ppm}$ \\
\hline $\mathrm{Bi}$ & $3 \mathrm{ppm}$ & -- ppm \\
\hline $\mathrm{Se}$ & $3 \mathrm{ppm}$ & $<2 \mathrm{ppm}$ \\
\hline$P d$ & -- & $<3 \mathrm{ppm}$ \\
\hline $\mathrm{Bi}$ & -- & $<3$ ppm \\
\hline As & -- & $<2 \mathrm{ppm}$ \\
\hline $\mathrm{Re}$ & -- & $<2$ ppm \\
\hline $\mathrm{Ta}$ & -- & $<2$ ppm \\
\hline $\mathrm{Hf}$ & -- & $<2 \mathrm{ppm}$ \\
\hline
\end{tabular}

Notes: All data are reported as ppm

Bold $=$ major elements used to constrain quantitative interpretation of $\mathrm{xrd}$ mineralogy

Grey = qualitative

Italics = uranium

$---=$ not reported

Elements sorted by abundance 
The major elements present in the sample include $\mathrm{S}, \mathrm{Na}, \mathrm{Si}, \mathrm{Cl}, \mathrm{Mg}, \mathrm{Ca}, \mathrm{Al}$ and Fe. The uranium measured in the bulk sample was $64 \mathrm{ppm}$ and $73 \mathrm{ppm}$ for the lab instrument and portable instrument, respectively. These values are in the expected range for evaporatic minerals in the western United States, and secondary minerals accumulated in various zones along flow path would be expected to have similar uranium levels. The chemical composition of the sample is generally consistent with an evaporite mineral that accumulates over time, concentrating the constituents of the groundwater in a solid mineral form.

The XRD mineralogical characterization was performed using a Bruker D8 Advanced and the data are shown in Figure 30. The primary minerals identified in the sample included Halite ( $\mathrm{NaCl})$, quartz $\left(\mathrm{SiO}_{4}\right)$, Blödite $\left(\mathrm{Na}_{2} \mathrm{Mg}\left(\mathrm{SO}_{4}\right)_{2}: 4 \mathrm{H}_{2} \mathrm{O}\right)$, and Thenardite $\left(\mathrm{Na}_{2} \mathrm{SO}_{4}\right)$.

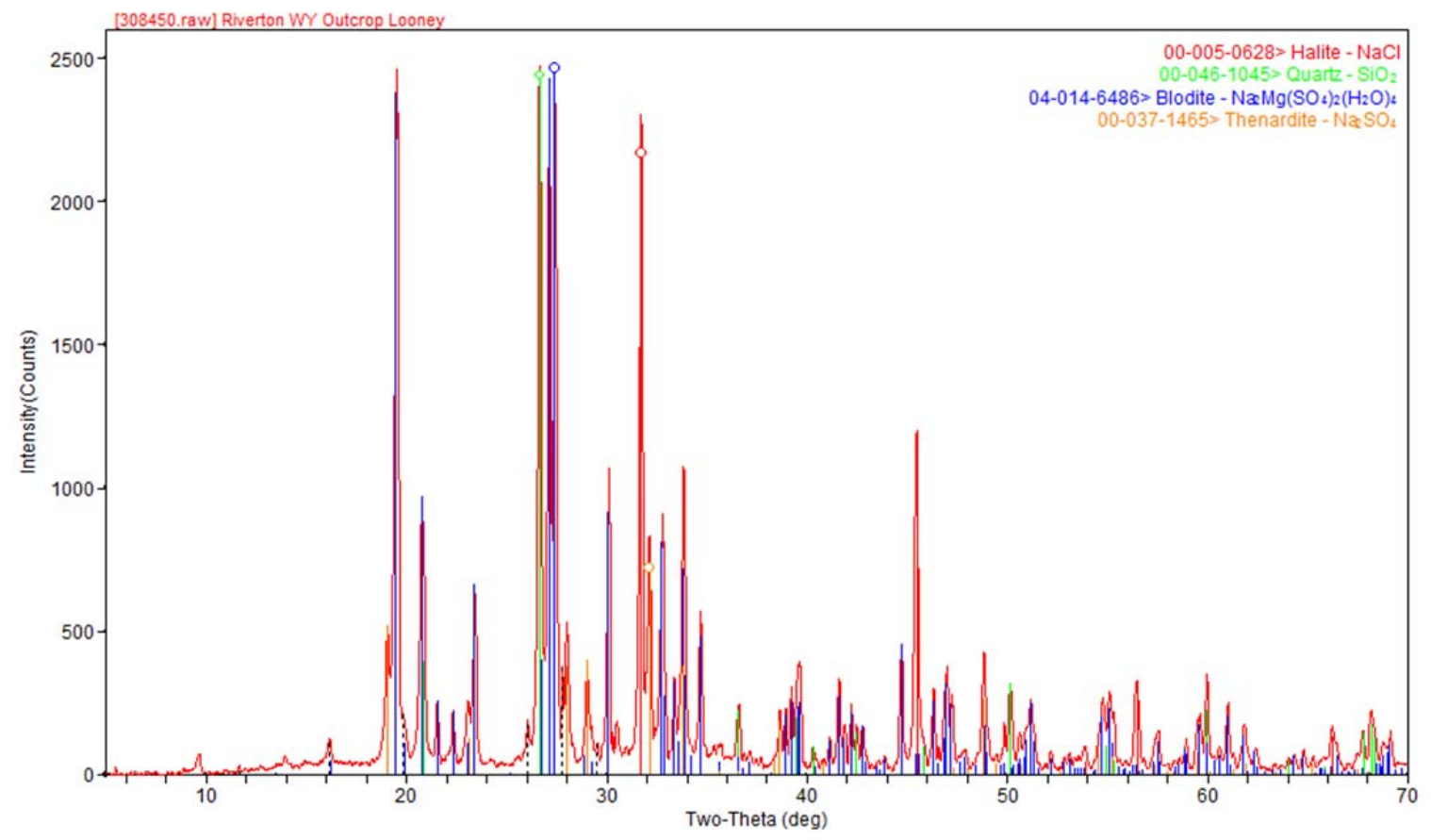

Figure 30. XRD results identifying the major minerals present in the Riverton WY evaporite scoping sample collected from the escarpment near well 789.

The approximate quantity of the different minerals can be refined and quantitatively estimated by incorporating the elemental composition. The combined XRD-XRF calculation uses the chemical formula for each identified mineral, the atomic weight of each element, and the measured elemental concentrations in the bulk sample. The amount, or fraction, of each mineral is then estimated using a multi-parameter best fit. The result for the raw sample is reported in Table 3 ("total normalized" column). The raw sample contained some soil (i.e., all of the soil could not be scraped off), so additional calculations/corrections were made to approximate the compositions of the white precipitate with no soil contribution. These corrections remove the predominant soil minerals $\left(\mathrm{SiO}_{2}, \mathrm{Al}_{2} \mathrm{O}_{3}\right.$ and $\left.\mathrm{Fe}_{2} \mathrm{O}_{3}\right)$ and scaled remaining mineral fractions to sum to a value of 1 . The data clearly document the predominance of sodium and magnesium sulfates. Additional mixed ( $\mathrm{Na}, \mathrm{Mg}, \mathrm{Ca}$ ) sulfate minerals that have been documented to commonly form with Blödite and Thenardite were included in the calculation to account for the 
calcium in the sample. A final calculation was performed to account for the uncertainty in the hydration state of $\mathrm{Na}_{2} \mathrm{SO}_{4}$ which can occur with waters of hydration that vary from 0

(Thenardite) to 10 (Mirabilite). The hydration state is labile and responsive to environmental conditions of temperature and humidity. Since we dried the sample at $65 \mathrm{C}$, all of the $\mathrm{Na}_{2} \mathrm{SO}_{4}$ was present as Thenardite. The evaporite deposits under field conditions, however, would likely contain multiple hydration states. The last two columns in Table 3 provide the approximate range of mineral fractions for the key minerals in the evaporite, excluding the soil component and accounting for the possible range of Thenardite/Mirabilite hydration. The dominant mineral in the evaporite collected from the escarpment at Riverton was Blödite (approximately 66 to 76\% of the sample by weight). The minerals observed closely match the thermodynamic predictions from Geochemists Workbench for cases where site groundwater is evaporated to dryness. The correspondence of predicted and measured mineralogy suggest the possibility of mineral zonation within the Riverton subsurface, in which other evaporite mineral assemblages (e.g., with calcite and gypsum) may be present in areas of lower evaporation fraction.

Table 3. Mineralogical composition (XRD data and combined XRD-XRF data) of the Riverton WY evaporite scoping sample collected from the escarpment near well 789

\begin{tabular}{|c|c|c|c|c|c|c|}
\hline \multicolumn{2}{|c|}{ Sample mineral composition (mass fractions) } & & & \multirow{3}{*}{\multicolumn{3}{|c|}{$\begin{array}{c}\text { Best Estimates (XRD and XRF) } * * * \\
\text { fine powder }\end{array}$}} \\
\hline & & \multicolumn{2}{|c|}{ Raw Sample Results (XRD and XRF) } & & & \\
\hline & & total (normalized) & fine powder & & & \\
\hline & & & excl "soil" & \multicolumn{3}{|c|}{ excl "soil" } \\
\hline \multirow[t]{3}{*}{ soil contribution* } & \multirow{3}{*}{$\begin{array}{l}\text { quartz -- } \mathrm{SiO}_{2} \\
\mathrm{Al} 2 \mathrm{O} 3 \\
\mathrm{Fe} 2 \mathrm{O} 3\end{array}$} & 0.14 & -- & -- & -- & -- \\
\hline & & 0.02 & -- & -- & -- & -- \\
\hline & & 0.01 & -- & -- & -- & -- \\
\hline Halite & $\mathrm{NaCl}$ & 0.04 & 0.05 & 0.04 & to & 0.05 \\
\hline Blödite & $\mathrm{Na}_{2} \mathrm{Mg}\left(\mathrm{SO}_{4}\right)_{2}: 4 \mathrm{H}_{2} \mathrm{O}$ & 0.63 & 0.76 & 0.66 & to & 0.76 \\
\hline Thenardite / Mirabilite & $\mathrm{Na}_{2} \mathrm{SO}_{4} / \mathrm{Na}_{2} \mathrm{SO}_{4}: 10 \mathrm{H}_{2} \mathrm{O}$ & 0.10 & 0.12 & 0.24 & to & 0.12 \\
\hline Other evaporites** & & 0.06 & 0.07 & 0.06 & to & 0.07 \\
\hline
\end{tabular}

Assumptions:

shaded cells are assumed values

* quartz grains (SiO2), $\mathrm{Al} 2 \mathrm{O} 3$ and $\mathrm{Fe} 2 \mathrm{O} 3$ represent native soil; remaining fine powder material best represents evaporite mineral encrustation

** Other = minor unquantified XRD peaks (e.g., glauberite, various sodium magnesium calcium sulfates and chlorides and related evaporite minerals)

*** Best estimate ranges based on thenardite / mirabolite hydration end members and inclusion of assumed fraction of "Other"

The scoping sample collected at Riverton confirms the presence of secondary source minerals at the site and confirms the significant features of the conceptual model developed above. Based on the results, we anticipate additional areas within the site where these minerals may be accumulating in identifiable horizons. Incorporation of these concepts in future characterization would aid in refining and optimizing future Legacy Management actions. The results suggest that the portable XRF would provide rapid-high-quality data for $U$ and qualitative data for other useful major elements such as $\mathrm{S}, \mathrm{Cl}$ and $\mathrm{Ca}$. The application in the field (or close support location) can be performed using a variety of sampling options and configurations. In areas where sufficient materials can be collected, supplemental XRD and laboratory XRF would be useful. The XRD provides key information on the predominant minerals present. Laboratory XRF analysis extends the quantitative range down to Na. These supplemental tools applied to selected samples provide the basis to more fully document geochemical and thermodynamic controls, reduce technical uncertainty, and increase the robustness of any remedial response action proposed for the site. 


\section{Processes Controlling Molybdenum Behavior}

Under normal oxidizing environmental conditions molybdenum exists in the $\mathrm{Mo}(\mathrm{VI})$ state as the oxyanion $\mathrm{MoO}_{4}{ }^{-2}$. The $\mathrm{MoO}_{4}^{-2}$ ion does not sorb well at circumneutral $\mathrm{pH}$ and only forms soluble salts. Under sulfate reducing conditions $\mathrm{Mo}(\mathrm{VI})$ reduces to $\mathrm{Mo}(\mathrm{IV})$ and forms a low solubility sulfide $\left(\mathrm{MoS}_{2}\right)$. Therefore, in Riverton site groundwater molybdenum is expected to remain mobile unless it encounters a natural reducing zone. It is likely that some molybdenum would coprecipitate with evaporitic minerals and be mobilized when these minerals dissolve. Figure 31 shows Riverton site groundwater compositions relative to the speciation of molybdenum on an Eh-pH diagram and the stability of $\mathrm{MoS}_{2}$.

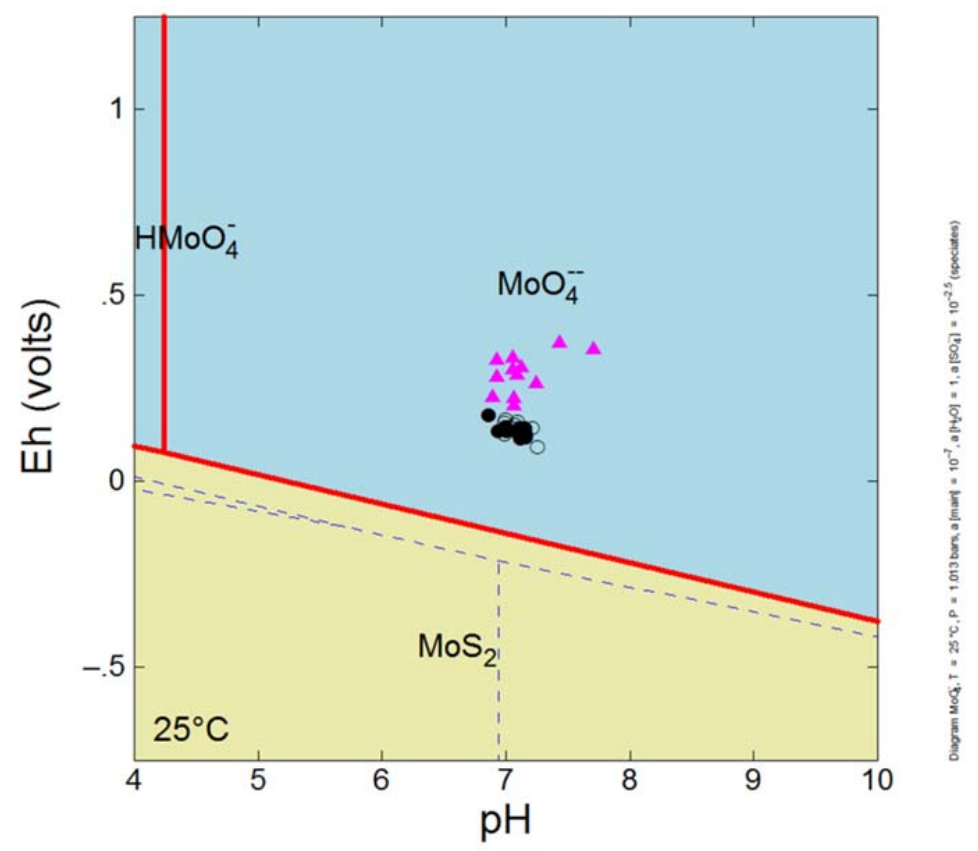

Figure 31: Eh-pH diagram of molybdenum speciation with sulfur present (triangles = well data; closed circles $=$ GeoProbe data transect T04, open circles $=$ GeoProbe data transect T08 )

\section{Processes Controlling Uranium Behavior}

Mineralization from capillary fringe processes or reduction is the most likely control on uranium in Riverton site groundwater. Figure 32 shows groundwater compositions relative to the stability of the minerals soddyite and carnotite. Samples from the heart of the plume are close to saturation with soddyite. The sample that lies on the solubility line is from well 0707 , obtained near the time of the 1991 flood. The starred sample is from well 0789, obtained in September of 2013. Degassing of $\mathrm{CO}_{2}$ or evaporation would bring the 0789 sample and those near it to saturation with soddyite. The samples are undersaturated with respect to carnotite, but could become saturated during $\mathrm{CO}_{2}$ degassing or evaporation. The groundwater is supersaturated with uranophane and uranium concentrations indicate it is not a controlling phase. Figure 33 shows the composition of Riverton site groundwater relative to uranium speciation on an Eh-pH diagram. The groundwater is undersaturated with respect to reduced uranium minerals, but some 
of the GeoProbe samples approach saturation. Again, loss of $\mathrm{CO}_{2}$ or evaporation could cause precipitation of uraninite or other reduced uranium phase in the more reduced groundwaters.

Overall, sorption of uranium onto sediments of the surficial aquifer will be limited. Speciation calculations suggest the dominant uranium species is the neutral $\mathrm{Ca}_{2} \mathrm{UO}_{2}\left(\mathrm{CO}_{3}\right)_{3(\mathrm{aq})}$ minimizing electrostatic attraction of uranium to mineral surfaces. This is consistent with the results of the batch, kinetic, and column studies presented in DOE (2013). As mentioned in Appendix A, Kd values fitted to uranium release curves from the column study appear to be in the range of 0.5$1.5 \mathrm{ml} / \mathrm{g}$. While overall uranium sorption may be low, it may vary spatially. Organic-rich sediments will sorb uranium more strongly and potentially reduce it from U(VI) to poorly soluble (U(IV).

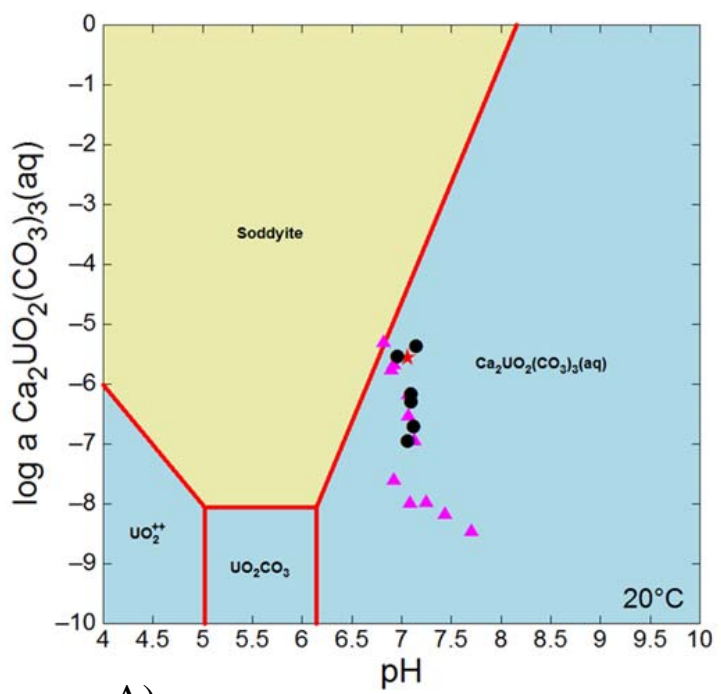

A)

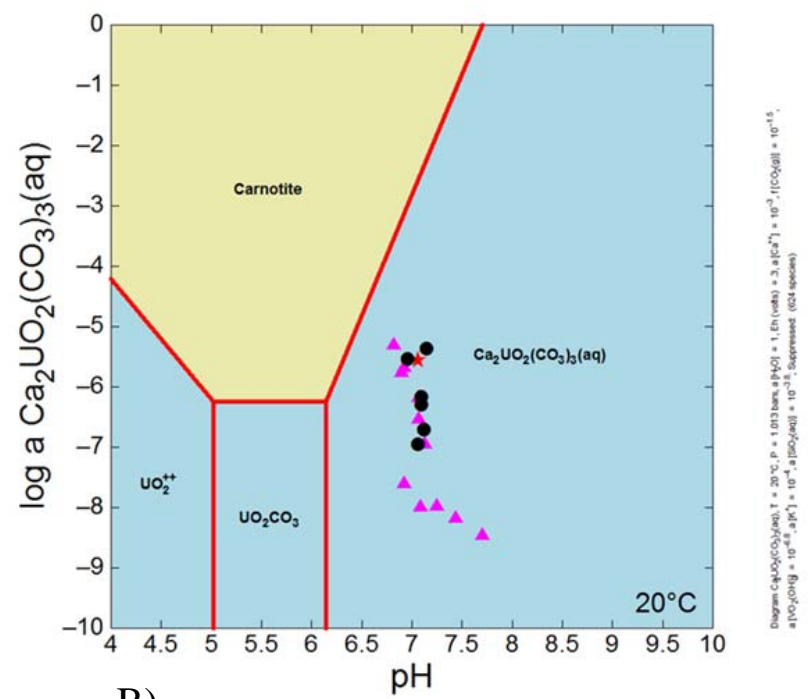

B)

Figure 32: Activity-activity diagrams showing stability of soddyite (A) and carnotite (B) relative to compositions of Riverton site groundwater; triangles = well data, circles = GeoProbe data, star = well 0789 . 


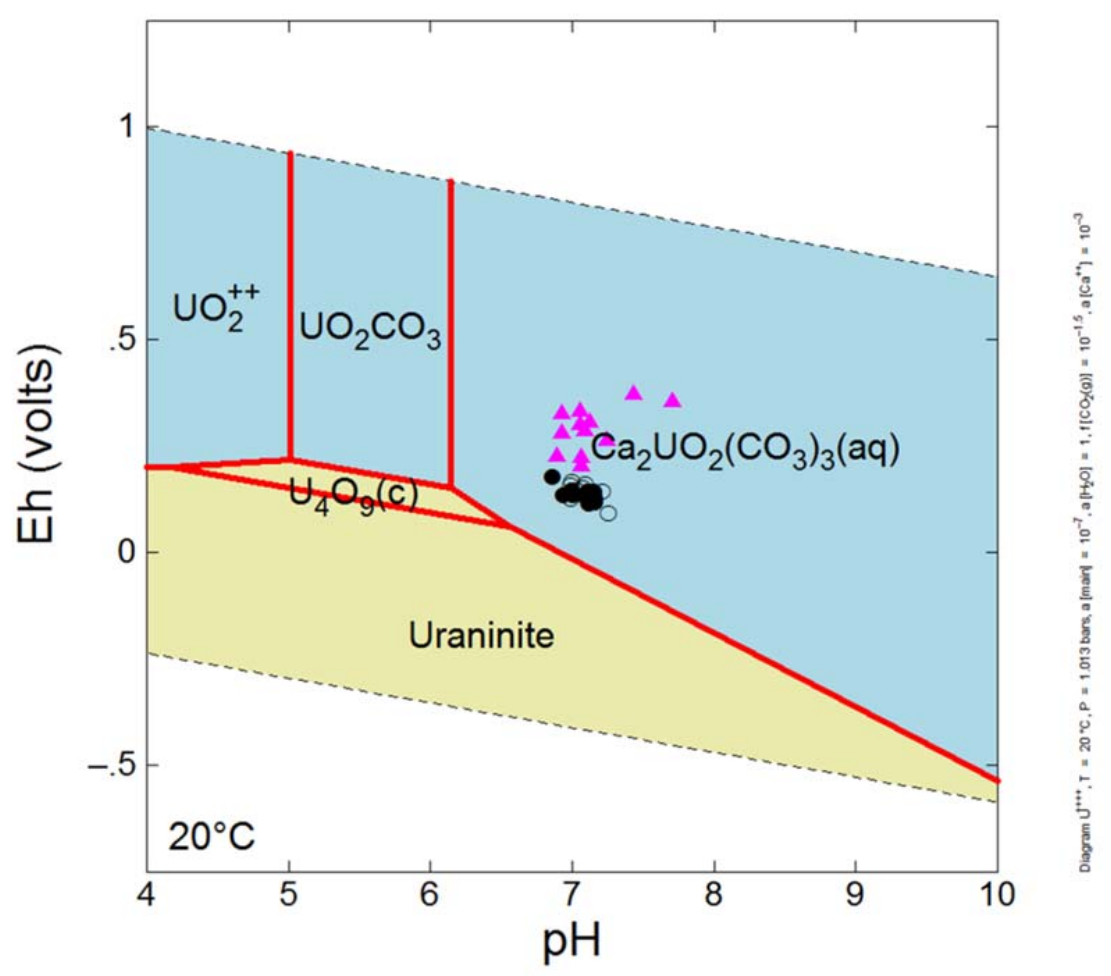

Figure 33: Eh-pH diagram showing speciation of uranium and stability of reduced uranium minerals relative to Riverton site groundwater compositions; triangles = well data, closed circles $=$ GeoProbe data transect T04, open circles = GeoProbe data transect T08.

\section{$\underline{\text { Seepage from the Sulfuric Acid Plant Effluent Ditch }}$}

Chemical trends in groundwater from the well (0784) and GeoProbe samples nearest the sulfuric acid plant effluent ditch suggest that sulfate is seeping into groundwater from the ditch. A ternary diagram of major cation composition of groundwater samples and surface water samples from the effluent ditch is shown in Figure 34. Water sampled from station 0749 at the upstream portion of the ditch near the plant has low magnesium concentrations compared to most groundwater samples from the Riverton site. The exception is water from well 0784 that has a composition similar to the ditch water. As water migrates down the ditch, magnesium concentration increases and the composition of the surface water sample at station 0822 is indistinguishable from groundwater. 


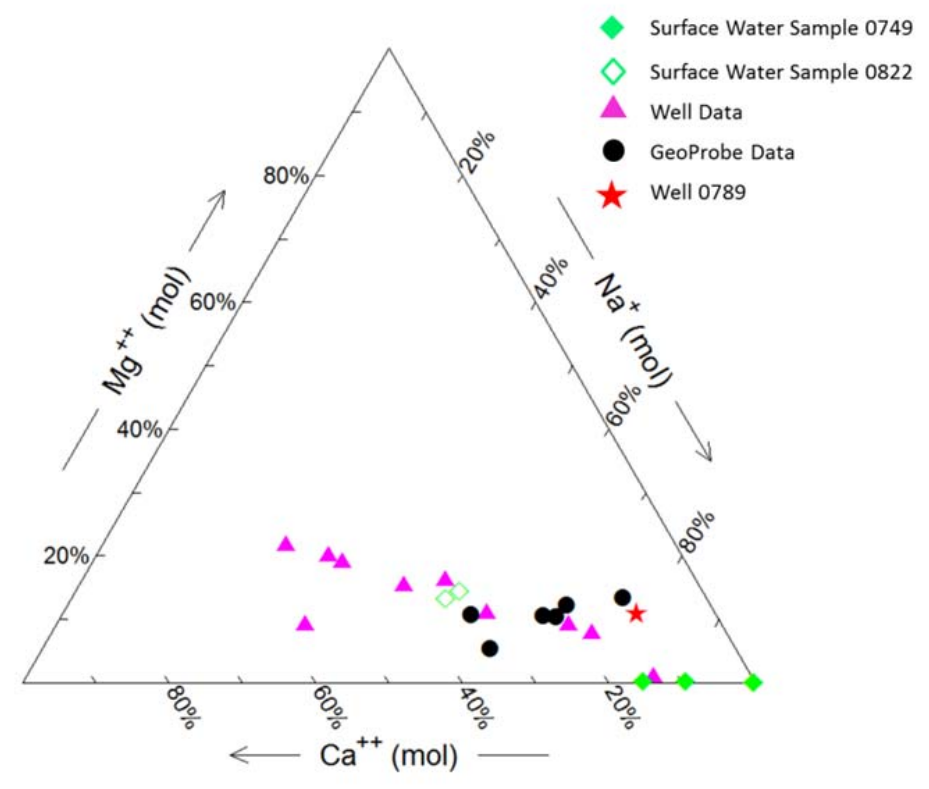

Figure 34: Ternary diagram of major cation composition of groundwater and water from the sulfuric acid plant ditch.

The GeoProbe groundwater samples provide the opportunity to test the extent to which water from the effluent ditch has seeped into groundwater. Figure 35 shows a polygon on the satellite image of the site that contains GeoProbe locations near and down gradient from the effluent ditch. Figure 36 shows the all of the GeoProbe groundwater data plotted as magnesium versus sulfate concentrations (blue diamonds) with the locations defined in Figure 35 plotted as red circles. All of the samples that show significant depletion in magnesium are near and down gradient of the effluent ditch. The 3 samples plotting along the main trend are T02-01, T03-01, and T03-02, located next to the ditch, but downstream of the plant discharge point. The data suggest that sulfate from the effluent ditch has reached as far as T03-08 and T03-09, approximately 1200 feet from the ditch. 


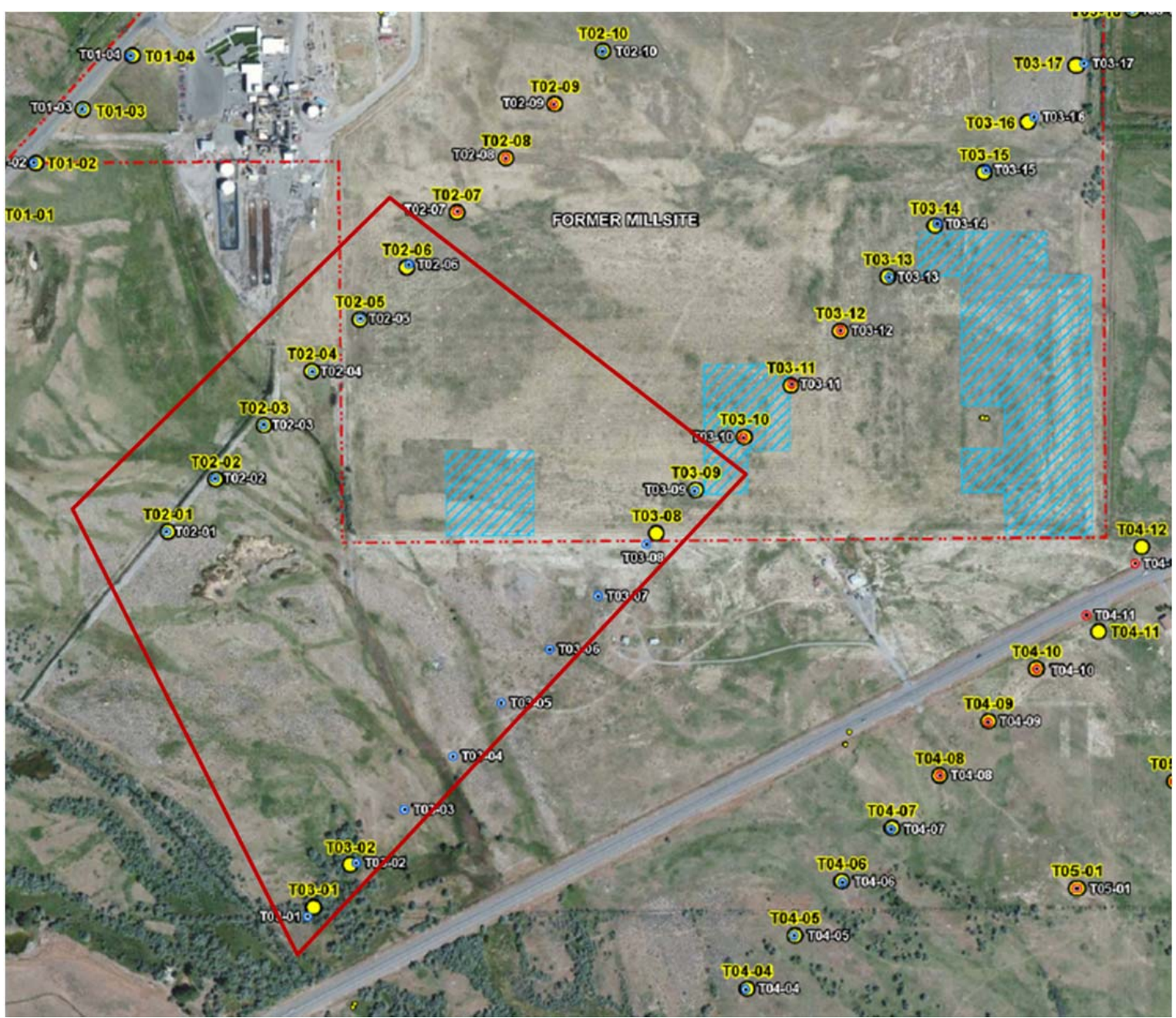

Figure 35: Locations of GeoProbe groundwater samples; those within the red polygon are the locations marked with red circles in Figure 36. 


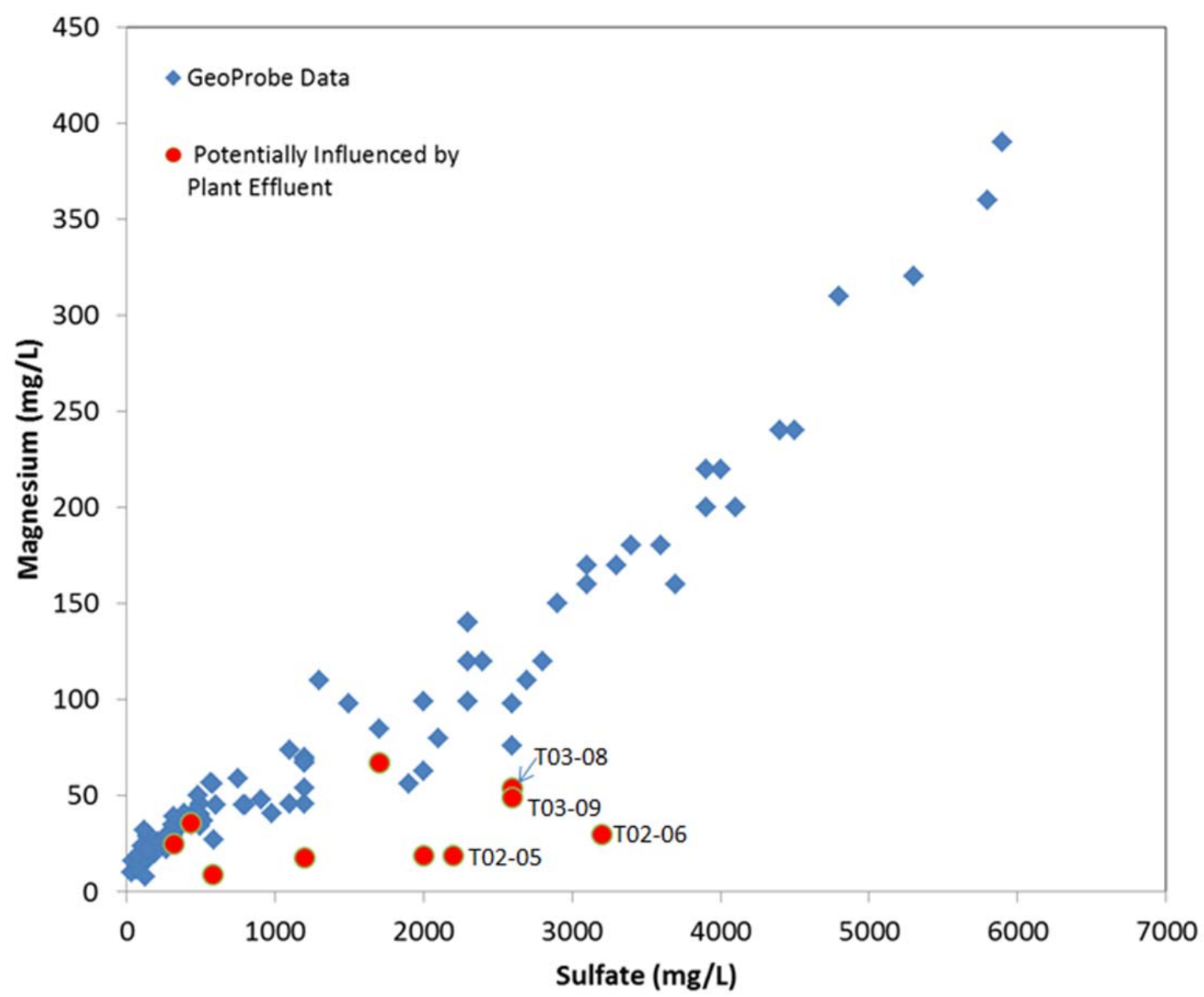

Figure 36: Magnesium versus sulfate concentrations in GeoProbe groundwater samples; red circles mark those near the effluent ditch (within the red polygon of Figure 35). 


\section{Interactions of the Frameworks}

Groundwater in the subsurface plume near the Riverton Processing Site discharges to the vadose zone and atmosphere, and to the Little Wind River and associated features such as oxbow lakes (Figure 37). The uppermost portion of the water table is subject to evaporation and evapotranspiration. This results in precipitation of minerals in the vadose zone near the water table and in surficial soils in areas where the water nears discharge areas and is close to the ground surface. As discussed above, these key features influence the distribution of contamination and the quantity, nature and location of precipitated minerals.

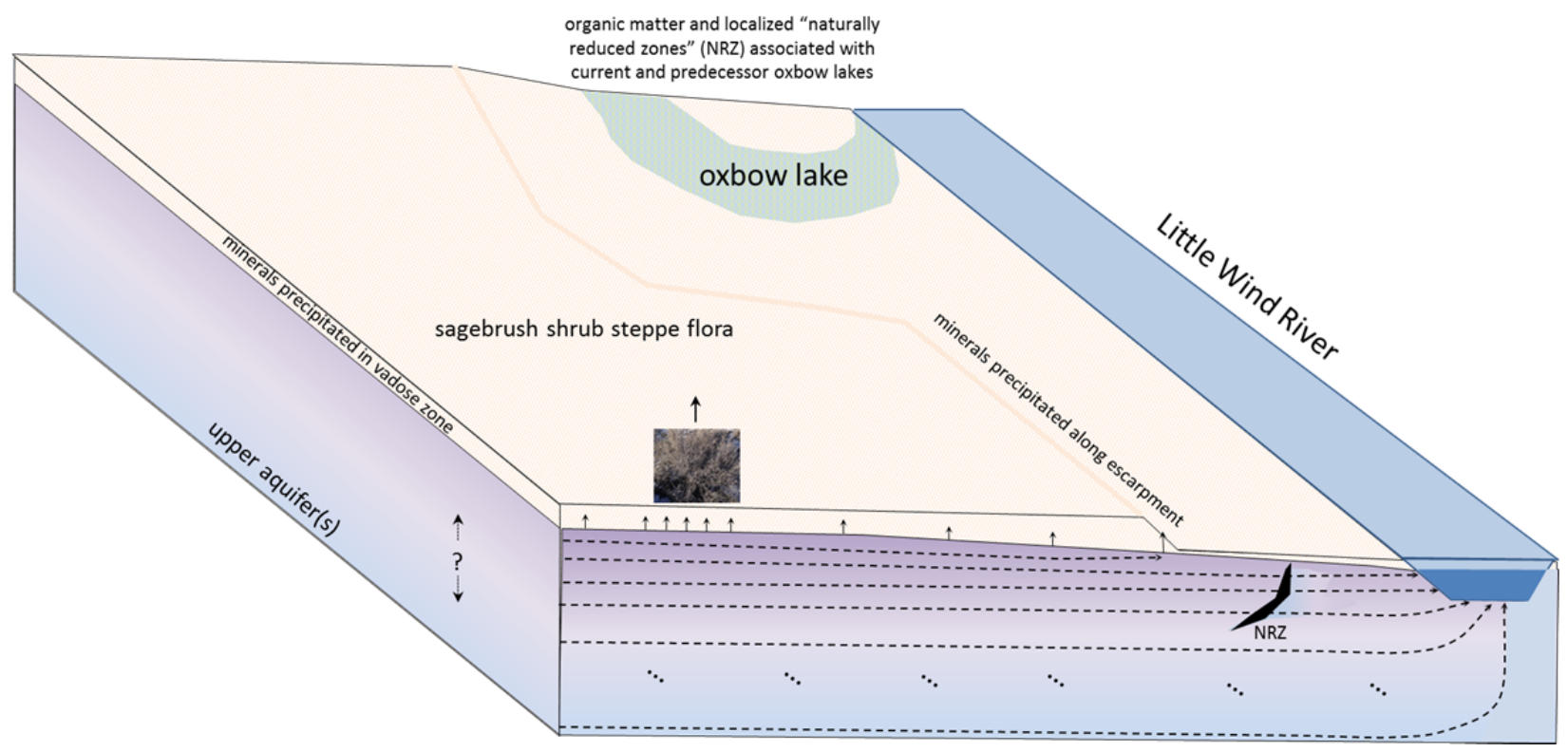

Figure 37. Simplified depiction detailing of some of the key features of the Riverton landscape in the mid-field plume and near the Little Wind River outcrop area

In summary, the available data from the site indicate:

- Physical removal of the tailings and associated soils and impacted materials significantly reduced contaminant discharges to groundwater and reduced contaminant concentrations in the near-field plume.

- In the mid-field and far-field areas, residual contaminants are present in the vadose zone as a result of a variety of factors (e.g., evaporation/evapotranspiration from the capillary fringe and water table, higher water levels during tailings disposal, and geochemical equilibria).

- Vadose zone contaminants are widely distributed above the plume and are expected to be present as solid phase minerals that can serve as "secondary sources" to the underlying groundwater. The minerals collected at the site are consistent with thermodynamic predictions.

- Water table fluctuations, irrigation, infiltration and flooding will episodically solubilize some of the vadose zone secondary source materials and release contaminants to the groundwater for continued down gradient migration. 
- Vertical contaminant stratification in the vadose zone and surficial aquifer will vary from location to location. Soil and water sampling strategies and monitoring well construction details will influence characterization and monitoring data.

- Water flows from the Wind River, beneath the Riverton Processing Site and through the plume toward the Little Wind River. This base flow pattern is influenced by seasonal irrigation and other anthropogenic activities, and by natural perturbations (e.g., flooding)

- Erosion and reworking of the sediments adjacent to the Little Wind River results in high heterogeneity and complex flow and geochemistry. Water flowing into oxbow lakes (or through areas where oxbow lakes were present in the past) will be exposed to localized geochemical conditions that favor chemical reduction (i.e., "naturally reduced zones”) and other attenuation processes. This attenuation is not sufficient to fully stabilize the plume or to reduce contaminant concentrations in the groundwater to target levels.

Figure 38 provides a graphical summary of the integrated conceptual model for the Riverton Processing Site formatted using a simplified spatial framework structure (i.e., near-field, midfield, far-field).

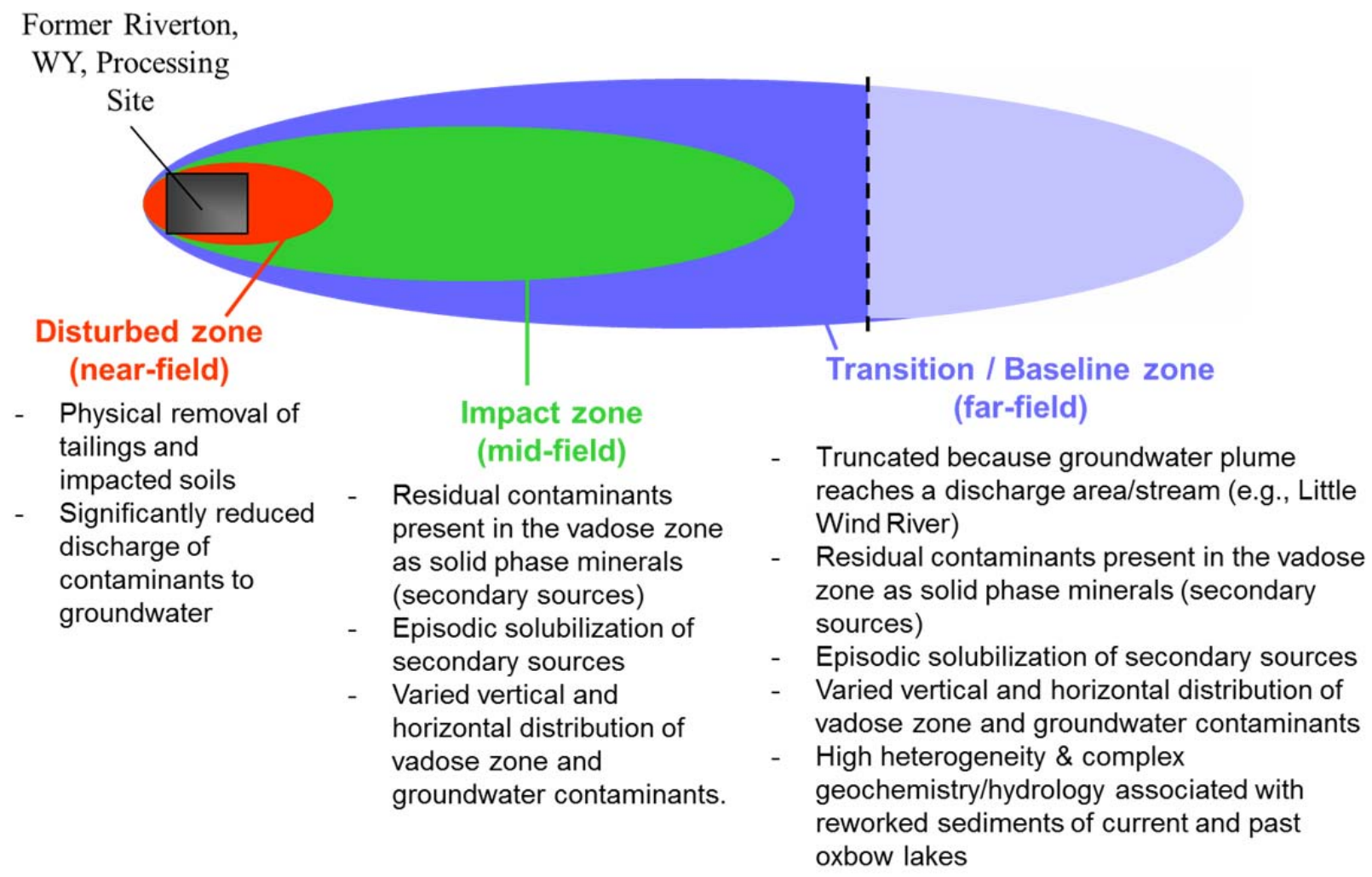

Figure 38. Site specific spatial framework annotated to describe integrated conceptual model 


\subsection{Results}

\section{Challenges and Opportunities Identified in the Framework Evaluation}

The technical framework evaluations identified a few key challenges and opportunities. The most notable challenge is the presence of secondary source solids in the vadose zone above the contaminated groundwater. This material would be expected to be present throughout the plume area and the dissolution of the secondary source will extend the time needed to reach target concentration goals in the groundwater. While concentrations of key constituents in the plume (e.g., U) are above drinking water limits (i.e., Maximum Contaminant Levels or MCLs) the overall levels of contaminants in the system are relatively low and pose minimal risks during the flushing period. For example, the secondary evaporite minerals collected at the site contained approximately $70 \mathrm{ppm} \mathrm{U} \mathrm{-} \mathrm{a} \mathrm{commonly} \mathrm{observed} \mathrm{concentration} \mathrm{level} \mathrm{for} \mathrm{this} \mathrm{type} \mathrm{of} \mathrm{mineral} \mathrm{in}$ the western U.S. (even in uncontaminated areas). Further, reworking of the area near the outcrop by the meandering Little Wind River would provide some level of contaminant attenuation because of the presence of naturally reduced zones. To assess the significance of some of the existing data and observations, additional characterization is warranted. Recommendations to LM for incorporation into future characterization activities and future management strategies for the groundwater near the Riverton Processing Site are presented below.

\section{Data Gaps and Recommended Characterization Activities to Resolve Uncertainties}

\section{$\underline{\text { Interpretation of Groundwater Data }}$}

A significant effort has and is being made to collect additional characterization data to develop and refine the site conceptual model in order to better understand contaminant behavior and migration. For example, routine groundwater sampling from the long term monitoring well network was supplemented with collection of groundwater at 103 borehole locations that were made during the 2012 characterization study. Samples were collected using a standardized procedure whereby after the Geoprobe rods were driven to 12 feet bgs or until rod refusal, 8 liters of water were purged from the rod. The 12-foot depth was used to approximate the average midpoint of the screened interval for the monitoring wells in the surficial aquifer that comprise the long-term monitoring network.

In the hydrologic framework presented earlier in the document, it is suggested that the plume migration is dominated by lateral movement away from the source, stratified vertically, and, in the surficial aquifer, is modified by hydrologic driving forces that will vary seasonally. During dry periods, the flow lines will discharge to both the Little Wind River and to the vadose zone and atmosphere (via evapotranspiration). Floods, irrigation and wet periods will result in infiltration and force flow lines through the middle and deeper portion of the surficial aquifer. Given this conceptual model, it is critical to evaluate sampling strategies in terms of seasonal variation, and care should be taken when combining different data types. Small differences in surface elevation may result in samples taken from different parts of the subsurface using a standard sampling depth (Figure 39). Above the water table, many of the identified processes will result in mineral deposits and horizons that develop at "fixed" distances up from the saturated zone (e.g. near the top of the capillary fringe). 


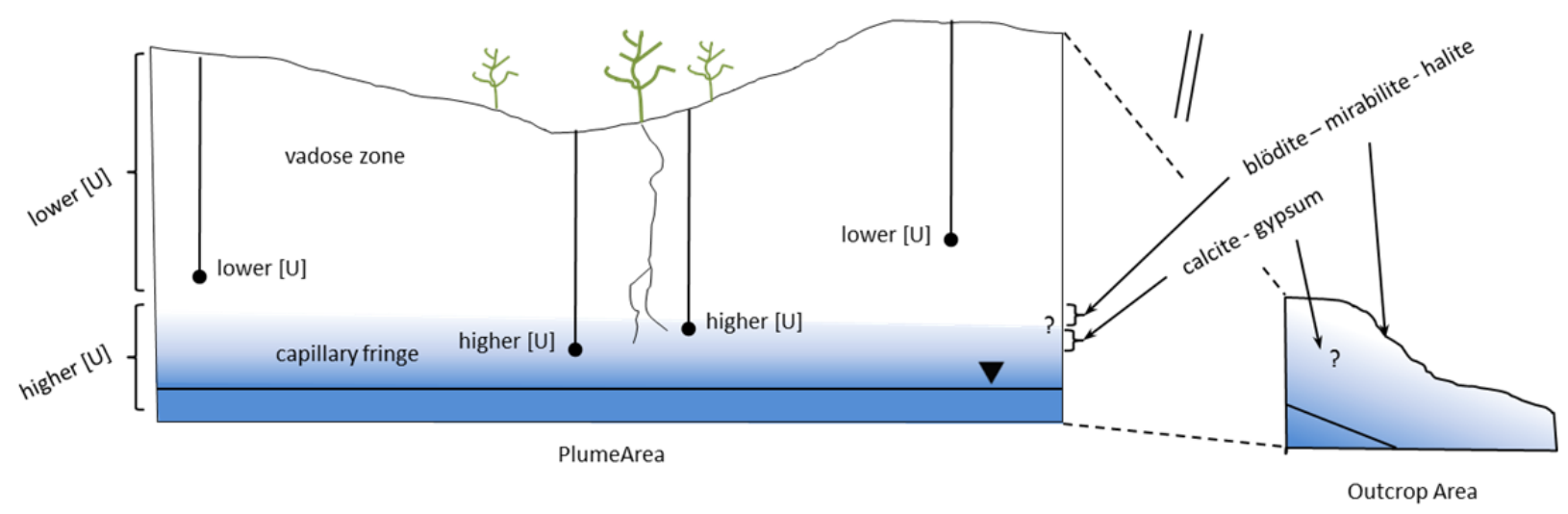

Figure 39. Key patterns of projected mineral and uranium, [U], accumulation. Note that the identified areas are generally associated with the position of the water table and outcrops rather than ground surface elevation

Similar to the vadose zone, vertical stratification is likely present in the groundwater plume. If water samples represent different elevations within the aquifer, measured concentrations would vary. Such variation can be misinterpreted as a horizontal pattern when data are plotted on a map. In both the vadose zone and groundwater cases, the conceptualization of the subsurface conditions would be improved by: a) using a sampling strategy based on nominal water table location (rather than ground surface) for characterization, and b) incorporating well construction and sampling depth information in the interpretation of groundwater plume geometry when mapping.

A second issue in interpretation of the groundwater concentration plume maps is created when maps with different sampling densities are presented together. The introduction of new control points, such as when groundwater well data is combined with Geoprobe groundwater sampling and contoured, may imply that new structures are present when in fact they may result only from the increase in control points. Ideally, plume mapping would be improved by honoring key aspects of the frameworks in the contouring of the data for all periods. This might require additional effort in the mapping process since it would be difficult to implement this recommendation if contouring is done by standard 'machine' kriging or similar algorithms that simply interpolate between data points. Alternatively, one could carefully annotate maps in which the control points are significantly different or have changed from previous (or following) time periods. These issues are important in presenting spatial distribution data to the public, many of whom do not understand the uncertainty in the data or typical plume behavior and who can easily misinterpret the differences in maps and changes in the environment rather than technical manifestation of the mapping process. 


\section{Field or Close Support Lab Analysis of Sediments}

The evaluation suggests that a portable XRF would provide rapid-high-quality data for $U$ and qualitative data for other useful major elements such as S, Cl and Ca in any future characterization studies. As noted above, the target depths and zones should be targeted to maximize the potential to confirm (or disprove) hypotheses related to where secondary minerals may be accumulating in the system. The application of XRF in the field (or close support location) can be performed using a variety of sampling options and configurations. In areas where sufficient materials can be collected, supplemental XRD and laboratory XRF would be useful. The XRD provides key information on the predominant minerals present. Laboratory $\mathrm{XRF}$ analysis extends the quantitative range down to Na to further quantify the amount of the different minerals.

\section{Geomorphology and Remote Sensing Data}

Stream systems represent a dynamic equilibrium between the sediment load carried by the stream and the energy available from stream flow to transport the sediment load. As a result, as river systems develop and mature through time, the characteristic geometries of meander belts develop naturally. A number of approaches have been developed to evaluate the morphology of river systems and to predict future behavior. As presented previously, the classic work by Rosgen $(1994,1996)$ allows characterization of streams based on channel morphology and form at a multiple scales. Subsequent studies have refined this approach and have developed strategies that can be used to relate channel dimensions, channel width, sediment load and/or discharge.

In addition, a number of remote sensing applications are available to interpret both satellite and multispectral data. Some of these techniques can be used to reveal geomorphological features such as past meanders and oxbow lakes. Other techniques provide quantitative estimates of ET that could be used to confirm and supplement the estimates derived from monitoring well and steam hydrographs.

A careful geomorphological analysis of the Little Wind River stream system south of the site could be used to provide important information that could be used to further refine the site conceptual model. Types of information that could be obtained through this study might include identification of fine-grained materials (point bars) within the meander system that would provide natural reducing zones, identification of erosional surfaces that might connect the surficial and semiconfined aquifers, former oxbow lakes that might have accumulated higher levels of organic matter and reduced minerals, and would allow for prediction of the temporal evolution of the stream system.

\section{Evaluation of Legacy Management Options}

There are a range of strategies for management of the legacy contamination in the groundwater and vadose zone near the Riverton Processing Site. These range from the current strategy, natural flushing, to intrusive remedies such as plume scale excavation of the vadose zone. Each option relates to the site specific conditions, issues and opportunities in a unique way. Further, 
each option has advantages and disadvantages that need to be weighed. Table 4 summarizes the results from a scoping evaluation of potential technologies and strategies for the Riverton groundwater. The technologies are presented in three major classes - contaminant removal technologies, contaminant stabilization technologies, and natural flushing. Major exemplars are assessed within each class. For instance, in the contaminant removal group, we include: plume scale excavation, small scale excavation, two variants of pump \& treat, and enhanced recovery (i.e., “solution mining”).

For each technology/strategy, we provide summary information in five topic areas (target media/zone, technology description, advantages, disadvantages, and risks) as well as a summary assessment. The summary assessment is structured to identify if the technology could be implemented (viable or not viable) followed by a team recommendation and/or detail. If a technology is not recommended, then the key issues that influenced that conclusion are provided. For example, in plume scale excavation the summary assessment is "viable but not recommended due to high costs and high risks and the potential for significant adverse collateral impacts." Similarly if a technology is conditionally recommended, then the associated conditions are provided. For example, in natural flushing the summary assessment is "viable and conditionally recommended -- requires additional study of timeframe, stakeholder communication, participation and acceptance.”

Note that the options in the table are not comprehensive - other technologies and strategies could be envisioned as well as combinations of technologies. The intent of the scoping evaluation is to triage the current site conditions and provide an initial rapid evaluation of options for consideration by LM as they finalize plans to address the Riverton groundwater plume. The summary recommendations for the various listed technologies and strategies (organized by recommendations) were:

Viable and Conditionally Recommended:

- Natural Flushing - need to address timeframe and stakeholder topics

- Structured Geochemical Zones - need to address pilot study, scale-up and cost topics

- Groundwater Pump \& Treat with Plume Scale Irrigation - need to consider uncertain timeframe of operation and high operation costs and energy use

Viable

- Enhanced Recovery - Potential for high costs and risks of adverse collateral impacts

- Bioremediation in Groundwater (Plume Scale) -- Potential for high costs and risks of adverse collateral impacts

Viable but Not Recommended

- Plume-Scale Excavation - high cost and risk

- Small Scale Excavation - ineffective (does not reduce timeframe relative to natural flushing)

- Groundwater Pump \& Treat (Extraction Wells) -- ineffective (does not reduce timeframe relative to natural flushing) 
- Groundwater Pump \& Treat (Recirculation Wells) -- ineffective (does not reduce timeframe relative to natural flushing)

- Permeable Reactive Barrier (Full Width) -- ineffective (does not reduce timeframe relative to natural flushing)

- Wall and Gate Treatment System -- ineffective (does not reduce timeframe relative to natural flushing)

Most of the technologies listed are standard and the conceptualization and implementation is done using standard engineering design and build approaches (e.g., natural flushing or groundwater pump \& treat with plume scale irrigation). In the conditionally recommended grouping, the structured geochemical zones concept is a notable technology approach that is worthy of additional description. This strategy tiers to recent regulatory guidance documents that focus on active treatments to transition sites toward natural attenuation (ITRC, 2008). For Riverton, we envisioned deploying a treatment reagent (electron acceptor) to promote the development of reduced zones. These would be distributed throughout the plume area and would supplement the naturally reduced zones already present at the site. In the case of Riverton with secondary source minerals in the lower vadose zone, we anticipate a two pronged reagent injection - "neat" vegetable oil in the vadose zone combined with areas of emulsified substrate below the water table. In the first part, neat oil injected in the vadose zone spreads laterally forming a thin layer in the capillary fringe and on the water table to react with the secondary source minerals in the lower vadose zone limiting future discharges into groundwater. In the second part, emulsified oil injected below the water table serves to stimulate formation of reduced zones within the active plume footprint to stabilize existing groundwater contamination. This general "structured geochemical zone" approach has been deployed at the T-Area of the DOE Savannah River Site in SC, and has been accepted by regulators for upcoming deployment at the DOE LM Mound Site in $\mathrm{OH}$. At Riverton, the geometry of the site and scale are different than the earlier deployments, so a pilot study would be a reasonable next step if an active remediation technology is deemed necessary. For example, the vadose oil deployment could be performed with closely spaced lance injection, with agricultural knife injection, or using a Geoprobe. The effort would require careful planning to maximize effectiveness while controlling deployment and reagent costs.

The unique history, geomorphology, hydrology and geochemistry at the Riverton Processing Site influence the current state of the groundwater plume and the projected flushing of the contaminants from the groundwater. The various technical frameworks applied to this site provide insights for consideration by DOE LM and the local stakeholders as future groundwater management plans are developed. 
Table 4. Example Technologies -- legacy management options related to contaminated groundwater near the Riverton Processing Site

\begin{tabular}{|c|c|c|c|c|c|c|}
\hline \multirow{2}{*}{\multicolumn{7}{|c|}{ Natural Flushing }} \\
\hline & Target Media / Zone & Description & Advantages & Disadvantages & Risks & Summary Assessment \\
\hline None & N/A & $\begin{array}{l}\text { Allow time for contaminants } \\
\text { to flush from the system } \\
\text { following the source removal } \\
\text { in 1988-1989 -- relies on } \\
\text { groundwater flow, } \\
\text { infiltration, flood events, } \\
\text { diffusion from fine grained } \\
\text { zones, and geochemical } \\
\text { processes to remove and } \\
\text { stabilize contamination to } \\
\text { meet target concentration } \\
\text { goals. }\end{array}$ & $\begin{array}{l}\text { Simple (requires only } \\
\text { monitoring) -- low costs }\end{array}$ & $\begin{array}{l}\text { Does not actively remove or stabilize } \\
\text { contaminants -- secondary source in the } \\
\text { vadose zone will extend the required } \\
\text { flushing period (current data suggest } \\
\text { that the timeframe to achieve target } \\
\text { concentrations is likely to be greater } \\
\text { than } 100 \text { years) }\end{array}$ & $\begin{array}{l}\text { Low worker risk -- low } \\
\text { environmental risk from } \\
\text { implementation -- low project risk } \\
\text {-- long timeframe to meet } \\
\text { concentration goals }\end{array}$ & $\begin{array}{l}\text { viable and conditionally recommended -- } \\
\text { requires additional study of timeframe -- } \\
\text { requires stakeholder communication, } \\
\text { participation and acceptance }\end{array}$ \\
\hline
\end{tabular}

\begin{tabular}{|c|c|c|c|c|c|c|}
\hline \multicolumn{2}{|c|}{ Contaminant Removal } & \multirow[b]{2}{*}{ Description } & \multirow[b]{2}{*}{ Advantages } & \multirow[b]{2}{*}{ Disadvantages } & \multirow[b]{2}{*}{ Risks } & \multirow[b]{2}{*}{ Summary Assessment } \\
\hline Technology & Target Media / Zone & & & & & \\
\hline \begin{tabular}{|l|} 
Plume-Scale \\
Excavation
\end{tabular} & $\begin{array}{l}\text { Soil -- contaminated } \\
\text { horizons in lower vadose } \\
\text { zone in the mid plume and } \\
\text { far-field areas }\end{array}$ & $\begin{array}{l}\text { Large scale excavation of } \\
\text { vadose zone (down to water } \\
\text { table) throughout plume } \\
\text { footprint }\end{array}$ & $\begin{array}{l}\text { Removes significant fraction of } \\
\text { secondary source }\end{array}$ & \begin{tabular}{|l|} 
Destroys entire downgradient \\
ecosystem (necessitating ecosystem \\
restoration)-- high potential for adverse \\
impacts to Little Wind River (e.g., \\
suspended solids) -- high \\
traffic/noise/energy use -- waste \\
generation -- high cost -- requires \\
removal of large volumes of \\
uncontaminated soil
\end{tabular} & \begin{tabular}{|l|} 
High worker risk -- high \\
environmental risk from \\
implementation -- high project \\
cost risk -- high transportation risk \\
-- potential reduction in \\
timeframe to meet concentration \\
goals compared to natural \\
flushing
\end{tabular} & $\begin{array}{l}\text { viable but not recommended -- high costs } \\
\text { and high risks -- significant adverse collateral } \\
\text { impacts }\end{array}$ \\
\hline \begin{tabular}{|l|} 
Small-Scale \\
Excavation
\end{tabular} & $\begin{array}{l}\text { Soil -- targeted "hot spot" } \\
\text { areas }\end{array}$ & \begin{tabular}{|l} 
Localized excavation of \\
vadose zone (down to water \\
table) in targeted areas
\end{tabular} & \begin{tabular}{|l|} 
Potential to reduce costs \\
versus plume-scale excavation \\
-- easily implementable
\end{tabular} & $\begin{array}{l}\text { Unlikely to impact plume -- current data } \\
\text { do not support the presence of hot } \\
\text { spots (or delineation of hot spots) to } \\
\text { target for cleanup -- significant } \\
\text { additional characterization would be } \\
\text { needed with no certainty that } \\
\text { appropriate target zones could be } \\
\text { identified }\end{array}$ & $\begin{array}{l}\text { Moderate worker risk -- moderate } \\
\text { environmental risk from } \\
\text { implementation -- high project } \\
\text { risk -- minimal reduction in } \\
\text { timeframe to meet concentration } \\
\text { goals compared to natural } \\
\text { flushing }\end{array}$ & $\begin{array}{l}\text { viable but not recommended -- ineffective -- } \\
\text { would not reduce overall plume } \\
\text { concentrations -- would not reduce } \\
\text { timeframe for remediation/flushing }\end{array}$ \\
\hline \begin{tabular}{|l|} 
Groundwater Pump- \\
and-Treat \\
(extraction wells)
\end{tabular} & Contaminated groundwater & \begin{tabular}{|l} 
Pump contaminated \\
groundwater to a standard \\
water treatment system and \\
discharge treated water to \\
river or reinject in \\
groundwater using wells
\end{tabular} & $\begin{array}{l}\text { Standard technology -- } \\
\text { interdicts and removes } \\
\text { contamination that is present } \\
\text { in the groundwater }\end{array}$ & \begin{tabular}{|l|} 
Does not address the secondary source \\
contamination in the vadose zone -- if \\
turned off, the timeframe for \\
remediation would not be significantly \\
different than natural flushing -- \\
requires significant o\&m and \\
continuous energy use
\end{tabular} & \begin{tabular}{|l|} 
Low worker risk --low \\
environmental risk from \\
implementation -- moderate \\
project risk -- minimal reduction \\
in timeframe to meet \\
concentration goals compared to \\
natural flushing
\end{tabular} & $\begin{array}{l}\text { viable but not recommended -- ineffective - } \\
\text { would not reduce timeframe for } \\
\text { remediation/flushing }\end{array}$ \\
\hline
\end{tabular}


Table 4. Example Technologies -- legacy management options related to contaminated groundwater near the Riverton Processing Site (cont)

\begin{tabular}{|c|c|c|c|c|c|c|}
\hline \multicolumn{2}{|c|}{ Contaminant Removal (cont) } & \multirow[b]{2}{*}{ Description } & \multirow[b]{2}{*}{ Advantages } & \multirow[b]{2}{*}{ Disadvantages } & \multirow[b]{2}{*}{ Risks } & \multirow[b]{2}{*}{ Summary Assessment } \\
\hline Technology & Target Media / Zone & & & & & \\
\hline $\begin{array}{l}\text { Groundwater Pump- } \\
\text { and-Treat } \\
\text { (recirculation wells) }\end{array}$ & Contaminated groundwater & $\begin{array}{l}\text { Pump contaminated } \\
\text { groundwater through } \\
\text { treatment material in a } \\
\text { recirculation well with two } \\
\text { screened intervals -- creates a } \\
\text { treatment cell in the aquifer } \\
\text { that can be predicted using } \\
\text { standard methods }\end{array}$ & $\begin{array}{l}\text { Available technology-- } \\
\text { interdicts and removes } \\
\text { contamination that is present } \\
\text { in the groundwater }\end{array}$ & $\begin{array}{l}\text { Smaller zone of influence per well than } \\
\text { standard pump and treat (requires more } \\
\text { wells -- in-well water treatment using } \\
\text { sorbents or ion exchange may require } \\
\text { larger diameter wells and/or frequent } \\
\text { replacement -- Does not address the } \\
\text { secondary source contamination in the } \\
\text { vadose zone -- if turned off, the } \\
\text { timeframe for remediation would not } \\
\text { be significantly different than natural } \\
\text { flushing -- requires significant o\&m and } \\
\text { continuous energy use }\end{array}$ & $\mid \begin{array}{l}\text { Low worker risk --low } \\
\text { environmental risk from } \\
\text { implementation -- moderate } \\
\text { project risk -- minimal reduction } \\
\text { in timeframe to meet } \\
\text { concentration goals compared to } \\
\text { natural flushing }\end{array}$ & $\begin{array}{l}\text { viable but not recommended -- ineffective- } \\
\text { would not reduce timeframe for } \\
\text { remediation/flushing }\end{array}$ \\
\hline $\begin{array}{l}\text { Groundwater Pump- } \\
\text { and-Treat (plume } \\
\text { scale irrigation) }\end{array}$ & Contaminated groundwater & \begin{tabular}{|l} 
Pump contaminated \\
groundwater to a standard \\
water treatment system and \\
distribute treated water over \\
plume area to enhance the \\
dissolution of secondary \\
source
\end{tabular} & $\begin{array}{l}\text { Available technology -- } \\
\text { interdicts and removes } \\
\text { contamination that is present } \\
\text { in the groundwater }\end{array}$ & $\begin{array}{l}\text { requires significant o\&m and } \\
\text { continuous energy use -- requires } \\
\text { significant large footprint infrastructure } \\
\text { - potential for impacts on ecosystem }\end{array}$ & \begin{tabular}{|l} 
Low worker risk --low \\
environmental risk from \\
implementation -- moderate \\
project risk -- minimal reduction \\
in timeframe to meet \\
concentration goals compared to \\
natural flushing
\end{tabular} & $\begin{array}{l}\text { viable and conditionally recommended -- } \\
\text { potentially effective -- uncertain timeframe } \\
\text { and potential for high operation costs and } \\
\text { high energy use }\end{array}$ \\
\hline $\begin{array}{l}\text { Enhanced Natural } \\
\text { Flushing }\end{array}$ & $\begin{array}{l}\text { Contaminated groundwater } \\
\text { and lower vadose zone soils }\end{array}$ & \begin{tabular}{|l|} 
Use broadly dispersed \\
amendments to change \\
geochemistry throughout the \\
contaminated soil and \\
groundwater zone (e.g., \\
increase alkalinity) or \\
diverted water infiltation to \\
enhance or increase the rate \\
of natural flushing -- \\
deployment could be \\
performed using standard \\
agricultural fertilization \\
practices or hydraulic \\
engineering.
\end{tabular} & \begin{tabular}{|l|} 
Depending on deployment \\
approach, treats solid phase \\
secondary sources as well as \\
contaminants dissolved in the \\
groundwater -- builds on \\
existing geochemical literature
\end{tabular} & $\begin{array}{l}\text { Mobilizes contaminants -- if not } \\
\text { combined with pump and treat this } \\
\text { approach would increase release of } \\
\text { contaminants to the surrounding } \\
\text { environment, uncertain performance } \\
\text { (may require long term pilot testing), } \\
\text { may require increased monitoring, may } \\
\text { require pump and treat or active } \\
\text { mineral collection at outcrop, moderate } \\
\text { cost }\end{array}$ & $\begin{array}{l}\text { Low worker risk -- moderate } \\
\text { environmental risk from } \\
\text { implementation -- } \\
\text { moderateproject risk -- limited } \\
\text { potential reduction in timeframe } \\
\text { to meet concentration goals } \\
\text { compared to natural flushing } \\
\end{array}$ & \begin{tabular}{|l|} 
viable but not recommended -- high \\
uncertainty and limited potential to reduce \\
timeframe for remediation/flushing
\end{tabular} \\
\hline Enhanced Recovery & $\begin{array}{l}\text { Contaminated groundwater } \\
\text { and lower vadose zone soils }\end{array}$ & $\begin{array}{l}\text { Flush groundwater and target } \\
\text { soil zone using lixiviants to } \\
\text { solubilize and enhance the } \\
\text { removal contaminants -- this } \\
\text { would be a modified version } \\
\text { of uranium solutions mining, } \\
\text { or in situ recovery, methods } \\
\text { that would use injection and } \\
\text { extraction wells }\end{array}$ & $\begin{array}{l}\text { Treats solid phase secondary } \\
\text { sources as well as } \\
\text { contaminants dissolved in the } \\
\text { groundwater -- builds on } \\
\text { existing in situ recovery mining } \\
\text { methods }\end{array}$ & $\begin{array}{l}\text { Injects and extracts large volumes of } \\
\text { liquid -- requires high level of control } \\
\text { on flow to assure that mobilized } \\
\text { contaminants are captured -- generates } \\
\text { large volumes of secondary waste -- } \\
\text { requires significant infrastructure -- } \\
\text { high cost }\end{array}$ & \begin{tabular}{|l|} 
Low worker risk -- moderate to \\
high environmental risk from \\
implementation -- moderate to \\
high project risk -- potential \\
reduction in timeframe to meet \\
concentration goals compared to \\
natural flushing
\end{tabular} & $\begin{array}{l}\text { viable -- potentially effective but significant } \\
\text { disadvantages and risks }\end{array}$ \\
\hline
\end{tabular}


Table 4. Example Technologies -- legacy management options related to contaminated groundwater near the Riverton Processing Site (cont)

\section{Contaminant Stabilization}

\begin{tabular}{|c|c|c|c|c|c|c|}
\hline Technology & Target Media / Zone & Description & Advantages & Disadvantages & Risks & Summary Assessment \\
\hline $\begin{array}{l}\text { Bioremediation in } \\
\text { Groundwater }\end{array}$ & $\begin{array}{l}\text { Contaminated groundwater } \\
\text { and possibly lower vadose } \\
\text { zone soils }\end{array}$ & \begin{tabular}{|l|} 
Traditional plume scale \\
bioremediation using injected \\
electron doner below the \\
water table
\end{tabular} & $\begin{array}{l}\text { Treats groundwater and } \\
\text { potentially treats solid phase } \\
\text { secondary sources near the } \\
\text { water table -- existing } \\
\text { technology }\end{array}$ & $\begin{array}{l}\text { Results in major large scale adverse } \\
\text { change in water chemistry (i.e., aerobic } \\
\text { to anaerobic) -- potential to adversely } \\
\text { impact subsurface and surface } \\
\text { ecosystem -- requires high level of } \\
\text { control on flow -- potential for } \\
\text { reoxidation over time --moderate cost }\end{array}$ & \begin{tabular}{|l|} 
Low worker risk -- moderate \\
environmental risk from \\
implementation -- moderate \\
project risk -- potential reduction \\
in timeframe to meet \\
concentration goals compared to \\
natural flushing
\end{tabular} & $\begin{array}{l}\text { viable -- potentially effective but significant } \\
\text { disadvantages and risks -- potential for } \\
\text { adverse collateral impacts from } \\
\text { implementation }\end{array}$ \\
\hline \begin{tabular}{|l|} 
Structured \\
Geochemical Zones
\end{tabular} & $\begin{array}{l}\text { Lower vadose zone soils } \\
\text { and contaminated } \\
\text { groundwater }\end{array}$ & \begin{tabular}{|l|} 
Inject electron donor (e.g., \\
vegetable oil into the lower \\
vadose zone to target \\
secondary source horizons \\
and zones of emulsified oils in \\
the groundwater plume) -- \\
the design basis would be to \\
expose the flowing \\
groundwater to new reduced \\
zones that would supplement \\
the naturally reduced zones \\
already present in the \\
Riverton subsurface \\
environment
\end{tabular} & $\begin{array}{l}\text { Treats solid phase secondary } \\
\text { sources near the water table } \\
\text { and the groundwater -- uses } \\
\text { existing technology (would } \\
\text { require a pilot study area) -- } \\
\text { significantly reduces adverse } \\
\text { collateral impacts compared to } \\
\text { traditional plume-wide } \\
\text { bioremediation because the } \\
\text { reduces zones are not } \\
\text { continuous and aerobic zones } \\
\text { are still present over much of } \\
\text { the plume area }\end{array}$ & $\begin{array}{l}\text { Potential to adversely impact portions } \\
\text { of the subsurface and surface } \\
\text { ecosystem -- requires high level of } \\
\text { control on flow -- potential for } \\
\text { reoxidation over time -- moderate cost }\end{array}$ & \begin{tabular}{|l|} 
Low worker risk -- low to \\
moderate environmental risk \\
from implementation -- moderate \\
project risk -- potential reduction \\
in timeframe to meet \\
concentration goals compared to \\
natural flushing
\end{tabular} & $\begin{array}{l}\text { viable and conditionally recommended -- } \\
\text { potentially effective-- would require pilot } \\
\text { study }\end{array}$ \\
\hline $\begin{array}{l}\text { Permeable reactive } \\
\text { barrier (full width) }\end{array}$ & Contaminated groundwater & \begin{tabular}{|l|} 
Install one or more trenches \\
that transect the plume -- \\
trenches into the surficial \\
aquifer and filled with \\
permable treatment media \\
(e.g., mulch, zero-valent-iron, \\
etc.)
\end{tabular} & $\begin{array}{l}\text { Available technology -- } \\
\text { interdicts and removes } \\
\text { contamination that is present } \\
\text { in the groundwater -- } \\
\text { physically limits footprint } \\
\text { ("length") of the plume -- } \\
\text { lower o\&m costs compared to } \\
\text { pump and treat }\end{array}$ & \begin{tabular}{|l|} 
Does not address the secondary source \\
contamination in the vadose zone -- \\
higher initial costs than pump \& treat -- \\
may require replacement or \\
rejuvination every 10 to 20 years -- the \\
overall timeframe for remediation \\
would not be significantly different \\
than natural flushing
\end{tabular} & \begin{tabular}{|l|} 
Low to moderate worker risk -- \\
low to moderate environmental \\
risk from implementation -- \\
moderate project risk -- minimal \\
reduction in timeframe to meet \\
concentration goals compared to \\
natural flushing
\end{tabular} & $\begin{array}{l}\text { viable but not recommended -- ineffective -- } \\
\text { would not reduce timeframe for } \\
\text { remediation/flushing }\end{array}$ \\
\hline \begin{tabular}{|l|} 
Wall-and-Gate \\
Permeable Reactive \\
Barrier or Treatment \\
Zone
\end{tabular} & Contaminated groundwater & $\begin{array}{l}\text { Install impermeable walls that } \\
\text { transect the plume with gates } \\
\text { (gaps) to funnel water to one } \\
\text { (or a few) small areas for in } \\
\text { situ treatment using reagents } \\
\text { such as phosphates, pH } \\
\text { adjustment, etc. }\end{array}$ & $\begin{array}{l}\text { Available technology -- } \\
\text { interdicts and removes } \\
\text { contamination that is present } \\
\text { in the groundwater -- } \\
\text { physically limits footprint } \\
\text { ("length") of the plume -- } \\
\text { lower o\&m costs compared to } \\
\text { pump and treat }\end{array}$ & \begin{tabular}{|l|} 
Does not address the secondary source \\
contamination in the vadose zone -- \\
higher initial costs than pump \& treat -- \\
requires periodic injection or treatment \\
actions (e.g., injection every 6 months \\
to 2 years) -- the overall timeframe for \\
remediation would not be significantly \\
different than natural flushing
\end{tabular} & \begin{tabular}{|l|} 
Low to moderate worker risk -- \\
low to moderate environmental \\
risk from implementation -- \\
moderate project risk -- minimal \\
reduction in timeframe to meet \\
concentration goals compared to \\
natural flushing -- would require \\
development of in situ treatment \\
reagents and pilot testing
\end{tabular} & $\begin{array}{l}\text { viable but not recommended -- ineffective -- } \\
\text { would not reduce timeframe for } \\
\text { remediation/flushing }\end{array}$ \\
\hline
\end{tabular}

Notes: o\&m = operations and maintenance 


\subsection{References}

Alonzo-Zarza, A.M. and V.P. Wright, 2010. Calcretes. Developments in Sedimentology, 61: 225-267.

Arakel, A.V. and D. McConchie, 1982. Classification and Genesis of Calcrete and Gypsite Lithofacies in Paleodrainage systems of Inland Australia and their relationship to Carnotite Mineralization, Journal of Sedimentary Petrology, 52:1149-1170.

Bargar, J.R., K.M. Campbell, J.E. Stubbs, E. Suvorova, K. Williams, J.S. Lezama-Pacheco, L.Y. Blue, J. Cerrato, R. Bernier-Latmani, D.E. Giammar, and P.E. Long, 2011, Speciation and dynamics of biologically reduced uranium (IV) in the Old Rifle Aquifer, paper presented at American Chemical Society Annual Meeting, Denver, CO.

Bethke, C.M., and S. Yeakel. 2012. The Geochemist's Workbench ${ }^{\circledR}($ geochemical modeling software), Release 8.0 Reference Manual, University of Illinois.

Bond, B. L., J. A. Jones, G. Moore, N. Phillips, D. Post, and J. J. McDonnell, 2002. The zone of vegetation influence on baseflow revealed by diel patterns of streamflow and vegetation water use in a headwater basin, Hydrol. Processes, 16, 1671- 1677.

Campbell, K.M., R.K. Kukkadapu, N.P. Qafoku, A.D. Peacock, E. Lesher, K.H. Williams, J.R. Bargar, M.J. Wilkins, L. Figueroa, J. Ranville, J.A. Davis, and P.E. Long, 2012, Geochemical, mineralogical and microbiological characteristics of sediment from a naturally reduced zone in a uranium contaminated aquifer, Applied Geochemistry, 27, 1499-1511.

Carlisle, D., 1980. Possible Variations on the Calcrete-Gypcrete Uranium Model. Report No. GJBX-53/80. U.S. Department of Energy Office of Scientific and Technical Information, Oak Ridge TN (www.osti.gov).

Carlisle, D., 1978. The Distribution of Calcretes and Gypcretes in Southwestern United States and their Uranium Favorability: Based on a Study of Deposits in Western Australia and Southwest Africa (Namibia). Report No. GJBX-29/78. U.S. Department of Energy Office of Scientific and Technical Information, Oak Ridge TN (www.osti.gov).

Clark, D.A., 1974, State-of-the-Art: Uranium Mining, Milling, and Refining Industry, EPA660/2-74-038, Robert S. Kerr Environmental Research Laboratory, Ada, OK.

Collinson, J.D., 1986, Alluvial Sediments, in Sedimentary Environments and Facies, ed. H.G. Reading, Blackwell Scientific Publications, Oxford.

Dahm, C. N., J. R. Cleverly, J. E. Allred-Coonrod, J. R. Thibault, D. E., McDonnell, and D. J. Gilroy (2002), Evapotranspiration at the land/water interface in a semi-arid drainage basin, Freshwater Biol., 47, 831-843. 
Denham, M. and K.M. Vangelas, 2009. Biogeochemical gradients as a framework for understanding waste site evolution, Remediation, 19: 5-17.

DOE, 2013. 2012 Enhanced Characterization and Monitoring Report Riverton, Wyoming, Processing Site, LMS/RVT/S09799, U.S. Department of Energy Office of Legacy Management, Grand Junction, CO, http://www.lm.doe.gov/riverton/Documents.aspx.

DOE, 1998, Final Site Observational Work Plan for the UMTRA Project Site at Riverton, Wyoming, U0013801, U.S. Department of Energy, Grand Junction, CO.

Dulohery, C. J., R. K. Kolka, and M. R. McKevlin, 2000. Effects of a willow overstory on planted seedlings in a bottomland restoration, Ecol. Eng., 15, S55-S66.

Farrington, P., G. D. Watson, G. A. Bartle, and E. A. N. Greenwood, 1990. Evaporation from dampland vegetation on a ground watermound, J. Hydrol., 115, 65- 75.

Fisk, H.N., 1947, Fine Grained Alluvial Deposits and Their Effects on Mississippi River Activity, Mississippi River Commission, Vicksburg, MS.

Gatewood, J. S., T. W. Robinson, B. R. Colby, J. D. Hem, and L. C. Halpenny, 1950. Use of water by bottom-land vegetation in lower Safford Valley, Arizona, U.S. Geol. Surv. Water Supply Pap., 1103.

Harvie, C.E., N, Moller, and J.H. Weare, 1984, The prediction of mineral solubilities in natural waters, the Na-K-Mg-Ca-H-Cl-SO4-OH-HCO3-CO3-CO2-H2O system to high ionic strengths at $25^{\circ} \mathrm{C}$. Geochimica et Cosmochimica Acta, 48, 723-751.

ITRC (Interstate Technology \& Regulatory Council). 2008. Enhanced Attenuation: Chlorinated Organics - Technical and Regulatory Guidance. EACO-1. Washington, D.C.: Interstate Technology \& Regulatory Council, Integrated DNAPL Site Strategy Team. www.itrcweb.org.

ITRC (Interstate Technology \& Regulatory Council). 2010. Use and Measurement of Mass Flux and Mass Discharge. MASSFLUX-1. Washington, D.C.: Interstate Technology \& Regulatory Council, Integrated DNAPL Site Strategy Team. www.itrcweb.org.

Jutras, P., J. Utting and J. McLeod, 2007. Link between long-lasting evaporitic basins and the development of thick and massive phreatic calcrete hardpans in the Mississippian Windsor and Percé groups of eastern Canada, Sedimentary Geology, 201:75-92.

Laczniak, R. J., G. A. DeMeo, S. R. Reiner, J. L. Smith, and W. E. Nylund, 1999. Estimates of ground-water discharge as determined from measurements of evapotranspiration, Ash Meadows Area, Nye County, Nevada, U.S. Geol. Surv. Water Resour. Invest. Rep., 99-4079.

Loheide, S. P., II, J. J. Butler Jr., and S. M. Gorelick (2005), Estimation of groundwater consumption by phreatophytes using diurnal water table fluctuations: A saturated-unsaturated flow assessment, Water Resour. Res., 41, W07030, doi:10.1029/2005WR003942. 
Looney, B.B, M.E. Denham, C.A. Eddy-Dilek and M.R. Millings 2013. Independent Technical Review of the Department of Energy Office of Legacy Management UMTRCA Groundwater Program, SRNL-STI-2013-00619, U.S. Department of Energy Office of Scientific and Technical Information, Oak Ridge TN. www.osti.gov.

Looney, B.B and R.W. Falta, eds., 2000. Vadose Zone Science and Technology Solutions. Battelle Press, Columbus OH. See for example pp 11-13 \& pp 50-57.

MACTEC (MACTEC Environmental Restoration Services, LLC), 1998. Final Site Observational Work Plan for the UMTRA Project Site near Tuba City, Arizona, MACGWTUB1.1, U.S. Department of Energy Office of Legacy Management, Grand Junction CO.

Mann A.W. and R.C. Horwitz, 1979. Groundwater calcrete deposits in Australia: some observations from Western Australia, Journal of the Geological Society of Australia, 26:293-303.

Markos, G., and K.J. Bush, 1982, Geochemical processes in uranium mill tailings and their relationship to contamination , in Management of Waste from Uranium Mining and Milling, IAEA, Vienna.

Narasimhan, T.N., R.M. Galbraith, A. White, A. Smith, H, Schmidt, B. Moed, and T.Tokunaga, 1982, Hydro-geochemical Studies of Uranium Mill-Tailing Piles at Riverton, Wyoming and Maybell, Colorado, LBL-14486, Lawrence Berkeley Laboratory, Berkeley, CA.

NAS, 1994, Alternatives for Groundwater Cleanup, National Academy Press, Washington, DC. Bethke, C.M.and S. Yeakel, 2012, The Geochemist’s Workbench ${ }^{\circledR}$ (geochemical modeling software), Release 9.0 Reference Manual, University of Illinois.

Peterson, J.A., D.P. Cox, and F. Gray, 1985. Mineral Resource Assessment of the Ajo and Laveville $1^{\circ}$ by $2^{\circ}$ Quadrangles, Arizona. U.S. Geological Survey, Reston VA, supplement to map MF-1834-B.

Purvis, K. and V. P. Wright, 1991. Calcretes related to phreatophytic vegetation from the Middle Triassic Otter Sandstone of South West England, Sedimentology, 38:539-551.

Qafoku, N.P., R.K. Kukkadapu, J.P. McKinley, B.W. Arey, S.D. Kelly, C. Wang, C.T. Resch, and P.E. Long, 2009, Uranium in framboidal pyrite from a naturally reduced alluvial sediment, Environmental Science \& Technology, 43, 8528-8534.

Remson, I., and J. R. Randolph (1958), Root growth near tensiometer cups as a cause of diurnal fluctuations of readings, Soil Sci., 85, 167-171.

Rosgen, D.L., 1994. A classification of natural rivers, Cantena, 22:169-199.

Rosgen, D.L., 1996. Applied River Morphology. Wildland Hydrology. Pagosa Spring, CO. 
Scott, R. L., C. Watts, J. Garatuza, E. Edwards, D. C. Goodrich, and D. Williams, 2002. Measuring the distribution of surface energy and water fluxes in a riparian mesquite savannahtype ecosystem, paper presented at 2nd Annual Meeting, Semi-Arid Hydrol. and Riparian Areas (SAHARA), Tucson, Ariz.

Seyedabbasi, M.A., C.J. Newell, D.T. Adamson, and T.C. Sale, 2012, Relative Contribution of DNAPL dissolution and matrix diffusion to the long-term persistence of chlorinated solvent source zones, Journal of Contaminant Hydrology, 134-135, 69-81.

Spotl, C. and V.P. Wright, 1992. Groundwater dolocretes from the Upper Triassic of the Paris Basin, France: a case study of an arid, continental diagenetic facies, Sedimentology, 39:1119-1 136.

Tokunaga, T.K., Y. Kim, and J. Wan, 2009. Potential remediation approach for uraniumcontaminated groundwaters through potassium uranyl vanadate precipitation, Environmental Science \& Technology, 43: 5467-54-71.

Tromble, J. M., 1977. Water requirements for mesquite (Prosopis juliflora), J. Hydrol., 34, 171179.

Troxell, H. C.,1936. The diurnal fluctuation in the ground-water and flow of the Santa Ana river and its meaning, Eos Trans. AGU, 17(4), 496-504.

Tyler, S.W., J.F. Munoz, and W.W. Wood, 2006. The Response of Playa and Sabkha Hydraulics and Mineralogy to Climate Forcing, Ground Water, 44:329-338.

USGS, 2014. Current Conditions for Wyoming: Streamflow. U.S. Geological Survey Water Resources Division, National Water Information System: Web Interface, accessed 04/08/2014, http://waterdata.usgs.gov/WY/nwis/current/?type=flow .

Wan, J., W. Dong, T.K. Tokunaga, 2011. Method to attenuate U(VI) mobility in acidic waste plumes using humic acids, Environmental Science \& Technology, 45: 2331-2337

White, W. N., 1932. A method of estimating ground-water supplies based on discharge by plants and evaporation from soil: Results of investigations in Escalante Valley, Utah, U.S. Geol. Surv. Water Supply Pap., 659-A.

Zachara, J.M., P.E. Long, J. Bargar, J.A. Davis, P. Fox, J.K. Fredrickson, M.D. Freshley, A.E. Konopka, C. Liu, J.P. McKinley, M.L. Rockhold, K.H. Williams, and S.B. Yabusaki, 2013, Persistence of uranium groundwater plumes: Contrasting mechanisms at two DOE sites in the groundwater-river interaction zone, Journal of Contaminant Hydrology, 147, 45-72. 
Appendix A

Independent Technical Review Team STATEMENT OF WORK 


\section{Scope: SRNL support on Riverton UMTRA site}

The DOE-LM Site Manager for the Riverton, Wyoming UMTRA site requests technical evaluations to be performed by key personnel from DOE's Savannah River National Laboratory (SRNL). Verifying recent analyses, which indicate the natural flushing compliance strategy may not be achievable, are needed. Plans are being developed for additional field, lab, and modeling work to increase understanding of controls, pathways, and fluxes affecting contaminant transport and potential ecological receptors. Routine monitoring of dissolved contaminants in groundwater is expanding to a watershed scale involving rivers, lakes, unsaturated zone, surficial aquifer and sediments. The need for enhanced characterization is the result of a flood event which caused groundwater constituents to unexpectedly increase in concentration.

The site is located on the Wind River Indian Reservation enhancing the visibility and interest among numerous stakeholders including elected officials and members of the Northern Arapaho and Eastern Shoshone tribes. DOE is committed to providing credible explanations of technical issues to the non-technical public to build confidence and trust in correcting impairment to the environment and community resources.

As stated in the most recent report (2012 Enhanced Characterization and Monitoring Report Riverton, Wyoming, Processing Site LMS/RVT/ S09799 J une 2013), "Although DOE obtained a better understanding of the site conceptual model, contaminant distributions, and properties of the unsaturated zone of the surficial aquifer at the Riverton site in 2012, additional work is needed to further define the conceptual model, to better understand geochemical processes that control contaminant fate and transport, to identify additional sources of uranium that are liberated during flood events, and to understand why uranium concentrations decline relatively quickly after flood events. This additional information will assist in making decisions for a pathforward compliance strategy. Recommendations for potential future work are listed in Table 16."

Current questions include:

- What additional data and models are needed to locate and explain contaminant (uranium, molybdenum, manganese, and sulfate) sources and sinks?

- Should we develop a statistical basis for the sampling grid and data analyses (such as using a Bayesian approach and/or visual sampling plan)?

- Is the three-aquifer groundwater system adequately monitored for flow and water quality including recharge and discharge areas?

- What tests can be performed to discern between physical (diffusive), hydrologic (advective) and geochemical controls (e.g. sorption, redox) on contaminant migration?

- What codes and models should be selected/created and would transient st0chastic modeling be useful to provide probability estimates for natural attenuation (such as we have a $75 \%$ likelihood of flushing within 100 years)?

Specific FY14 tasks include: 1) provide review comments on the June 2013 report, 2) join a field trip to the site currently planned for October or November, and 3) contribute to the characterization plan due in February 2014 with field work to restart in the summer of 2014. 


\title{
Appendix B.
}

\section{Independent Technical Review Team Team Member Biographies}

\author{
Miles E. Denham, Savannah River National Laboratory \\ 773-42A, Aiken SC 29808 \\ 803-725-5521 \\ miles.denham@srnl.doe.gov
}

Miles Denham is a research geochemist at the Savannah River National Laboratory (SRNL) studying metal and radionuclide contamination in soil and groundwater. He began his career at SRNL in 1992 following receipt of his Ph.D. from Texas A\&M University. His research focuses on innovative practical methods of remediating metal and radionuclide contaminated sites, as well as developing characterization techniques that facilitate remediation. Specific interests include environmental mineralogy and geochemical heterogeneity in the subsurface.

Dr. Denham has applied his expertise as lead geochemist on successful site closures across the Savannah River Site. In addition, he has served on numerous teams that have provided technical assistance on characterization and remediation at different sites across the Department of Energy (DOE) complex. Currently, Dr. Denham is the technical lead on a national applied research effort on developing the use of natural attenuation and enhanced attenuation remedies for metal and radionuclide contamination of soils and groundwater. The DOE Office of Environmental Management that is funding this effort has also recently funded Dr. Denham to study enhanced attenuation remedies in Chernobyl Exclusion Zone soils. Dr. Denham is author on numerous publications and in 2009 received a research award from the American Association of Petroleum Geologists Division of Environmental Geosciences for his contributions to the field of environmental geosciences.

\section{Carol A. Eddy-Dilek}

773-42A, Aiken SC 29808

803-761-1826

carol.eddy-dilek@srnl.doe.gov

Carol Eddy-Dilek is a Senior Technical Advisor at the Department of Energy Savannah River National Laboratory. For the past 25 years, she worked on a variety of programs focused on development and deployment of innovative approaches and tools for environmental characterization and remediation, specifically, the design and optimization of phased characterization strategies that can be applied to complex and challenging environments. Her efforts resulted in the successful development or deployment of over fifty innovative methods for subsurface access and characterization that have been successfully applied within the DOE complex.

Since 2002, she has been the technical lead for the Department of Energy's Technical Assistance program at the Savannah River National Laboratory that provides technical support to the DOE complex. Since 2006, she has organized more than 25 teams that have visited eleven DOE sites and made recommendations yielding an estimated cost savings of \$100M. From 2002 to 2006, she coordinated technical assistance activities for the DOE Ohio Closure Sites (Fernald, 
Ashtabula and Mound) which provided technical experts to address challenging environmental issues that were encountered during the expedited closure process.

From 1996 to 2001 she initiated and managed a program for the DOE complex program that developed, tested and evaluated more than twenty innovative characterization technologies for the cone penetrometer that resulted in widespread acceptance of direct push methods for site characterization. The program began at SRS and eventually resulted in successful application of innovative approaches and technologies at many federal and commercial sites. From 1999 to 2001 she was the DOE lead for the Interagency DNAPL consortium program at the Cape Canaveral, a joint EPA-DoD-DOE program for evaluation of DNAPL characterization and remediation technologies.

\section{Brian B. Looney, Savannah River National Laboratory}

773-42A, Aiken SC 29808

803-725-3692

Brian02.looney@srnl.doe.gov

Dr. Brian Looney is a Senior Advisory Scientist with the Savannah River National Laboratory and an adjunct professor in the Earth and Environmental Science Department at Clemson University. Brian earned a B.S. in Environmental Science from Texas Christian University and a Ph.D. in Environmental Engineering from the University of Minnesota. For the past 29 years, he has developed environmental characterization and remediation technologies for organic contaminants, metals and radionuclides. His work focuses on matching characterization and cleanup technologies to the specific conditions and needs at each site and developing technical approaches for that matching process. Dr. Looney coordinates development and deployment of innovative environmental characterization and clean-up methods at the Savannah River Site, and serves as a technical advisor supporting the DOE Environmental Management Program. He has received numerous awards and has authored and edited many publications including the recent book, Vadose Zone Science and Technology Solutions. Dr. Looney has ten patents for innovations in environmental technology. 


\section{Appendix C: Review of the "2012 Enhanced Characterization and Monitoring Report Riverton, Wyoming, Processing Site (LMS/RVT/S09799)”}

The report demonstrates the ongoing diligent and thorough effort to characterize and understand contaminant behavior at the Riverton Processing Site. The groundwater, surface water, and soil data collected are critical to improving the conceptual model of the site. The adjustments to the site conceptual model presented in the report are important; additional characterization is warranted to learn more about the nature of the secondary source of contaminants in the unsaturated zone. The following are a few comments on the 2012 Enhanced Characterization and Monitoring Report Riverton, Wyoming, Processing Site.

Page 32 ๆ 2: Is the elevated radium in the Chemtrade ditch in the form of sulfate minerals? If so, are there implications for transport of radium in groundwater?

Page 32 93: "data indicate the oxbow lake is fed by the discharge of contaminated groundwater" seems to contradict the earlier explanation for downward gradients in the surficial aquifer. The explanation was that surface water bodies are "recharging" the aquifer resulting in localized higher hydraulic heads in the surface water bodies.

Page 50: (Table 6) There doesn't seem to be much point to including Table 6. The assumption used to calculate the Kd values is tenuous and the high calculated values are inconsistent with known uranium behavior at the site. Caution should be exercised in reporting Kd values because they are so easy to misuse. For example, the values reported in Table 6 could be used to argue that uranium will never flush out of the system. Worse yet, and the TAT has seen such abuse, they could be used to argue that given the concentrations in groundwater there must be an enormous uranium source term in the aquifer.

Page 51: (Figure 32) It would be interesting to examine the Geoprobe soil data in terms of elevation of the samples. Variations in ground surface topography would result in a variety of elevations being sampled when sampling is done at constant depth (i.e., two samples taken from the same depth may be from different elevations). If there is a particular horizon in which uranium is accumulated this might help explain the apparent spatial heterogeneity in how uranium is distributed between the shallow and deeper samples.

Page 53: $\quad$ Again, there seems to be an overemphasis on deriving Kd values from studies that were not designed for this purpose. The column studies were designed to test how fast uranium flushes from site sediments and are effective for that purpose. Uranium flushes rapidly from most samples within 20 pore volumes and then concentrations decrease linearly with increasing pore volumes (Figure 3 Data Summary Report). At the risk of continuing to overemphasize Kd values, the release curves shown in the data summary report do not seem consistent with the Kd vs. Pore Volume curves in Figure 33. Was a constant soil concentration was used to calculate the Kd values. If so, a linear increase in $\mathrm{Kd}$ with increasing pore volumes would be calculated given the linear behavior of the release curves after about 20 pore volumes. The concentrations of uranium in the column eluent decreases with increased flushing of pore volumes, leading to increasing $\mathrm{Kd}$ values, if a constant soil concentration was used in the calculation. If some idea of 
Kd were required it would be better to fit modeled Kd curves to the release curves in Figure 3 of the data summary report. The figure below shows Figure 3 (up to 40 pore volumes) compared to a modeled Kd curve based on an initial soil concentration of $1.52 \mathrm{ug} / \mathrm{g}$ and a fractional porosity of 0.3 . Similar modeled curves could be fit to the release curves beyond the first few pore volumes. Uranium behavior in the first few pore volumes of most of the curves is more complicated than a simple Kd type behavior.
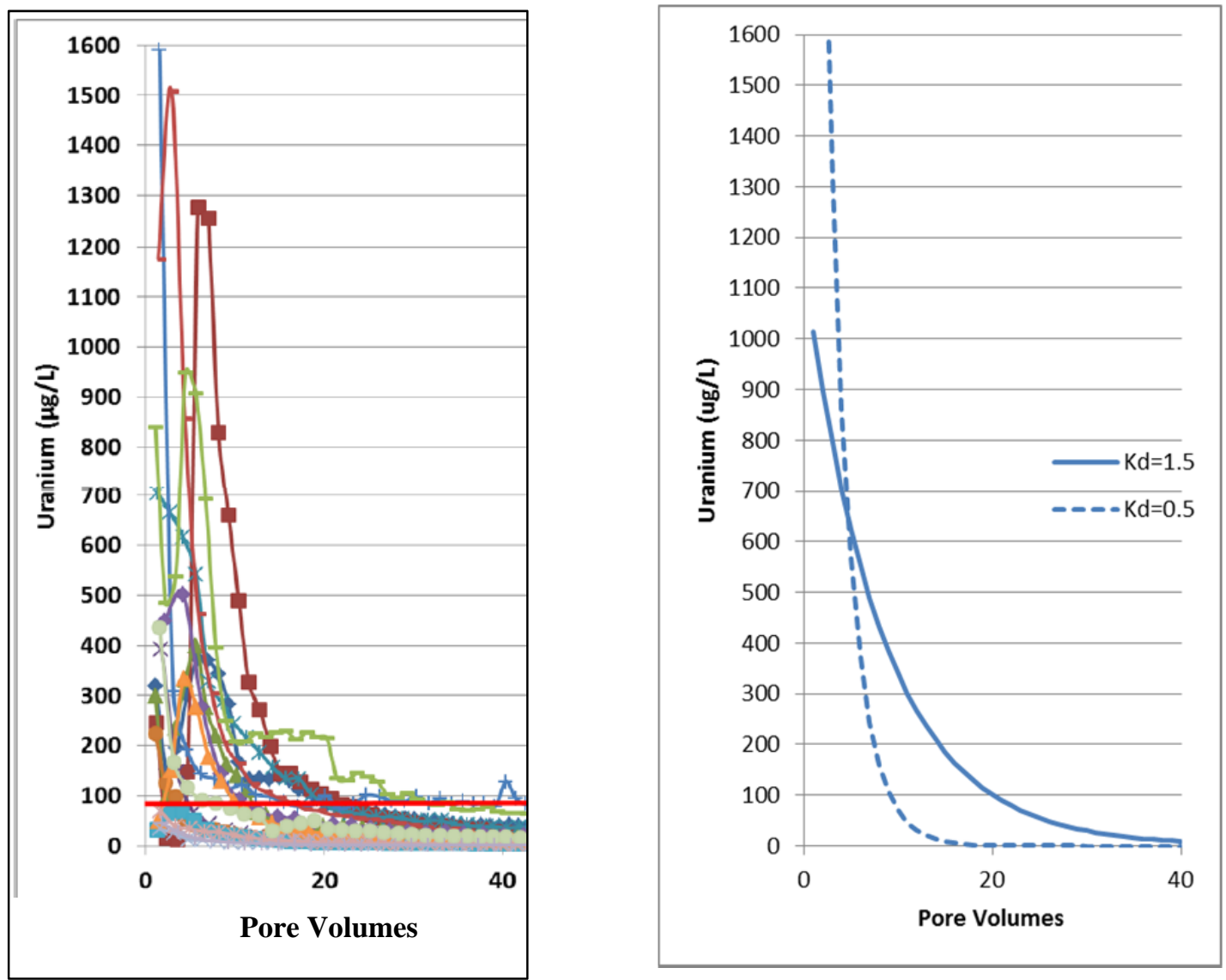

Page 62: (Figure 35) The apparent spatial distribution of uranium in the groundwater plume shown in Figure 35 may be biased by sampling at relatively constant depths. When sampling at constant depth, surface topography results in samples taken at different elevations. If there is any vertical stratification in the plume, then variations in uranium concentration at depth may be misinterpreted as the horizontal distribution of uranium when data are plotted on a map.

Page 73: (Table 9) The bulk density of $2.51 \mathrm{~g} / \mathrm{cm}^{3}$ seems more like a mineral density than a bulk density of sediment (i.e., a sample with no porosity).

Figures 9, 10, 13, 14, 37, 38, 39, 40: The way the data are contoured in figures showing distribution of constituents implies greater knowledge of the plume distribution than the data can provide. Presumably these were "machine" contoured using kriging or another algorithm to interpolate between data points. One problem with this method is that the resulting plume maps imply certainty, there is no way to indicate suspected but unconfirmed contours. There is also no way to incorporate 
known plume behavior. For example, in Figure 14 we can be sure that the plume does not stop on a straight line between wells 0788 and 0789. Known plume behavior suggests it likely continues until it crops out into the Little Wind River. This is important in presenting spatial distribution data to the public, many of whom do not understand the uncertainty in the data or typical plume behavior. 
\{“blank” page\} 
Printed in the United States of America

Prepared For

U.S. Department of Energy 